Prepared in cooperation with Pierce, Polk, and St. Croix Counties

\title{
Simulation of the Groundwater-Flow System in Pierce, Polk, and St. Croix Counties, Wisconsin
}

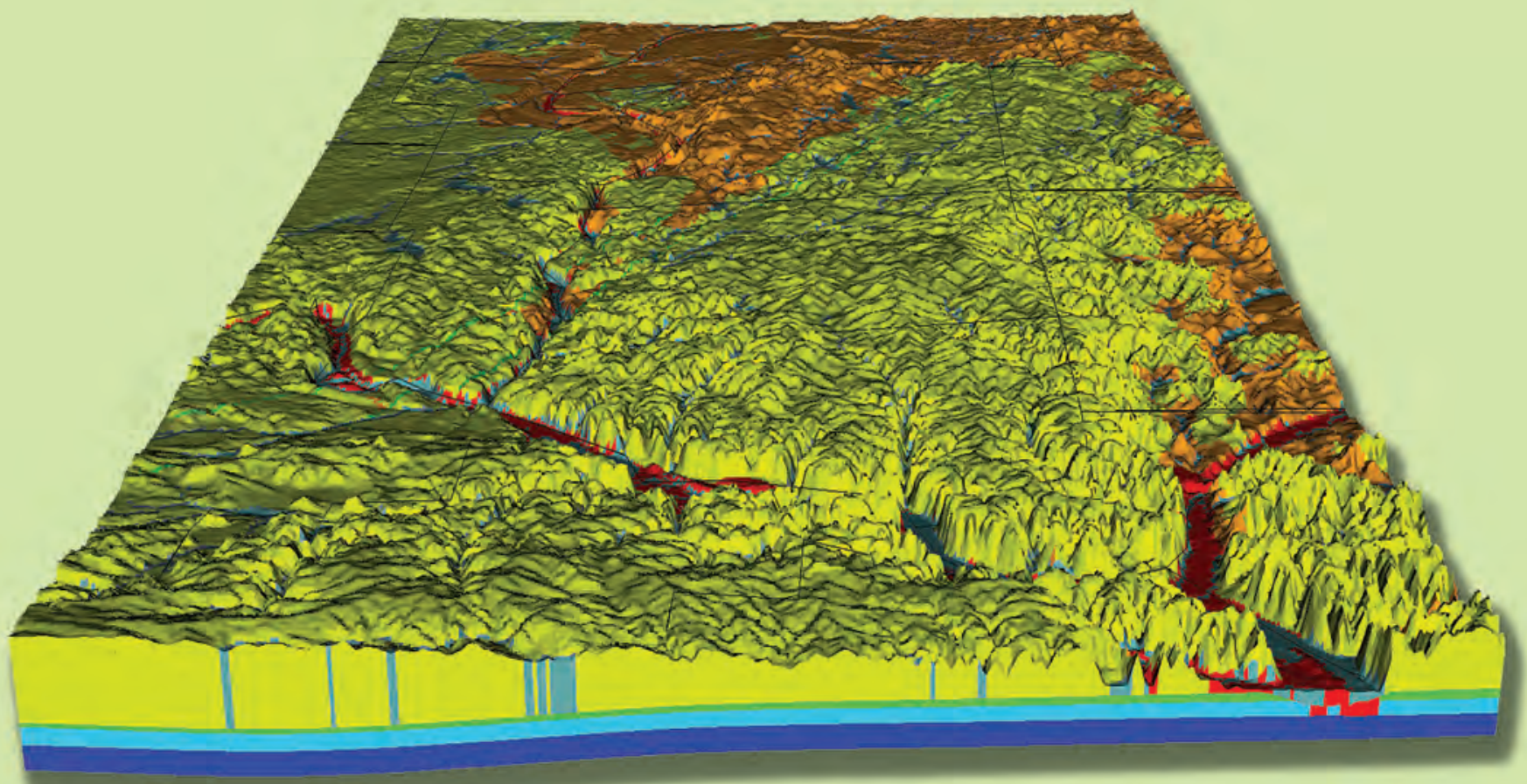

Scientific Investigations Report 2009-5056 



\title{
Simulation of the Groundwater-Flow System in Pierce, Polk, and St. Croix Counties, Wisconsin
}

\author{
By Paul F. Juckem
}

Prepared in cooperation with Pierce, Polk, and St. Croix Counties

Scientific Investigations Report 2009-5056 


\title{
U.S. Department of the Interior \\ KEN SALAZAR, Secretary
}

\author{
U.S. Geological Survey \\ Suzette M. Kimball, Acting Director
}

U.S. Geological Survey, Reston, Virginia: 2009

For more information on the USGS - the Federal source for science about the Earth, its natural and living resources, natural hazards, and the environment, visit http://www.usgs.gov or call 1-888-ASK-USGS

For an overview of USGS information products, including maps, imagery, and publications, visit http://www.usgs.gov/pubprod

To order this and other USGS information products, visit http://store.usgs.gov

Any use of trade, product, or firm names is for descriptive purposes only and does not imply endorsement by the U.S. Government.

Although this report is in the public domain, permission must be secured from the individual copyright owners to reproduce any copyrighted materials contained within this report.

Suggested citation:

Juckem, P.F., 2009, Simulation of the groundwater-flow system in Pierce, Polk, and St. Croix Counties, Wisconsin: U.S. Geological Survey Scientific Investigations Report 2009-5056, 53 p.

Cover illustration. See figure 7, page 16.

9781411324299 


\section{Contents}

Abstract

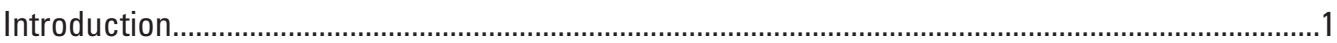

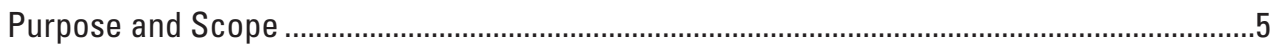

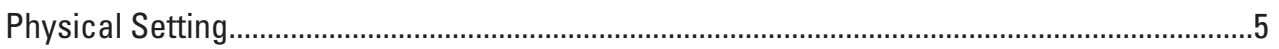

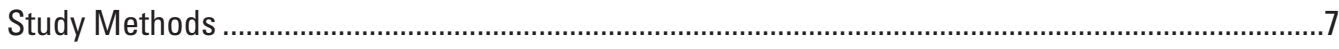

Conceptual Model of the Groundwater-Flow System ………..................................................10

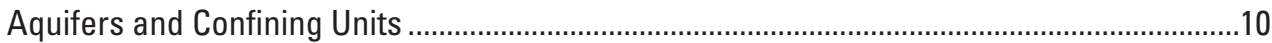

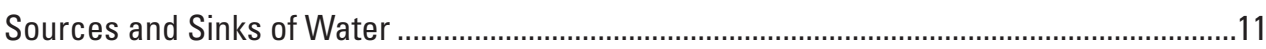

Hydrogeologic Boundaries ................................................................................................

Hydraulic Properties of the Groundwater-Flow System ..............................................................11

Hydraulic Conductivity .....................................................................................................

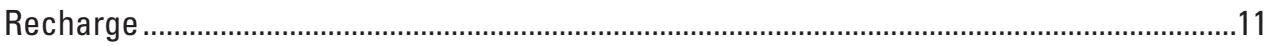

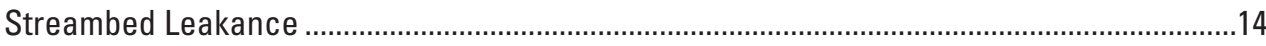

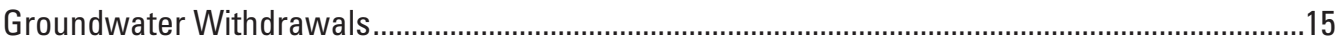

Three-Dimensional Simulation of the Regional Groundwater-Flow System ................................15

Model Construction and Assumptions .................................................................................15

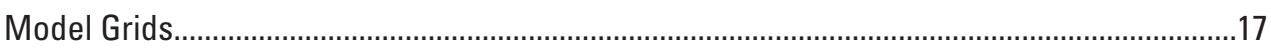

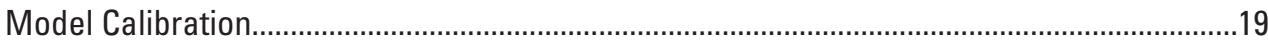

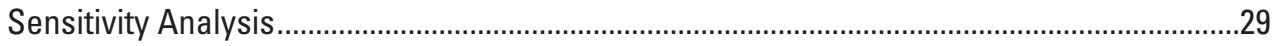

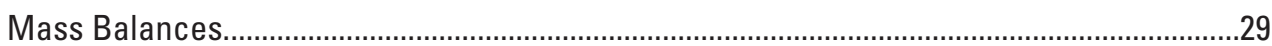

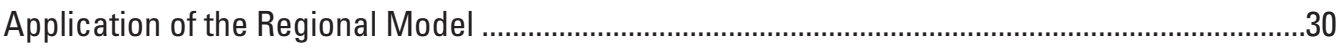

Groundwater-Flow Directions and Interaction with Surface Water........................................30

Predevelopment Conditions Compared to Present (1994-2004) Conditions. .............................33

Demonstration Simulations of Local-Scale Groundwater Flow............................................34

Telescopic Mesh Refinement .....................................................................................3

Construction and Simulation of the St. Croix County Demonstration Inset Model.........35

Results of Simulating Groundwater/Lake-Water Interaction near Twin Lakes near Roberts, St. Croix County ....................................................................37

Construction and Simulation of the Pierce County Demonstration Inset Model ............38

Results of Simulating Sources of Groundwater to Streams in Western Pierce County .............................................................................39

Construction and Simulation of the Polk County Demonstration Inset Model .................40

Results of Simulating Transient Streamflow in Osceola Creek, Polk County..........40

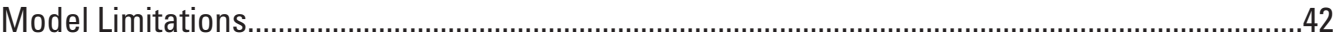

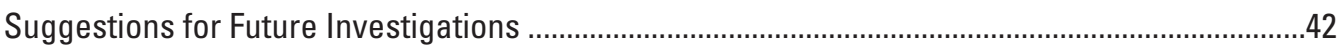

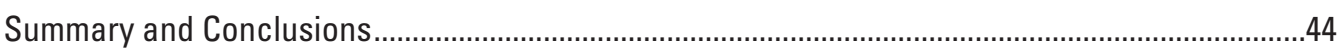

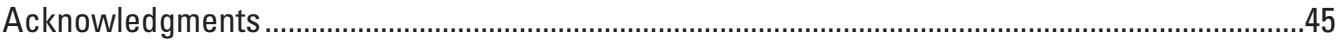

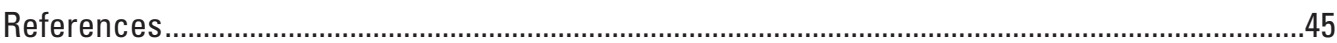

Appendix 1. Groundwater withdrawals from municipal wells in the regional groundwater-flow model ........................................................................................4

Appendix 2. Groundwater withdrawals from agricultural, industrial, and commercial wells in the regional groundwater-flow model......................................51 


\section{Figures}

1-3. Maps showing:

1. Location of the study area centered on Pierce, Polk, and St. Croix Counties, Wisconsin

2A. Location of municipal wells in and near Pierce, Polk, and St. Croix Counties, Wisconsin

$2 B$. Location of private high-capacity wells in and near Pierce, Polk, and St. Croix Counties, Wisconsin...

3. Generalized bedrock geology of Pierce, Polk, and St. Croix Counties, Wisconsin ..6

4. Geologic and hydrostratigraphic units in Pierce, Polk, and St. Croix Counties,

Wisconsin

$5 A$. Conceptual model of groundwater flow through the central and southern study area (St. Croix and Pierce Counties), Wisconsin.

$5 B$. Conceptual model of groundwater flow through the northern study area (Polk County), Wisconsin

6. Map showing extent of the analytic element model (GFLOW) and MODFLOW model grid

7. Block diagrams showing the regional MODFLOW model layers and hydraulic-conductivity zones and values

8-9. Maps showing:

8. Interpolated crystalline bedrock elevation used to form the base of the regional model (layer 4), inactive cells in layer 4, and the location of faults

9. Perimeter and internal boundary conditions, water-level-observation wells, and base-flow targets in the regional model of Pierce, Polk, and St. Croix Counties, Wisconsin.

10. Graph showing measured water levels plotted against simulated water levels for the regional model.

11-14. Maps showing:

11A. Simulated water-table elevation and water-level residuals for observation wells in the regional groundwater-flow model, layer 1

11B. Simulated water-table elevation and water-level residuals for well-construction report wells in the regional groundwater-flow model, layer 1.

12. Simulated potentiometric-surface elevation and water-level residuals for observation wells in the regional groundwater-flow model, layer 2

13. Simulated potentiometric-surface elevation and water-level residuals for observation wells in the regional groundwater-flow model, layer 4

14. Simulated water-table elevation and residuals for stream base-flow measurements in the regional groundwater-flow model, layer 1

15. Graph showing composite sensitivities computed by PEST for parameters of the regional MODFLOW model of Pierce, Polk, and St. Croix Counties, Wisconsin

16-22. Maps showing:

16. Simulated water-table elevation, particle flow paths from the water table, and groundwater/surface-water interaction in the regional groundwater-flow model, layer1

17. Simulated vertical flow directions between model layers in Pierce, Polk, and St. Croix Counties, Wisconsin 
18. Simulated water-table decline (layer 1 ) from predevelopment to present (1994-2004) water-use conditions in Pierce, Polk, and St. Croix Counties, Wisconsin

19. Simulated potentiometric-surface decline in the Mount Simon aquifer (layer 4) from predevelopment to present (1994-2004) water-use conditions in Pierce, Polk, and St. Croix Counties, Wisconsin.

20. Simulated water-table elevation and water-level residuals for the St. Croix County, Wisconsin, demonstration inset model, layer 2

21. Simulated groundwater/lake-water interaction near Twin Lakes near the village of Roberts, Wisconsin, from the St. Croix County demonstration model,layer 1

22. Simulated areas contributing groundwater recharge to rivers in western Pierce County, Wisconsin ...

23. Graph showing simulated base flow in Osceola Creek, Polk County, Wisconsin, for predevelopment and present (1994-2004) pumping conditions.

24. Map showing simulated groundwater-flow patterns near Osceola Creek, Polk County, Wisconsin

\section{Tables}

1A. Previously reported horizontal hydraulic conductivity $\left(\mathrm{K}_{\mathrm{h}}\right)$ and vertical hydraulic conductivity $\left(\mathrm{K}_{\mathrm{v}}\right)$ values, and calibrated values from the regional model

1B. Reference or source of horizontal and vertical hydraulic conductivity values reported in table $1 A$

2. Recharge rates from groundwater-flow models or other methods near the regional model area

3A. Mean error, mean absolute difference, and root mean squared difference between simulated and measured groundwater levels.

3B. Calibration results for stream base-flow targets and associated weights used for calibration with the parameter estimation program PEST

4. Mass-balance components for Pierce, Polk, and St. Croix Counties, Wisconsin, collectively and individually, and the entire model area.

5. Parameter values used for the demonstration inset models .............................................36

6. Simulated mass-balance components for Twin Lakes, St. Croix County, Wisconsin .....37 


\section{Conversion Factors and Datum}

\begin{tabular}{|c|c|c|}
\hline Multiply & By & To obtain \\
\hline \multicolumn{3}{|c|}{ Length } \\
\hline inch (in.) & 25.4 & millimeter $(\mathrm{mm})$ \\
\hline foot $(\mathrm{ft})$ & 0.3048 & meter $(\mathrm{m})$ \\
\hline mile (mi) & 1.609 & kilometer $(\mathrm{km})$ \\
\hline \multicolumn{3}{|c|}{ Area } \\
\hline acre & 0.4047 & hectare (ha) \\
\hline \multicolumn{3}{|c|}{ Flow and precipitation rate } \\
\hline inch per year (in/yr) & 25.4 & millimeter per year $(\mathrm{mm} / \mathrm{yr})$ \\
\hline foot per day (ft/d) & 0.3048 & meter per day $(\mathrm{m} / \mathrm{d})$ \\
\hline foot per year (ft/yr) & 0.3048 & meter per year (m/yr) \\
\hline cubic foot per second $\left(\mathrm{ft}^{3} / \mathrm{s}\right)$ & 0.02832 & cubic meter per second $\left(\mathrm{m}^{3} / \mathrm{s}\right)$ \\
\hline gallon per minute (gal/min) & 0.06309 & liter per second $(\mathrm{L} / \mathrm{s})$ \\
\hline million gallons per year (Mgal/yr) & 3,785 & cubic meter per year $\left(\mathrm{m}^{3} / \mathrm{yr}\right)$ \\
\hline million gallons per day (Mgal/d) & 0.04381 & cubic meter per second $\left(\mathrm{m}^{3} / \mathrm{s}\right)$ \\
\hline acre-foot per year (acre-ft/yr) & 0.001233 & cubic hectometer per year $\left(\mathrm{hm}^{3} / \mathrm{yr}\right)$ \\
\hline \multicolumn{3}{|c|}{ Hydraulic conductivity* } \\
\hline foot per day (ft/d) & 0.3048 & meter per day $(\mathrm{m} / \mathrm{d})$ \\
\hline \multicolumn{3}{|c|}{ Leakance } \\
\hline foot per day per foot $([\mathrm{ft} / \mathrm{d}] / \mathrm{ft})$ & 1 & meter per day per meter $([\mathrm{m} / \mathrm{d}] / \mathrm{m})$ \\
\hline
\end{tabular}

Vertical coordinate information is referenced to the North American Vertical Datum of 1988 (NAVD 88).

Elevation, as used in this report, refers to distance above the vertical datum.

*Hydraulic conductivity: The standard unit for hydraulic conductivity is cubic foot per day per square foot of aquifer cross-sectional area $\left(\mathrm{ft}^{3} / \mathrm{d} / \mathrm{ft}^{2}\right)$. In this report, the mathematically reduced form, foot per day ( $\mathrm{ft} / \mathrm{d})$, is used for convenience. 


\title{
Simulation of the Groundwater-Flow System in Pierce, Polk, and St. Croix Counties, Wisconsin
}

\author{
By Paul F. Juckem
}

\section{Abstract}

Groundwater is the sole source of residential water supply in Pierce, Polk, and St. Croix Counties, Wisconsin. A regional three-dimensional groundwater-flow model and three associated demonstration inset models were developed to simulate the groundwater-flow systems in the three-county area. The models were developed by the U.S. Geological Survey in cooperation with the three county governments. The objectives of the regional model of Pierce, Polk, and St. Croix Counties were to improve understanding of the groundwaterflow system and to develop a tool suitable for evaluating the effects of potential water-management programs.

The regional groundwater-flow model described in this report simulates the major hydrogeologic features of the modeled area, including bedrock and surficial aquifers, groundwater/surface-water interactions, and groundwater withdrawals from high-capacity wells. Results from the regional model indicate that about 82 percent of groundwater in the three counties is from recharge within the counties; 15 percent is from surface-water sources, consisting primarily of recirculated groundwater seepage in areas with abrupt surface-water-level changes, such as near waterfalls, dams, and the downgradient side of reservoirs and lakes; and 4 percent is from inflow across the county boundaries. Groundwater flow out of the counties is to streams ( 85 percent), outflow across county boundaries (14 percent), and pumping wells (1 percent). These results demonstrate that the primary source of groundwater withdrawn by pumping wells is water that recharges within the counties and would otherwise discharge to local streams and lakes.

Under current conditions, the St. Croix and Mississippi Rivers are groundwater discharge locations (gaining reaches) and appear to function as "fully penetrating" hydraulic boundaries such that groundwater does not cross between Wisconsin and Minnesota beneath them. Being hydraulic boundaries, however, they can change in response to water withdrawals. Tributary rivers act as "partially penetrating" hydraulic boundaries such that groundwater can flow underneath them through the deep sandstone aquifers. The model also demonstrates the effects of development on groundwater in the study area. Water-level declines since predevelopment (no withdrawal wells) are most pronounced where pumping is greatest and flow between layered aquifers is impeded by confining units or faults. The maximum simulated water-level decline is about 40 feet in the deep Mount Simon aquifer below the city of Hudson, Wisconsin.

Three inset models were extracted from the regional model to demonstrate the process and additional capabilities of the U.S. Geological Survey MODFLOW code. Although the inset models were designed to provide information about the groundwater-flow system, results from the inset models are presented for demonstration purposes only and are not sufficiently detailed or calibrated to be used for decisionmaking purposes without refinement. Simulation of groundwater/lake-water interaction around Twin Lakes near Roberts, in St. Croix County, Wisconsin, showed that groundwater represents approximately 5 to 20 percent of the overall lake-water budget. Groundwater-contributing areas to streams in western Pierce County are generally similar in size to the surface-water-contributing areas but do not necessarily correspond to the same land area. Transient streamflow simulations of Osceola Creek in Polk County demonstrate how stream base flow can be influenced not only by seasonal precipitation and recharge variability but also by systematic changes to the system, such as groundwater withdrawal from wells.

\section{Introduction}

Groundwater is the sole source of residential water supply in Pierce, Polk, and St. Croix Counties, WI (fig. 1), and it also sustains area lakes, streams, and wetlands. There are currently 29 municipal water-supply systems with 65 active wells operating in Pierce, Polk, and St. Croix Counties (fig. 2), which withdrew an average of approximately 8.2 million gallons per day (Mgal/d) from 1994 to 2004 (Appendix 1). Of the 65 active wells, 9 withdraw water from Quaternary sand and gravel aquifers, whereas the remaining 56 municipal wells withdraw water from bedrock aquifers. These aquifers are susceptible to contamination (Juckem, 2007) as indicated by local areas with high concentrations of nitrates in groundwater samples (Masarik and others, 2006). In addition, the counties are experiencing population growth because of their proximity to the Twin Cities metropolitan area in Minnesota. This growth is contributing to the conversion 


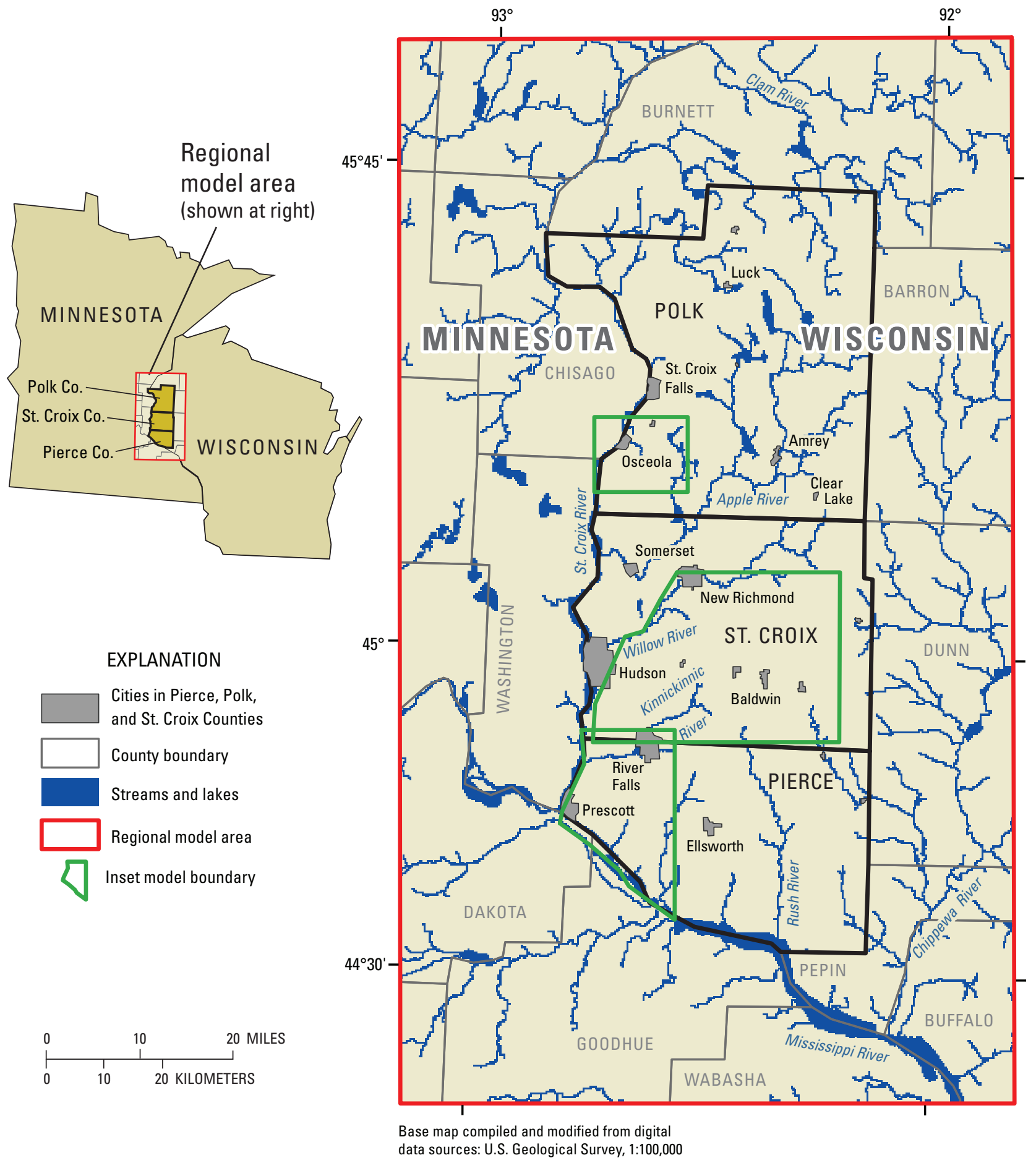

Figure 1. Location of the study area centered on Pierce, Polk, and St. Croix Counties, Wisconsin. 


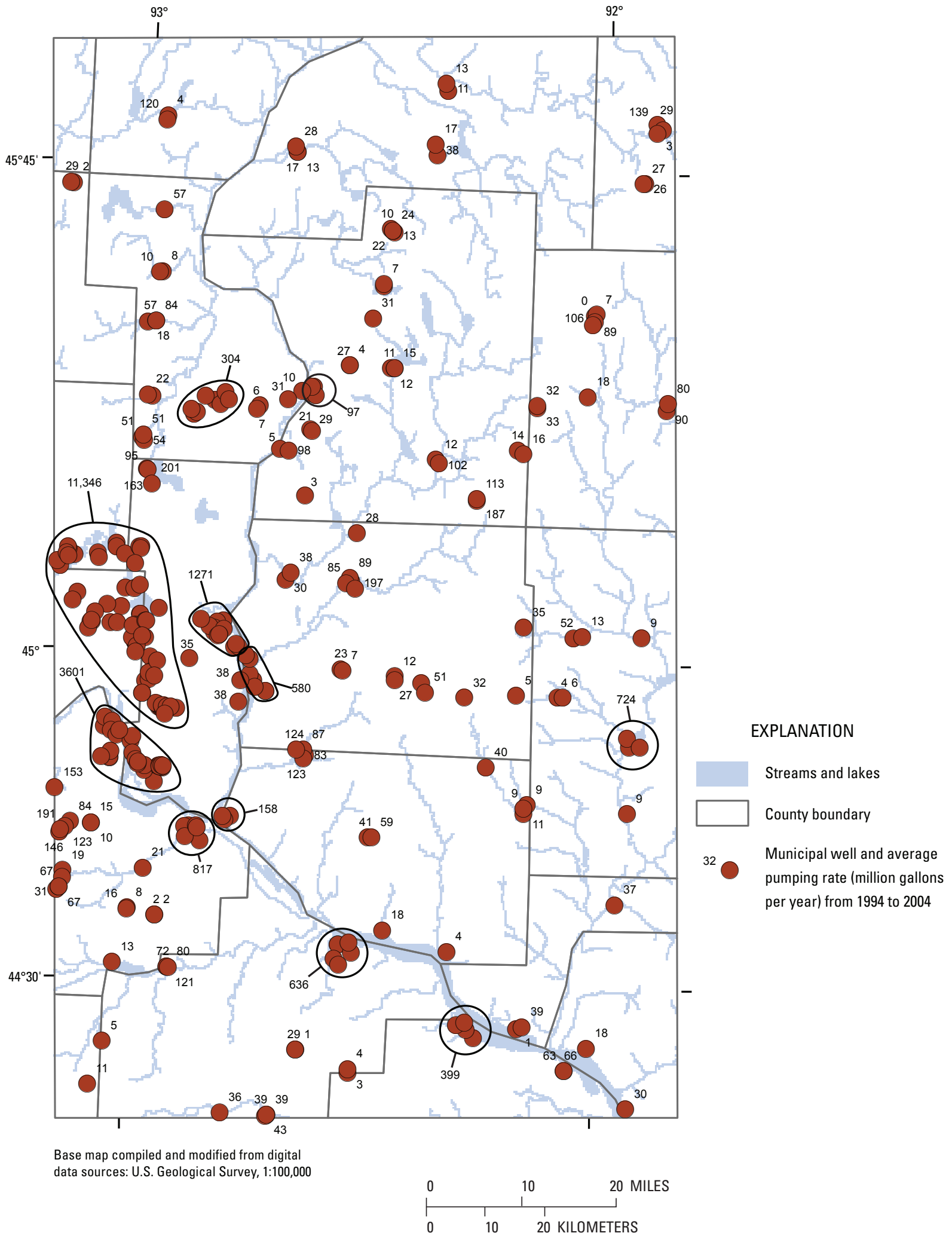

Figure 2A. Location of municipal wells in and near Pierce, Polk, and St. Croix Counties, Wisconsin. 


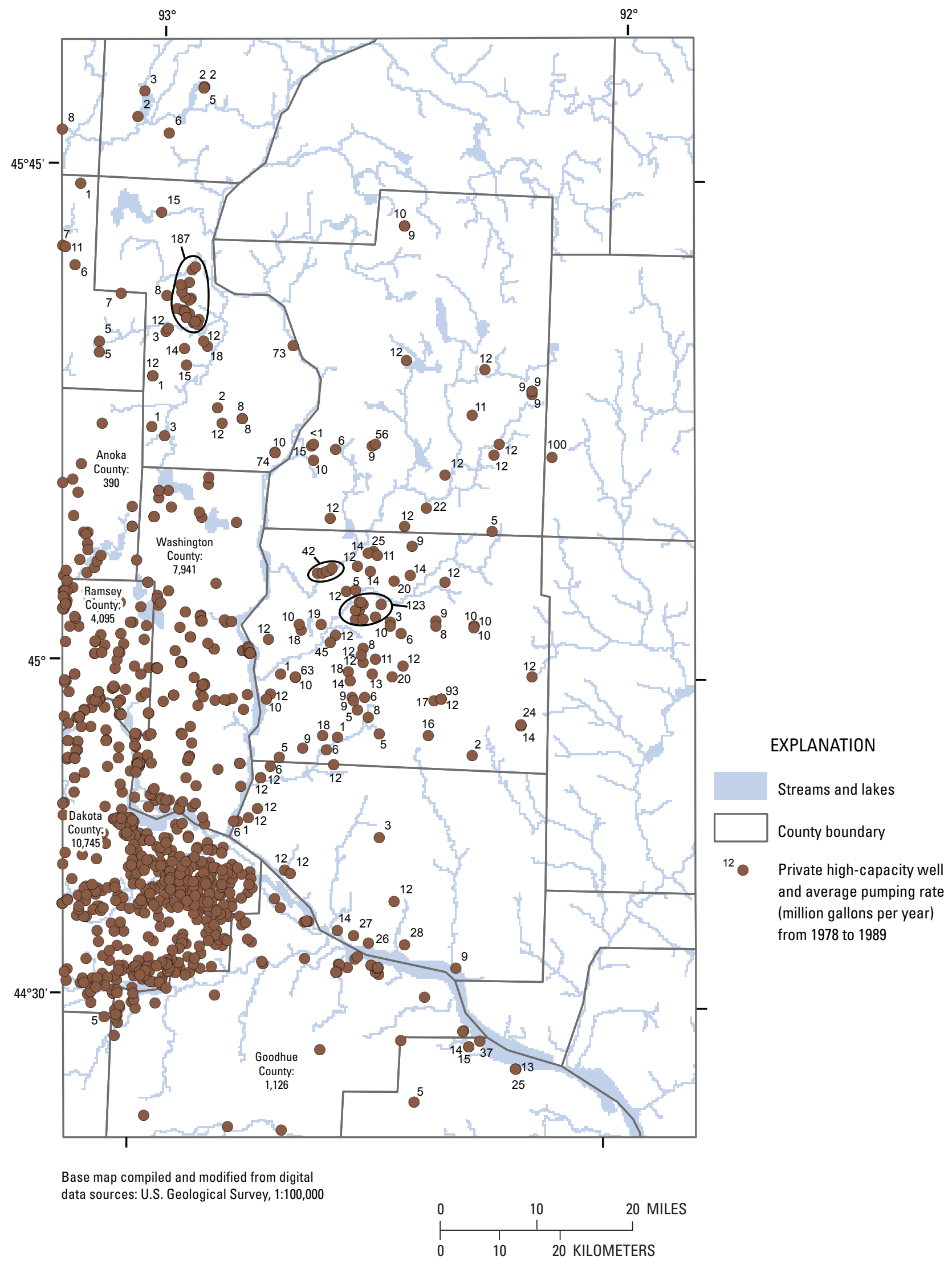

Figure 2B. Location of private high-capacity wells in and near Pierce, Polk, and St. Croix Counties, Wisconsin. 
of some cropland to low- and high-density residential and commercial development. Although groundwater is widely recognized as an important drinking-water source, it also sustains surface-water features such as streams and wetlands. Urban and county planners are faced with decisions in which the need for increased groundwater withdrawals needs to be balanced with maintaining the quantity and quality of groundwater-supported surface-water resources, such as trout streams. Managing and protecting the ground- and surface-water (or "hydrologic") resources requires a basic understanding of hydrologic systems. Information about the groundwater system — such as the extent of aquifer units, their water-bearing properties, and their recharge and discharge areas-is helpful in assessing the susceptibility of water supplies to overuse and changes in recharge or contamination.

The regional groundwater study described in this report was conducted by the U.S. Geological Survey (USGS) in cooperation with Pierce, Polk, and St. Croix Counties, WI. Data from topographic and geologic maps, well-construction reports (WCRs; Wisconsin Department of Natural Resources, 2003), water-level measurements, and surface-water features were synthesized to produce a conceptual model of aquifer units and the regional groundwater-flow system. Although the data and maps produced in a regional study provide basic hydrogeologic information for water-resource management, this information also is the basis for constructing groundwaterflow models. These models are mathematical representations of the natural system that can be used to simulate how water flows through the system and how the system will react to stress (such as increased pumping from wells or decreased recharge below impervious areas).

Previous work in and around the three-county area included regional two-dimensional groundwater-flow models (Feinstein and others, 2005; Muldoon and others, 2007) and characterization of local groundwater flow at several contamination sites, including one for which a groundwater-flow model was constructed (Delta Environmental Consultants, written commun., 1997). The modeling described in this report differs from the previous work in the following ways. It is larger in extent, incorporating all of Pierce, Polk, and St. Croix Counties and parts of 17 surrounding counties in Wisconsin and Minnesota. It also includes extensive geologic and hydrologic data that facilitate the conceptualization and parameterization of the regional groundwater-flow system through use of multiple layers to simulate three-dimensional flow. Moreover, the regional model was designed to function as a framework for evaluating groundwater flow at multiple scales by extracting inset models, as demonstrated in this report. The resulting regional model can be used to identify major areas of groundwater recharge and discharge, and estimate the amount of groundwater discharge to surfacewater bodies. The model also can be used in a "what if" capacity to simulate effects of groundwater withdrawals, both existing and potential, and the effects of proposed water-management programs.

\section{Purpose and Scope}

This report presents the results of a regional hydrologic investigation in Pierce, Polk, and St. Croix Counties., WI. The purpose of the study was to (1) improve understanding of the groundwater-flow system and its relation to surface waters, (2) develop a groundwater-flow model for use on an ongoing basis by water-resource managers, and (3) demonstrate use of the regional model as a framework for extracting local inset models to simulate groundwater flow and groundwater/ surface-water interactions at local scales. The third objective was accomplished by constructing one inset model in each of the three counties to demonstrate additional capabilities of groundwater-flow models.

The scope of this study is regional, and was a cooperative effort that included Pierce, Polk, and St. Croix Counties and the USGS. This report describes (1) the conceptualization of the groundwater-flow system, (2) the methods used in simulating groundwater flow, (3) the calibrated model parameters and sensitivity, (4) interpretation of simulated results, (5) demonstration of inset modeling in each county, and (6) limitations of the models.

The regional model includes the entire area of Pierce, Polk, and St. Croix Counties, parts of 6 adjacent counties in west-central Wisconsin, and parts of 11 counties in Minnesota (fig. 1). The three demonstration-inset models include an area near the village of Osceola in Polk County, a large area in St. Croix County extending from Hudson to Woodville, and the area west of the town of Trimbelle in Pierce County.

\section{Physical Setting}

Pierce, Polk, and St. Croix Counties are in the St. Croix and Chippewa River watersheds of west-central Wisconsin (fig. 1). The area receives about 32 inches (in.) of precipitation annually, with temperatures that typically range from lows around zero degrees Fahrenheit $\left({ }^{\circ} \mathrm{F}\right)$ in the winter to highs around $85^{\circ} \mathrm{F}$ in the summer (Natural Resources Conservation Service, 2002). Land cover in the three counties is dominated by agriculture and grasslands, but substantial forested and urban acreage also is included (Wisconsin Department of Natural Resources, 1998).

Most of Polk County is in the Central Plain physiographic region of Wisconsin (described by Martin, 1965), which has generally low topographic relief and thick glacial deposits. St. Croix and Pierce Counties are part of the Western Upland (Martin, 1965), which is characterized by broad uplands that are interrupted by distinct valleys where erosion has removed the relatively thin glacial deposits and much of the thick sequence of underlying sedimentary rock. Most streams in the Central Plain region of Polk County derive base flow (the portion of total streamflow that is derived from groundwater discharge) from the glacial aquifer that overlies relatively thin sedimentary bedrock. The glacial deposits are composed primarily of tills and sands of variable thickness (Johnson, 
2000). In central Polk County, the glacial deposits lie directly on a ridge of low-permeability crystalline bedrock (locally referred to as Trap Rock). Glacial deposits are similar in St. Croix and Pierce Counties (Baker, 1984; Kostka and others, 2004), yet most of the base flow in streams of the Western Upland region in St. Croix and Pierce Counties is derived primarily from permeable bedrock consisting of alternating layers of dolomite (limestone), sandstone, and shale.

Impermeable, Precambrian crystalline bedrock (primarily granite and basalt) underlies all sedimentary rocks in the three counties (figs. 3 and 4). Alternating layers of sandstone, shale, and dolomite of Cambrian and Ordovician age overlie the crystalline rock. Detailed maps and descriptions of the geology of the region have been assembled by Mudrey and others (1987), Brown (1988), Mossler (1992), Young (1992),

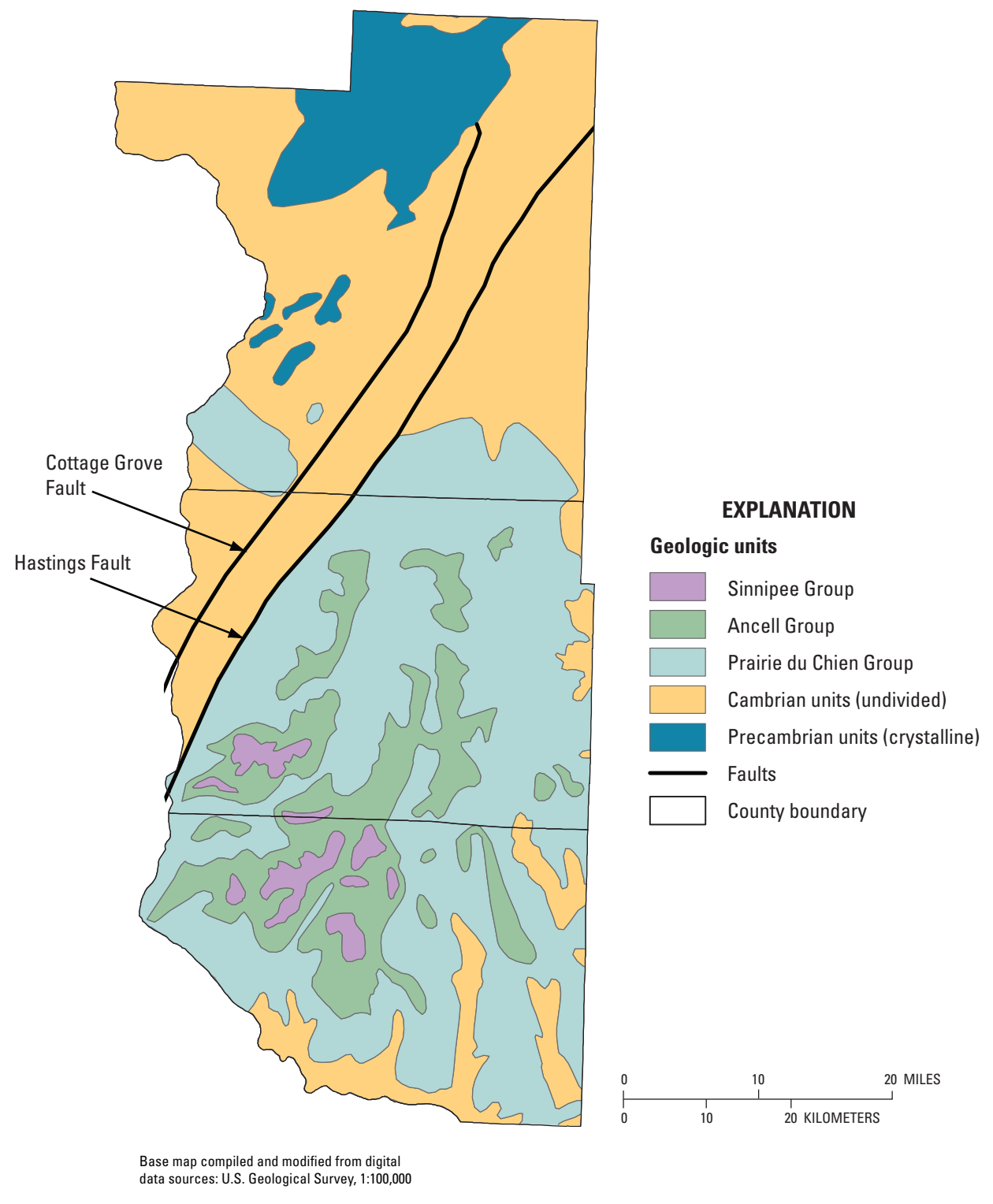

Figure 3. Generalized bedrock geology of Pierce, Polk, and St. Croix Counties, Wisconsin (modified from Cannon and others, 1997).
Johnson (2000), Runkel and others (2003), Kostka and others (2004), LePain and others (2005), LePain (2006), Runkel and others (2006), Tipping and others (2006), Cobb (2007), and Evans and others (2007). A summary of the regional geology from these sources follows. For consistency, the stratigraphic nomenclature and ages of the units used in this report are those of the Wisconsin Geological and Natural History Survey, following the nomenclature of Ostrom (1967) and Mickelson and others (1984).

Rocks of Cambrian age (490 to 523 million years) include, from oldest to youngest (and deepest to shallowest), the Mount Simon Formation, Eau Claire Formation, Wonewoc Formation, Tunnel City Group, and Trempealeau Group (St. Lawrence and Jordan Formations) (fig. 4). The Mount Simon Formation is a medium- to coarse-grained sandstone with some shale and is about 250 feet (ft) thick in the threecounty study area. The overlying Eau Claire Formation is composed of laterally extensive layers of very fine- to fine-grained sandstone and silty shale with a total thickness of about $100 \mathrm{ft}$. The Wonewoc Formation is a clean, well-sorted, medium- to coarse-grained quartzose sandstone, approximately $75 \mathrm{ft}$ thick. Above the Wonewoc, the approximately 150 -ft-thick Tunnel City Group is composed of interbedded layers of shale and poorly sorted, glauconitic, very fine- to coarse-grained sandstone. The uppermost Cambrian unit is the Trempealeau Group (about $100 \mathrm{ft}$ thick), which consists of very fine-grained dolomitic siltstone and silty glauconitic dolomite in the St. Lawrence Formation and clean, fine- to coarse-grained quartzose sandstone in the Jordan Formation. Rocks of Ordovician age (443 to 490 million years) overlie the Cambrian rocks and consist of the Prairie du Chien Group, the Ancell Group, and the Sinnipee Group, in order from oldest to youngest (fig. 4). The Prairie du Chien Group consists of fine- to medium- grained sandstone and sandy dolomite and is about $200 \mathrm{ft}$ thick where it is not eroded below glacial deposits. The Prairie du Chien Group is susceptible to fracturing and weathering, which can produce solution cavities and conduits associated with karst aquifers. The Ancell Group is a 


GEOLOGIC
UNITS
(Young, 1992)

Figure 4. Geologic and hydrostratigraphic units in Pierce, Polk, and St. Croix Counties, Wisconsin. The regional model consolidates all bedrock units above the Wonewoc aquifer into one hydrostratigraphic unit (upper bedrock aquifer).
USGS REGIONAL MODEL UNITS

(this report)

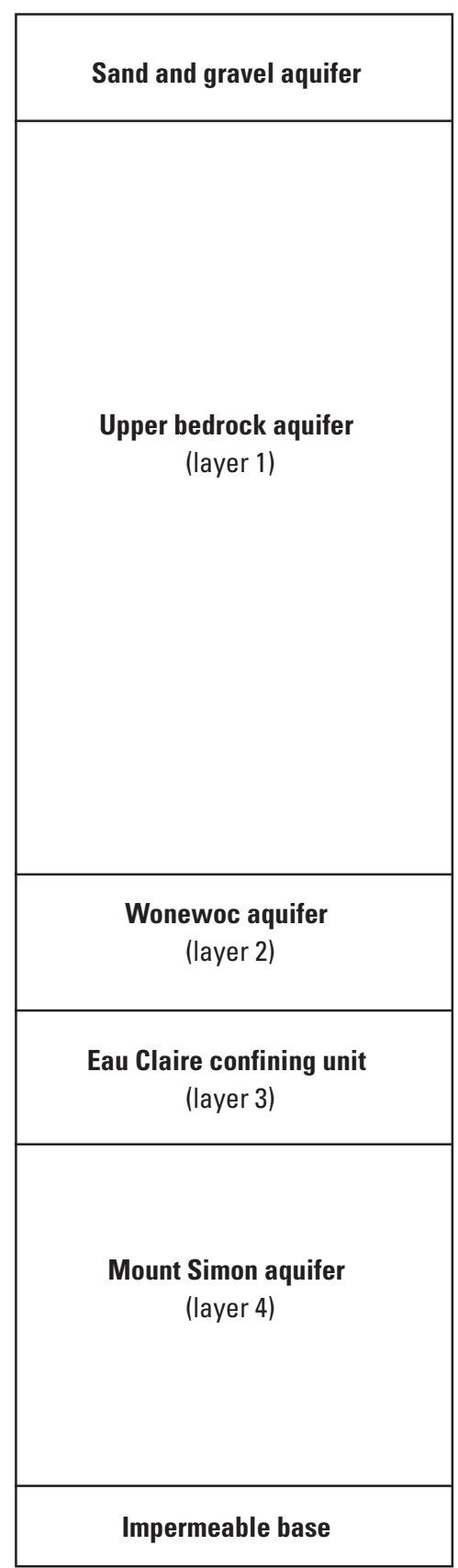

fine- to medium-grained, well-sorted sandstone (about $75 \mathrm{ft}$ thick where present) that is overlain by the thin-bedded dolomites of the Sinnipee Group (as much as about $20 \mathrm{ft}$ thick where present). The Ancell and Sinnipee Groups have been extensively eroded in the three counties and occur only in upland ridges and mounds in Pierce and St. Croix Counties.

\section{Study Methods}

Before construction of the threedimensional ground-water-flow models, a conceptual model of the regional system (figs. 5A, $B$ ) was developed on the basis of previously collected data. Using the methodology described by Hunt, Anderson,

In some locations, the characteristics of the sedimentary rocks have been altered. Sedimentary rocks are vertically offset by hundreds of feet along two regional faults (fig. 3) and by tens of feet along smaller mapped and unmapped faults throughout the study area. The regional Hastings and Cottage Grove Faults extend through all of the sedimentary rock and place rocks of different formations adjacent to one another (Mudrey and others, 1987; LePain, 2006). The internal structure of faults in the study rea is not well understood, nor is the effect faults on groundwater-flow patterns. ch outside of the study area suggests that faults generally are composed of a thin internal fine-grained core and a surrounding damage zone in which the native rocks are fractured (Caine and others, 1996; Rawling and others, 2001).

Fractures in the Ordovician dolomite rocks throughout the study area can increase the potential for dissolution of these carbonate rocks and have led to the formation of cavities, caves, and sinkholes in the study area. These features form a "triple porosity system" (Cobb, 2007) more generally referred to as a "karst aquifer" through which large quantities of groundwater can flow rapidly over hundreds to thousands of feet (Runkel and others, 2003; Tipping and others, 2006; Cobb, 2007). The largest conduits generally occur in the uppermost sections of the Prairie du Chien Group, and flow through these conduits generally is controlled by the size and degree of connection among individual conduits or conduit zones (Runkel and others, 2003; Tipping and others, 2006; Cobb, 2007). and Kelson (1998) and Hunt, Kelson, and Anderson (1998), a two-dimensional analytic-element groundwater-flow model (GFLOW code, Haitjema, 1995) developed by Feinstein and others (2005) for the St. Croix River Basin was modified and used as a simplified screening model to quickly test the conceptual model and derive hydrologic boundaries for the 


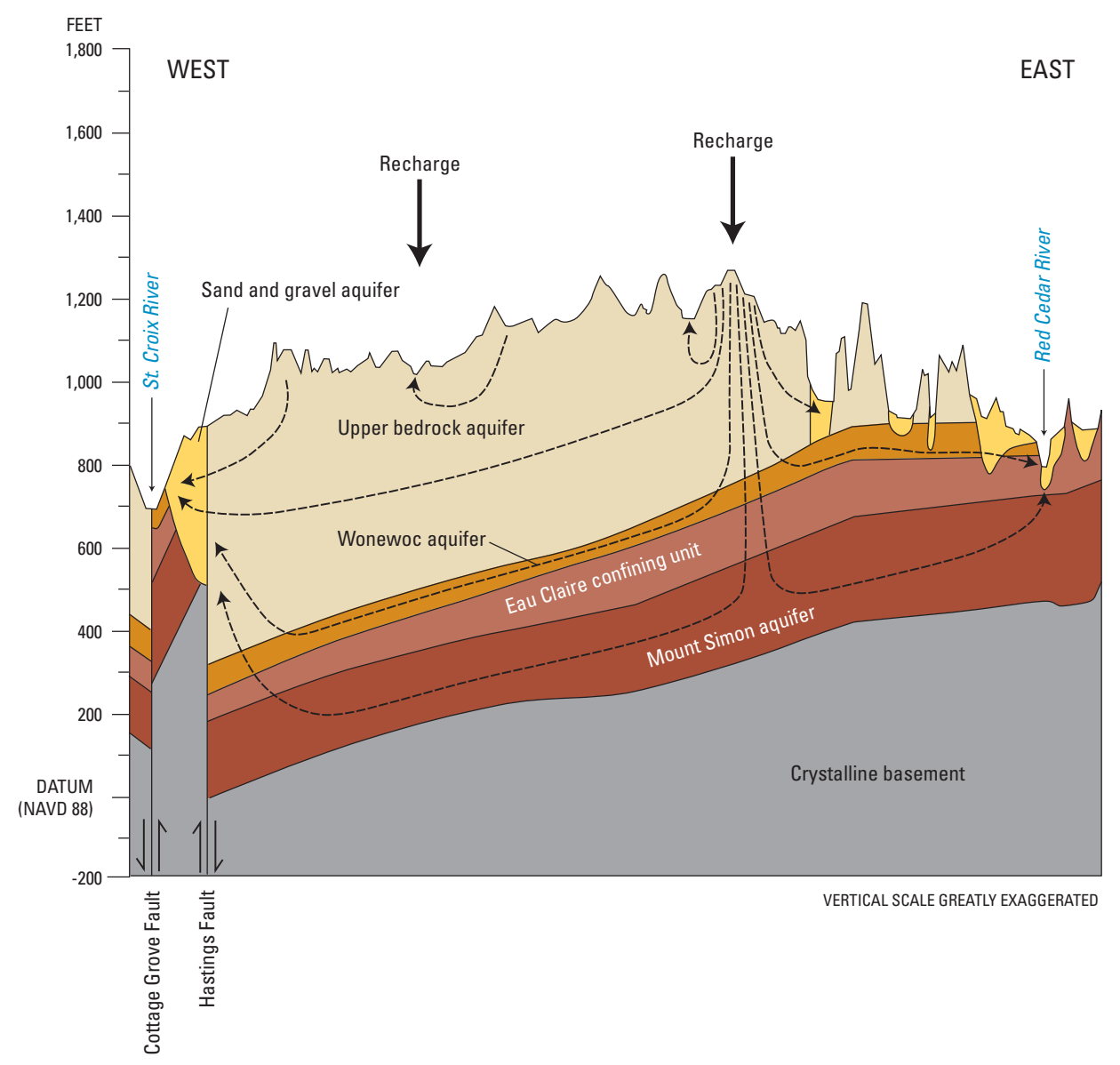

Figure 5A. Conceptual model of groundwater flow through the central and southern study area (St. Croix and Pierce Counties), Wisconsin (modified from Kammerer and others, 1998). Note: Some groundwater flow is perpendicular to the cross section (north and south).

Figure 5B. Conceptual model of groundwater flow through the northern study area (Polk County), Wisconsin (modified from Kammerer and others, 1998). Note: Some groundwater flow is perpendicular to the cross section (north and south).

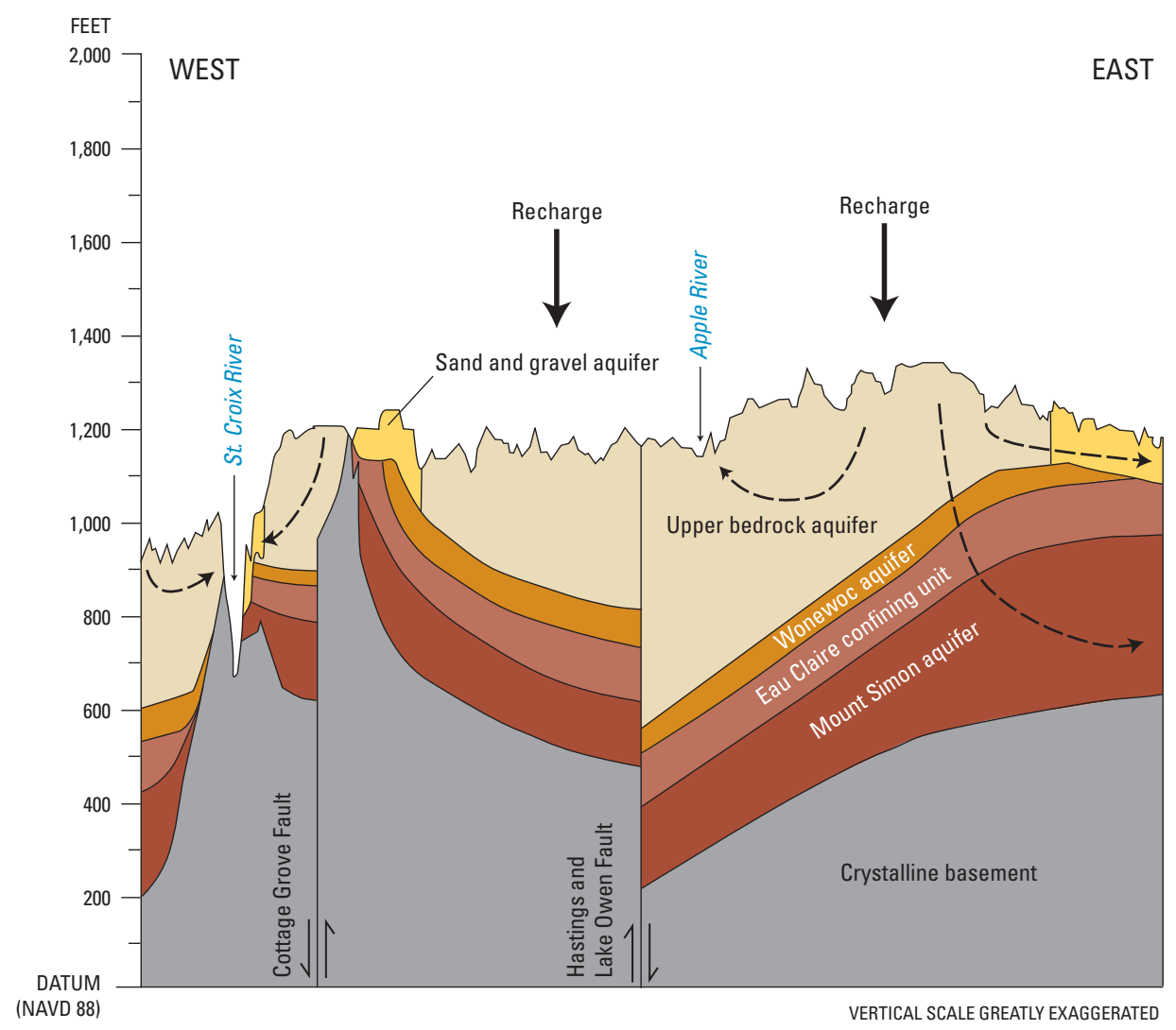


three-dimensional regional model (fig. 6). A complete description of analytic-element modeling is beyond the scope of this report; a brief overview is given below. Strack (1989) and Haitjema (1995) provide detailed discussions of the analyticelement method.
Analytic-element modeling assumes an aquifer of infinite extent. The problem domain does not require a grid or involve interpolation between cells. To construct an analytic-element model, features important to groundwater flow (for example, wells) and surface-water bodies are entered as mathematical
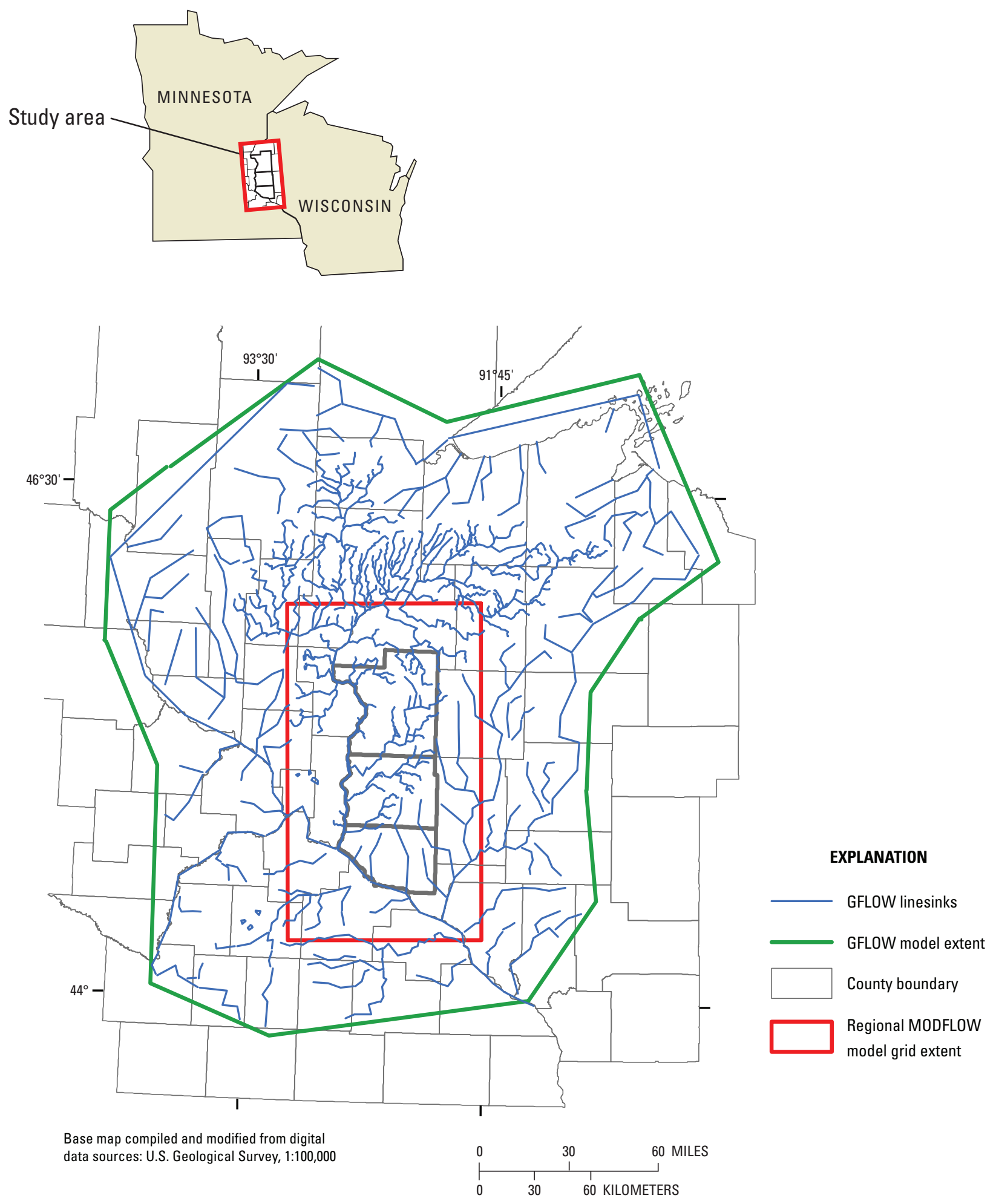

Figure 6. Extent of the analytic element model (GFLOW) and MODFLOW model grid. Uniform grid spacing is 348 columns, 604 rows (not shown). 
elements or strings of elements. The amount of detail specified for each feature depends on its distance from the area of interest. Each element corresponds to an analytic solution, and these solutions are superposed or added together in the model to arrive at a solution for the groundwater-flow system. Because the solution is not confined to a grid, as it is in the finite-difference method, groundwater levels and flows can be computed anywhere in the model domain without nodal averaging. In GFLOW modeling, the analytic elements are two-dimensional and are used only to simulate steady-state conditions (that is, groundwater levels do not vary with time). Comparisons of analytic element to finite-difference numerical modeling techniques are given in Hunt and Krohelski (1996); Hunt, Anderson, and Kelson (1998); and Hunt, Kelson, and Anderson (1998).

MODFLOW-2000 (Harbaugh and others, 2000), a USGS block-centered, finite-difference code, was used to simulate the three-dimensional flow system in the regional and inset models. MODFLOW requires input arrays (gridded data) that describe hydraulic parameters such as hydraulic conductivity and recharge, top and bottom elevation of aquifers, and boundary conditions. Detailed discussions of finite-difference methods, MODFLOW input requirements, and theory are provided by McDonald and Harbaugh (1988), Anderson and Woessner (1992), and Harbaugh and others (2000). Three steps were used to create the input arrays required by MODFLOW. First, geographic information system (GIS) coverages of aquifer top and bottom elevations were developed from data in well logs and published reports (Mossler, 1983; Mandle and Kontis, 1992; Young, 1992; Wisconsin Geological and Natural History Survey, 2003). Second, these GIS coverages were intersected with the model grid and imported into Groundwater Vistas (Rumbaugh and Rumbaugh, 2007), a groundwater modeling preprocessor. Third, boundary conditions at the model perimeter were extracted directly from the analytic-element model. The details of the technique are described in more detail by Hunt, Kelson, and Anderson (1998).

Calibration of the regional MODFLOW model was aided by use of parameter-estimation techniques included in the code PEST (Doherty, 2004). The primary benefit of parameter estimation is the ability to automatically calculate parameter values (for example, hydraulic conductivity and recharge) that are a quantified best fit between simulated model output and observed data (for example, groundwater levels and streamflows). Other benefits also include quantification of the quality of the calibration, parameter correlation (for example, hydraulic conductivity and recharge), and parameter sensitivity.

\section{Conceptual Model of the Groundwater- Flow System}

Before simulating a groundwater system, a conceptualization of the system is essential as a basis for model development. The conceptualization is a necessary simplification of the natural system because inclusion of all of the complexities of the natural system into a computer model is not feasible given the existing knowledge of the subsurface and current computer capabilities. Steps in the development of the conceptual model include (1) definition of aquifers and confining units, (2) identification of sources and sinks of water, and (3) identification and delineation of hydrologic boundaries encompassing the area of interest. The first two of these steps were accomplished by review and interpretation of existing and new geologic and hydrogeologic data. The third step was accomplished by use of a screening model.

\section{Aquifers and Confining Units}

Four regionally extensive aquifers and two regionally extensive confining units are present in the three-county area, based on the hydrogeologic units (fig. 4) identified for west-central Wisconsin (Young, 1992) and south-eastern Minnesota (Delin and Woodward, 1984). The conceptual model of the groundwater-flow system is shown in figure 5 . The vertical scale of the conceptual-model diagrams has been greatly exaggerated to illustrate the geologic units; regional flow through the aquifers is primarily horizontal.

A sand and gravel aquifer is made up of unconsolidated glacial and alluvial materials overlying the bedrock. Except in narrow alluvial valleys and the broader St. Croix and Mississippi River Valleys, the sand and gravel aquifer in the model is limited to the northern part of the area and is simulated in the regional model only where the upper bedrock aquifer is absent. The unconsolidated deposits that form this aquifer generally are 50 to $200 \mathrm{ft}$ thick in Polk County and less than $50 \mathrm{ft}$ thick in much of St. Croix and Pierce Counties where the deposits commonly are above the regional water table (Trotta and Cotter, 1973; Borman, 1976). The upper bedrock aquifer underlies the sand and gravel aquifer. The upper bedrock is made up of sandstone and dolomite and includes the Sinnipee and Ancell Groups, where present, and the Prairie du Chien, Trempealeau, and Tunnel City Groups. Several subregional confining units are identified within the upper bedrock aquifer, including the base of the Tunnel City Group. This confining unit is largely absent in the St. Croix and Mississippi River Valleys and tributary valleys to the Chippewa River, but it forms the first of two confining units where it is present in the regional model. The Wonewoc Formation underlies the shaly base of the upper aquifer (the base of the Tunnel City confining unit) and forms the thin Wonewoc aquifer. Several shaly facies within the Eau Claire Formation underlie the Wonewoc aquifer and form the Eau Claire confining unit. The Mount Simon Formation forms the lower bedrock aquifer that overlies Precambrian crystalline basement rock. The Precambrian crystalline basement rock is assumed to be impermeable and forms the lower boundary of the groundwater-flow system. Most municipal and private water-supply systems use the upper bedrock aquifer or the sand and gravel aquifer where it is sufficiently thick. 


\section{Sources and Sinks of Water}

Water enters the groundwater-flow system as recharge to the water table. Recharge occurs over the entire regional model area, except where groundwater discharges to streams. Groundwater-flow paths may be local or regional. As shown in figure 5, the upper bedrock aquifer includes both local and regional flow paths, whereas flow through the underlying Wonewoc and Mount Simon aquifers tends to occur primarily along long, regional flow paths. Some recharging water moves downward to the sand and gravel or upper bedrock aquifer, travels a short horizontal distance, and discharges to a stream or wetland. Recharge may also move downward through the confining units into the Wonewoc and Mount Simon bedrock aquifers. In areas where the confining units are absent, recharge may move through the sand and gravel aquifer directly to the Wonewoc or Mount Simon bedrock aquifers. Because of the conductive nature of the Mount Simon bedrock aquifer and the nearly impermeable Precambrian rock forming the lower boundary of the system, flow paths in the Mount Simon bedrock aquifer are primarily horizontal on the regional scale. Pumping wells, a locally important sink of groundwater, can be open to the sand and gravel aquifer (for example, in municipalities underlain by glacial deposits, such as the cities of Frederic and Balsam Lake) or to the bedrock aquifers (for example, in municipalities on the bedrock uplands, such as the cities of New Richmond, Hudson, and Ellsworth). Pumping associated with the wells captures part of the groundwater that under predevelopment conditions would have discharged to streams and wetlands. In areas of large groundwater withdrawals, especially in surficial aquifers, streams that otherwise would capture groundwater may instead locally recharge the groundwater system.

\section{Hydrogeologic Boundaries}

The analytic-element screening model developed by Feinstein and others (2006), using the code GFLOW (Haitjema, 1995), was extended by about $50 \mathrm{mi}$ to the east, south, and west of the mouth of the St. Croix River at Prescott, WI, so that the simulated area extended well beyond the three-county area of interest (fig. 6). The screening model is a simplified representation of the natural system because (1) the flow system is assumed to be two-dimensional, for which vertical components of flow and the three-dimensional nature of the geologic deposits are ignored, (2) surface-water/ groundwater interactions are simulated by means of coarse representations, and (3) the system is at steady state (that is, water levels are not changing over time). Although the advantage of such simplification is that the model can be constructed with minimal time and data, the screening model may not generally be suitable for extensive use in land-use planning or other applications because of the limitations associated with these simplifications. The screening model is able to serve, however, as a foundation upon which to build the more complex, three-dimensional regional MODFLOW model. Flux-specified boundary conditions were extracted from the GFLOW model (Haitjema 1995; Hunt, Kelson, and Anderson 1998) as input for the well (WEL) package in MODFLOW. The extracted extents (fig. 6) were designed such that the MODFLOW model boundaries were distant from the area of interest (Pierce, Polk, and St. Croix Counties). The extracted extents include parts of Minnesota to allow direct simulation of potential underflow beneath the St. Croix River, as implied by Schoenberg $(1984,1990)$ and Wuolo (Ray Wuolo, Barr Engineering, written commun., 2005).

\section{Hydraulic Properties of the Groundwater-Flow System}

Initial estimates of hydraulic conductivity, recharge, and streambed leakance for the three-dimensional MODFLOW groundwater-flow model were based on existing geologic and hydrologic data. The following is a brief description of these estimates.

\section{Hydraulic Conductivity}

Horizontal and vertical hydraulic conductivities of the geologic units in the area have been estimated by others (table 1) through the use of specific-capacity tests, standard and discrete-interval aquifer tests, and hydrogeologic modeling. Horizontal hydraulic conductivities of the sand and gravel aquifer are reported to range from 7 to 670 feet per day (ft/d). Measured horizontal hydraulic conductivities in the bedrock aquifers typically are lower than those in the sand and gravel aquifer, with reported values ranging from 0.06 to $100 \mathrm{ft} / \mathrm{d}$. Vertical hydraulic conductivities in the sand and gravel aquifer and the bedrock aquifer generally are 1 to 7 orders of magnitude lower than the corresponding estimates of horizontal hydraulic conductivity (table 1). Although these ranges are useful for characterizing the system, the model requires specific values for the hydraulic-conductivity variation in the system. Thus, values associated with zones of locally uniform hydraulic conductivity were treated as calibration parameters. Final values used in the modeling described here were determined by use of PEST (Doherty, 2004) and then compared to the range of available measurements and estimates.

\section{Recharge}

Rates of recharge are variable because of differing soil percolation rates, slope, and relative topographic position, among other factors. This spatial variability is difficult to estimate and was of limited significance for regional groundwater-flow simulations in a similar setting in southwest Wisconsin (Hunt and others, 2003); thus, an average recharge 
Table 1A. Previously reported horizontal hydraulic conductivity $\left(\mathrm{K}_{\mathrm{h}}\right)$ and vertical hydraulic conductivity $\left(\mathrm{K}_{\mathrm{v}}\right)$ values, and calibrated values from the regional model.

$[\mathrm{ft} / \mathrm{d}$, foot per day; <, less than. Reference and source codes listed in table $1 B]$

\begin{tabular}{|c|c|c|c|c|c|}
\hline \multirow{2}{*}{\multicolumn{2}{|c|}{ Hydrogeologic unit }} & \multicolumn{2}{|c|}{ Hydraulic conductivity } & \multirow[b]{2}{*}{$\begin{array}{l}\text { Reference or } \\
\text { source code }\end{array}$} & \multirow{2}{*}{$\begin{array}{c}\text { Calibrated } \\
\text { value } \\
\text { (ft/d) }\end{array}$} \\
\hline & & Type & $\begin{array}{c}\text { Reference value } \\
\text { (ft/d) }\end{array}$ & & \\
\hline \multicolumn{6}{|c|}{ Horizontal hydraulic conductivity } \\
\hline \multirow{6}{*}{\multicolumn{2}{|c|}{ Sand and gravel aquifer }} & Simulated value & 12.5 & A & \multirow{6}{*}{90} \\
\hline & & Measured range & $7-670$ & $\mathrm{~B}$ & \\
\hline & & Simulated values & $40-420$ & $\mathrm{D}$ & \\
\hline & & Simulated values & $40-120$ & $\mathrm{E}$ & \\
\hline & & Geometric mean of measurements & 73.3 & $\mathrm{~L}$ & \\
\hline & & Measured range & $13-272$ & $\mathrm{~L}$ & \\
\hline \multirow{12}{*}{$\begin{array}{l}\text { Upper } \\
\text { bedrock } \\
\text { aquifer }\end{array}$} & \multirow{6}{*}{$\begin{array}{l}\text { Ancell- } \\
\text { Prairie du Chien- } \\
\text { Jordan aquifer }\end{array}$} & Simulated values & $4.3-81$ & A & \multirow{12}{*}{23} \\
\hline & & Simulated value & 10 & $\mathrm{E}$ & \\
\hline & & Measured range & $3.3-67$ & $\mathrm{G}$ & \\
\hline & & Range in average of measurements & $15.9-33.5$ & $\mathrm{~J}$ & \\
\hline & & Measured range & $0.1-100$ & $\mathrm{~K}$ & \\
\hline & & Measured range & $5-26$ & $\mathrm{~N}$ & \\
\hline & \multirow{6}{*}{$\begin{array}{l}\text { St. Lawrence-- } \\
\text { Tunnel City } \\
\text { confining unit }\end{array}$} & Simulated values & $0.35-4.3$ & A & \\
\hline & & Simulated value & 2.5 & $\mathrm{E}$ & \\
\hline & & Measured range & $0.1-2$ & $\mathrm{H}$ & \\
\hline & & Measured range & $<0.06-7.7$ & I & \\
\hline & & Range in average of measurements & $5.9-27.8$ & $\mathrm{~J}$ & \\
\hline & & Measured range & $1.3-20$ & $\mathrm{~N}$ & \\
\hline \multirow{8}{*}{\multicolumn{2}{|c|}{ Wonewoc aquifer }} & Simulated value & 12.2 & A & \multirow{8}{*}{11} \\
\hline & & Simulated value & 12 & $\mathrm{E}$ & \\
\hline & & Measured range & $4-83$ & $\mathrm{G}$ & \\
\hline & & Measured range & $1-4$ & $\mathrm{H}$ & \\
\hline & & Measured range & $1.7-8.2$ & I & \\
\hline & & Average of measurements & 10.8 & $\mathrm{~J}$ & \\
\hline & & Measured value & 11 & $\mathrm{~K}$ & \\
\hline & & Measured range & $7.4-19$ & $\mathrm{~N}$ & \\
\hline \multirow{3}{*}{\multicolumn{2}{|c|}{ Eau Claire confining unit }} & Simulated value & 2.0 & $\mathrm{D}$ & \multirow{3}{*}{$2^{\mathrm{a}}$} \\
\hline & & Simulated value & 2.5 & $\mathrm{E}$ & \\
\hline & & Measured value & 0.1 & $\mathrm{H}$ & \\
\hline \multirow{6}{*}{\multicolumn{2}{|c|}{ Mount Simon aquifer }} & Simulated value & 12 & $\mathrm{D}$ & \multirow{6}{*}{7} \\
\hline & & Simulated value & 12 & $\mathrm{E}$ & \\
\hline & & Measured range & $2-23$ & G & \\
\hline & & Average of measurements & 39.5 & $\mathrm{~J}$ & \\
\hline & & Measured value & 17 & $\mathrm{~K}$ & \\
\hline & & Measured range & $6.3-21$ & $\mathrm{~N}$ & \\
\hline & lits & Simulated range & $0.0056-0.28$ & $\mathrm{C}$ & 0.09 \\
\hline
\end{tabular}


Table 1A. Previously reported horizontal hydraulic conductivity $\left(\mathrm{K}_{\mathrm{h}}\right)$ and vertical hydraulic conductivity $\left(\mathrm{K}_{\mathrm{v}}\right)$ values, and calibrated values from the regional model.-Continued

$[\mathrm{ft} / \mathrm{d}$, foot per day; $<$, less than. Reference and source codes listed in table $1 B]$

\begin{tabular}{|c|c|c|c|c|c|}
\hline & & \multicolumn{2}{|c|}{ Hydraulic conductivity } & \multirow[b]{2}{*}{$\begin{array}{l}\text { Reference or } \\
\text { source code }\end{array}$} & \multirow{2}{*}{$\begin{array}{c}\text { Calibrated } \\
\text { value } \\
\text { (ft/d) }\end{array}$} \\
\hline \multicolumn{2}{|c|}{ Hydrogeologic unit } & Type & $\begin{array}{c}\text { Reference value } \\
\text { (ft/d) }\end{array}$ & & \\
\hline \multicolumn{6}{|c|}{ Vertical hydraulic conductivity } \\
\hline \multirow{3}{*}{\multicolumn{2}{|c|}{ Sand and gravel aquifer }} & Simulated value & 0.15 & $\mathrm{~A}$ & \\
\hline & & Simulated values & $0.4-4.2$ & $\mathrm{D}$ & $0.9^{\mathrm{b}}$ \\
\hline & & Simulated values & $4-12$ & $\mathrm{E}$ & \\
\hline \multirow{7}{*}{$\begin{array}{c}\text { Upper } \\
\text { bedrock } \\
\text { aquifer }\end{array}$} & Ancell-Prairie du & Simulated values & $0.003-6.2$ & A & \multirow{7}{*}{$0.005^{\mathrm{a}}$} \\
\hline & Chien-Jordan aquifer & Simulated value & 1 & $\mathrm{E}$ & \\
\hline & \multirow{5}{*}{$\begin{array}{l}\text { St. Lawrence-- } \\
\text { Tunnel City } \\
\text { confining unit }\end{array}$} & Simulated values & $0.3-3.6$ & A & \\
\hline & & Simulated values & $0.0003-0.003$ & $\mathrm{E}$ & \\
\hline & & Measured values & $0.0005-0.00008$ & $\mathrm{~F}$ & \\
\hline & & Measured range & $0.001-0.2$ & $\mathrm{H}$ & \\
\hline & & Measured range & $<0.0006-0.77$ & I & \\
\hline \multirow{4}{*}{\multicolumn{2}{|c|}{ Wonewoc aquifer }} & Simulated value & 3.3 & A & \multirow{4}{*}{$0.11^{\mathrm{b}}$} \\
\hline & & Simulated value & 1.2 & $\mathrm{E}$ & \\
\hline & & Measured range & $0.1-0.4$ & $\mathrm{H}$ & \\
\hline & & Measured range & $0.17-0.82$ & I & \\
\hline \multirow{4}{*}{\multicolumn{2}{|c|}{ Eau Claire confining unit }} & Simulated values & $0.6-0.006$ & $\mathrm{D}$ & \multirow{4}{*}{0.00009} \\
\hline & & Simulated value & 0.0003 & $\mathrm{E}$ & \\
\hline & & Measured value & 0.001 & $\mathrm{H}$ & \\
\hline & & Measured value & 0.0000002 & M & \\
\hline \multirow{2}{*}{\multicolumn{2}{|c|}{ Mount Simon aquifer }} & Simulated value & 1.2 & $\mathrm{D}$ & \multirow{2}{*}{$0.07^{\mathrm{b}}$} \\
\hline & & Simulated value & 1.2 & $\mathrm{E}$ & \\
\hline & Faults & Simulated range & $0.0056-0.28$ & $\mathrm{C}$ & 0.09 \\
\hline
\end{tabular}

${ }^{a}$ Indicates the value was specified, not calibrated.

${ }^{\mathrm{b}}$ Indicates the ratio $\mathrm{K}_{\mathrm{h}}: \mathrm{K}_{\mathrm{v}}$ was specified as 100:1.

Table 1B. Reference or source of horizontal and vertical hydraulic conductivity values reported in table $1 A$.

[MN, Minnesota; WI, Wisconsin]

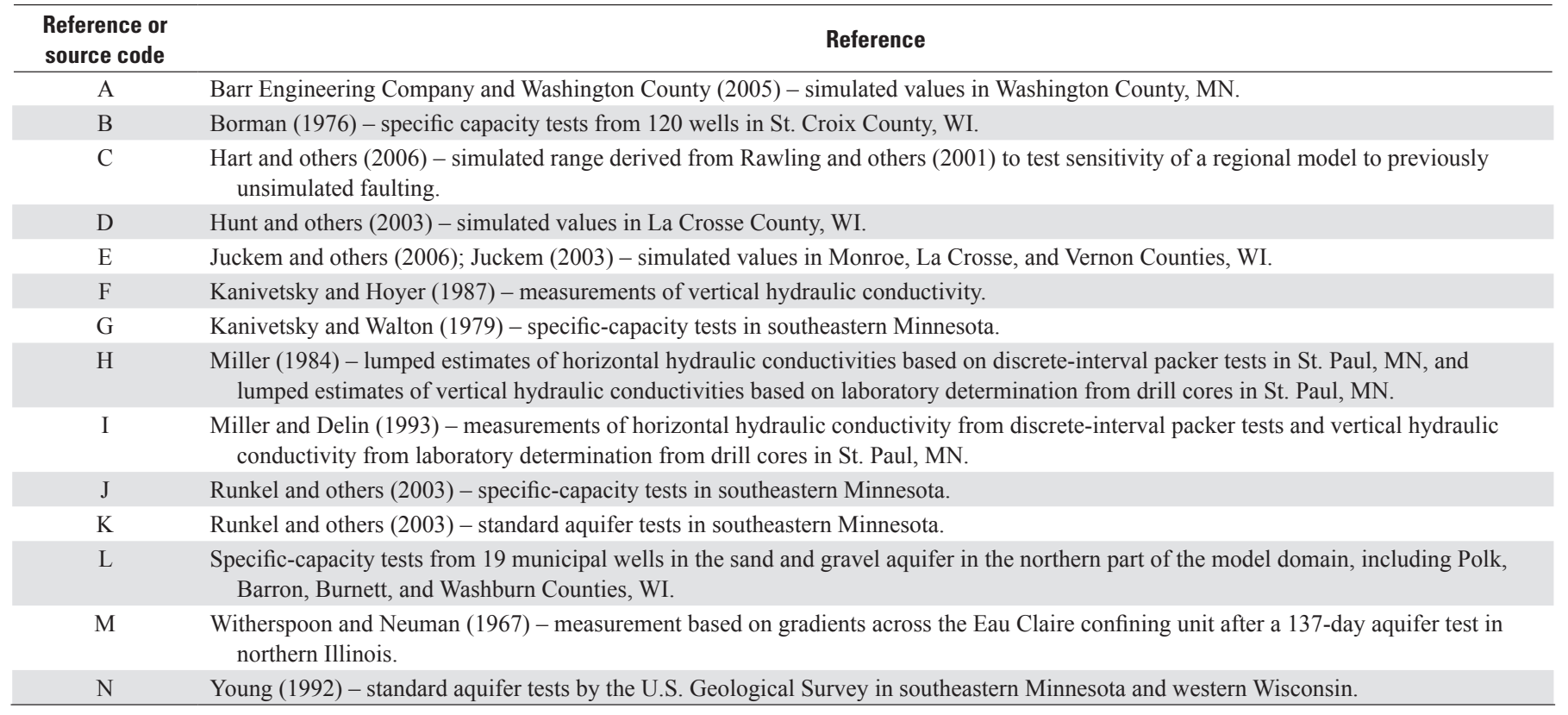


rate was applied uniformly across the regional model domain. The average groundwater-recharge rate was expected to fall within the range of values reported for previously calibrated groundwater-flow models and recharge-estimation studies in the area (table 2). The recharge rate was treated as a calibration parameter, with the value determined by use of the parameter estimation code PEST to match observed water levels and streamflows.

\section{Streambed Leakance}

Estimates of streambed leakance were needed to simulate the interaction between surface water and groundwater.
Streambed leakance is equal to the vertical hydraulic conductivity of a streambed or lakebed divided by its thickness, and in this study was estimated as ranging from 0.035 foot per day per foot $([\mathrm{ft} / \mathrm{d}] / \mathrm{ft})$ for lakes, the Mississippi River, and the St. Croix River downstream from Stillwater, MN, to $2(\mathrm{ft} / \mathrm{d}) / \mathrm{ft}$ for all other rivers and streams. This range is between values of 0.02 to $0.1(\mathrm{ft} / \mathrm{d}) / \mathrm{ft}$ simulated for lakes near Hayward, WI, by Juckem and Hunt (2007) and values of 1.6 to $37(\mathrm{ft} / \mathrm{d}) / \mathrm{ft}$ measured in streams in Dane County, WI, by Krohelski and others (2000). Because of the relative insensitivity of the regional flow system to riverbed leakance (see "Sensitivity Analysis" section), this parameter was not adjusted during calibration.

Table 2. Recharge rates from groundwater-flow models or other methods near the regional model area. The calibrated recharge rate used in the regional model of Pierce, Polk, and St. Croix Counties, Wisconsin, was 8.2 inches per year.

[in/yr, inch per year; MN, Minnesota; WI, Wisconsin; >, greater than; \%, percent; <, less than]

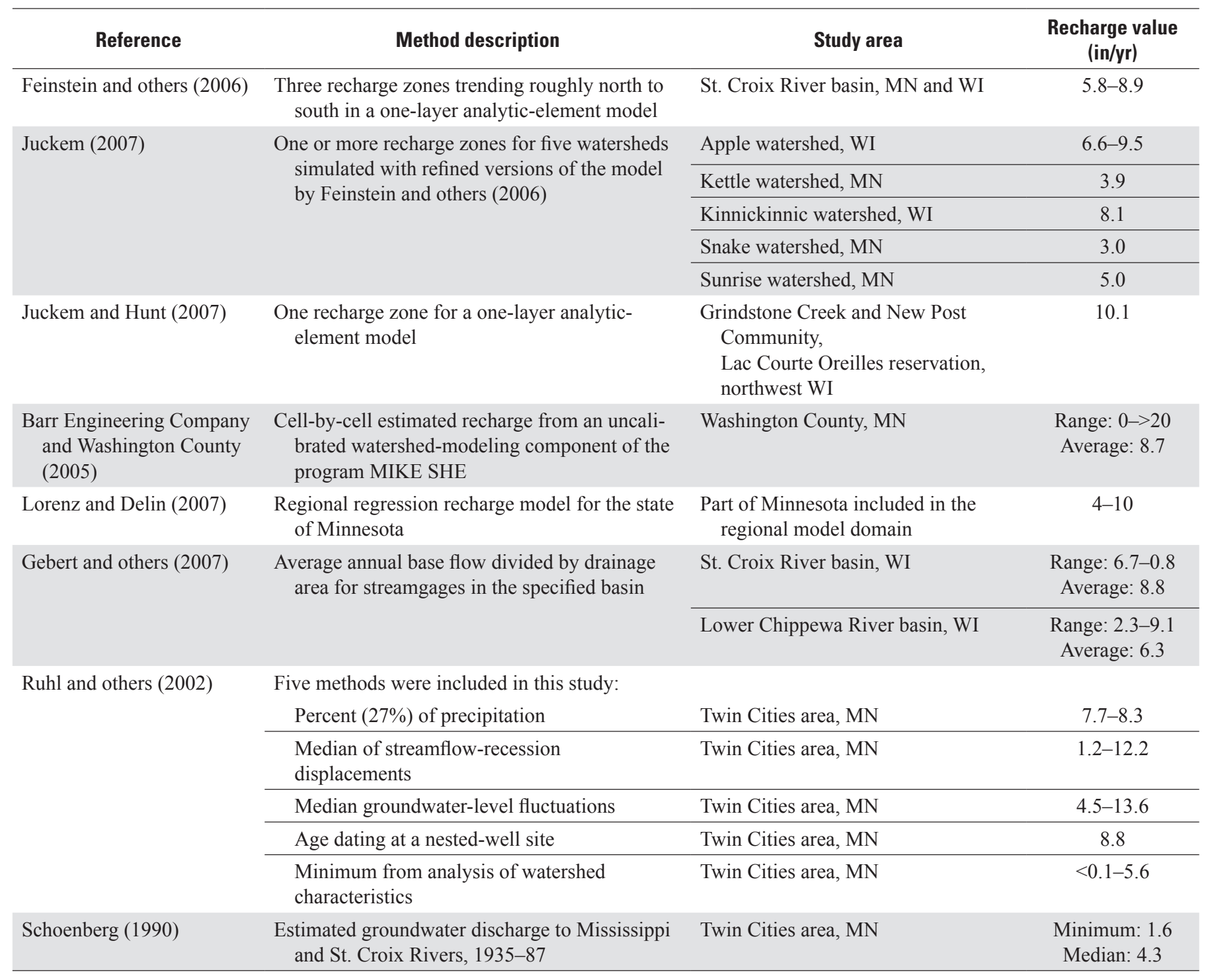




\section{Groundwater Withdrawals}

Pumping rates represented in the model for individual municipal wells in the three counties were computed as the average annual rate from 1994 to 2004 (Appendix 1). Nonmunicipal use (irrigation, industrial, and commercial) in the three counties was estimated as the average from 1978 to 1989 , the only period for which data were available (Appendix 2). Pumping from individual private wells in the counties is not included in the model because the discharge from these wells is widely distributed, relatively small (especially where balanced by return flow from septic systems), and negligibly significant on the overall regional water balance.

The estimated total high-capacity-well withdrawal for Pierce, Polk, and St. Croix Counties is 4,533 million gallons per year (Mgal/yr). Municipal water supplies in the three counties withdrew an average of about 2,975 Mgal/yr of groundwater from 1994 to 2004, or roughly 66 percent of the total groundwater withdrawn from all high-capacity wells. The largest municipal withdrawals in the individual counties were by the communities of River Falls in Pierce County (417 Mgal/yr); Clear Lake in Polk County (300 Mgal/yr), of which about 90 percent is used by local industries; and Hudson in St. Croix County (580 Mgal/yr). Generally, municipal withdrawals increased in Pierce, Polk, and St. Croix Counties at approximately 1, 1, and 5 percent per year, respectively, from 1994 to 2004. Groundwater withdrawal rates for irrigation, industrial, and commercial uses in the three counties were estimated at roughly $1,558 \mathrm{Mgal} / \mathrm{yr}$ based on data from 1978 to 1989.

The upper bedrock aquifer is the primary source of groundwater in the three counties and is used for most municipal and private drinking-water supplies, as well as for irrigation and industrial uses. The lower bedrock aquifers (Wonewoc and Mount Simon aquifers) are used by a few municipal systems, most notably the city of Hudson. The sand and gravel aquifer is used where it can supply sufficient quantities of water or where the upper bedrock aquifer is absent or thin in Polk and St. Croix Counties and along the St. Croix and Mississippi River Valleys in the three counties. Large-diameter wells can yield more than 1,000 gallons per minute ( $\mathrm{gal} / \mathrm{min}$ ) from the bedrock and sand and gravel aquifers where saturated thickness is sufficient (Borman, 1976).

\section{Three-Dimensional Simulation of the Regional Groundwater-Flow System}

The three-dimensional regional model and the demonstration inset models are mathematical representations of groundwater flow and use the USGS MODFLOW-2000 code (Harbaugh and others, 2000). The steps involved in developing the regional model were the following:
1. Input boundary conditions identified by the screening model and select appropriate aquifers and confining units as identified in the conceptual model.

2. Construct a finite-difference grid.

3. Assemble hydrologic data (for example, aquifer and confining-unit geometry and hydraulic conductivities, recharge rate, and leakance of streambeds).

4. Input pumping rates and locations of simulated wells.

5. Calibrate the model by use of the parameter estimation code PEST. The model is calibrated by adjusting selected parameters over realistic ranges until there is a reasonable match between measured and simulated groundwater levels and measured and simulated surface-water flows.

6. Ensure that the model is in mass balance; that is, the volume of water entering the model approximates the volume of water being withdrawn or leaving the model.

The steps involved in developing the inset demonstration models were identical to those described above, except for step 5; that is, many of the parameter values used in the demonstration models were taken directly from the regional model, whereas some parameter values were adjusted to improve the match to local water levels and streamflows where these data were available. Despite these improvements, the demonstration inset models are not considered calibrated, and their simulated results are intended for illustrative purposes only.

\section{Model Construction and Assumptions}

As currently implemented, the regional model simulates a steady-state groundwater system; that is, groundwater levels are not changing with time, and there is no change in groundwater storage. The steady-state assumption is appropriate because of the relatively constant rate of pumping over time and the close hydraulic connection between aquifers and surface water, which dampens the effect of transient stresses applied to the groundwater-flow system.

The sand and gravel aquifer was simulated wherever one of the four bedrock units was removed by erosion, and it is included in the three uppermost model layers (layers 1 to 3; fig. 7). This aquifer was divided into two zones representing alluvial valley sediments in the Chippewa, Mississippi, and St. Croix River Valleys and unlithified glacial deposits in northwestern Polk County. The bedrock units were combined into four model layers. Layer 1 consists of the unconfined upper bedrock aquifer (where present) above the shaly base of the Tunnel City Group (fig. 7). The altitude of the water table, which is computed during MODFLOW simulations, represents the top of an unconfined aquifer; in contrast, a low-permeability layer represents the top of a confined aquifer. Layer 2 in the model represents the confined Wonewoc aquifer, except where 


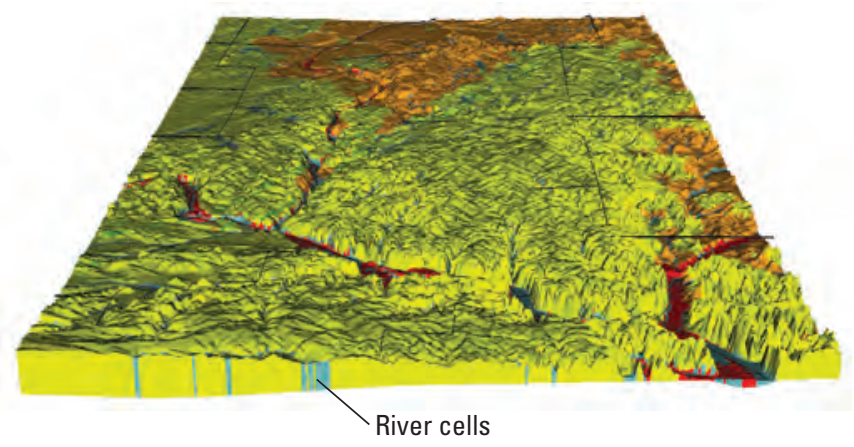

\section{Layer 1}

Sand and gravel aquifer (orange and red)

$\mathrm{K}_{\mathrm{h}}=90 \mathrm{ft} / \mathrm{d}$

$\mathrm{K}_{\mathrm{v}}=0.9 \mathrm{ft} / \mathrm{d}$

Upper bedrock aquifer (yellow)

$\mathrm{K}_{\mathrm{h}}=23 \mathrm{ft} / \mathrm{d}$

$\mathrm{K}_{\mathrm{v}}=0.005 \mathrm{ft} / \mathrm{d}$

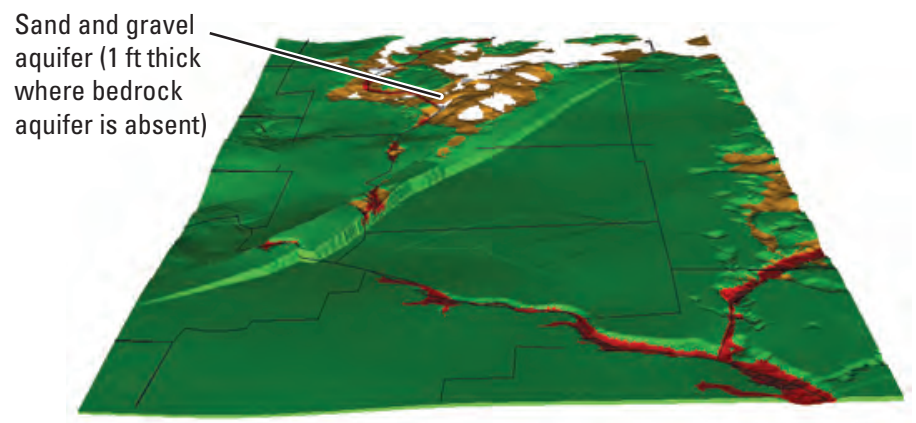

\section{Layer 2}

Sand and gravel aquifer (orange and red)

$\mathrm{K}_{\mathrm{h}}=90 \mathrm{ft} / \mathrm{d}$

$\mathrm{K}_{\mathrm{v}}=0.9 \mathrm{ft} / \mathrm{d}$

Wonewoc bedrock aquifer (green)

$\mathrm{K}_{\mathrm{h}}=11 \mathrm{ft} / \mathrm{d}$

$\mathrm{K}_{\mathrm{v}}=0.11 \mathrm{ft} / \mathrm{d}$

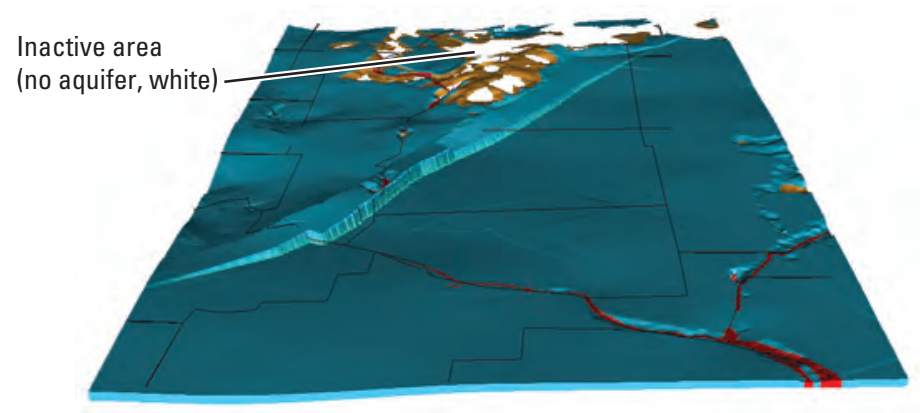

\section{Layer 3}

Sand and gravel aquifer (orange and red)

$\mathrm{K}_{\mathrm{h}}=90 \mathrm{ft} / \mathrm{d}$

$\mathrm{K}_{\mathrm{v}}=0.9 \mathrm{ft} / \mathrm{d}$

Eau Claire confining unit (light blue)

$\mathrm{K}_{\mathrm{h}}=2 \mathrm{ft} / \mathrm{d}$

$K_{v}=0.00009 \mathrm{ft} / \mathrm{d}$

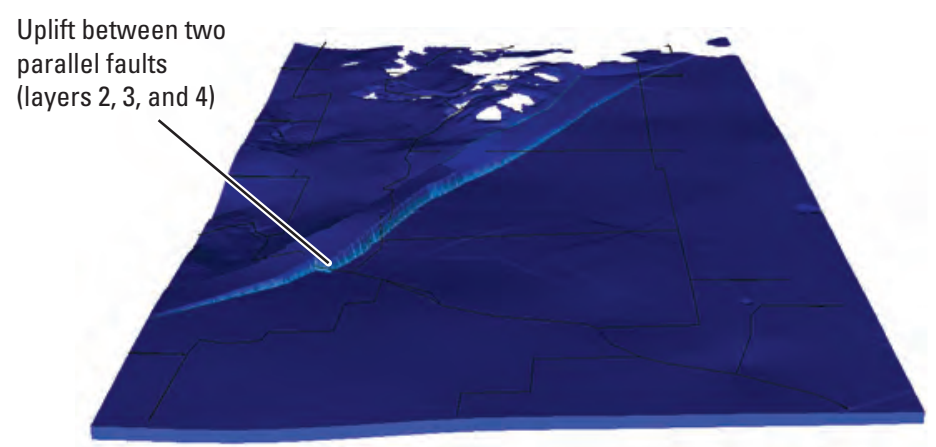

\section{Layer 4}

Mount Simon bedrock aquifer (blue)

$K_{h}=7 \mathrm{ft} / \mathrm{d}$

$K_{v}=0.7 \mathrm{ft} / \mathrm{d}$

Figure 7. The regional MODFLOW model layers and hydraulic-conductivity zones and values. (K $\mathrm{K}_{\mathrm{h}^{\prime}}$ horizontal hydraulic conductivity; $\mathrm{K}_{\mathrm{v}^{\prime}}$ vertical hydraulic conductivity; $\mathrm{ft} / \mathrm{d}$, foot per day)

it is eroded and, therefore, represented by the sand and gravel aquifer. Layer 3 represents the shaly Eau Claire confining unit, except where it is eroded. In parts of layers 2 and 3 where a bedrock unit was eroded away and represented by the sand and gravel aquifer, the layer was assigned a thickness of $1 \mathrm{ft}$, with the bulk of the sand and gravel aquifer thickness simulated in layer 1. Layer 4 represents the confined Mount Simon aquifer. This layer is underlain by relatively impermeable Precambrian crystalline bedrock that forms the model base. The four model layers are represented mathematically by horizontal and 
vertical hydraulic conductivities in the Layer-Property Flow Package (Harbaugh and others, 2000).

Two regional faults, where bedrock layers are vertically offset (figs. 3, 5, and 7), were simulated by adjusting the layer geometry (refer to "Model Grids" section) and adjusting the bedrock hydraulic conductivity in cells immediately adjacent to the faults. An area-averaged horizontal and vertical hydraulic conductivity was computed for these cells following the method of Hart and others (2006) by incorporating estimated properties of the bedrock in each layer and a single value for the fault zone; that is, horizontal hydraulic conductivity for these cells was computed as the harmonic mean of the bedrock conductivity for the layer and the fault-zone conductivity (table 1), assuming that the fault zone is $10 \mathrm{ft}$ wide. Similarly, vertical hydraulic conductivity for these cells was computed as the arithmetic mean of the bedrock vertical conductivity for the layer and the fault-zone conductivity. The fault zone was assumed to have the same vertical and horizontal conductivity. Based on the conceptual model of groundwater flow through fault zones proposed by Caine and others (1996), the harmonic mean was used to compute the effective horizontal hydraulic conductivity, and the arithmetic mean was used to compute the effective vertical hydraulic conductivity, because vertical faults are expected to decrease the effective horizontal conductivity and increase the effective vertical conductivity of an area relative to the adjacent bedrock. The influence of faulting on the regional flow system appears to be relatively minor (refer to "Sensitivity Analysis" section) but may be important locally. Finally, vertically uplifted Precambrian crystalline bedrock between the Hastings and Cottage Grove Faults is adjacent to the entire thickness of the Mount Simon aquifer along much of the faults. This effectively impermeable horizontal boundary was simulated in layer 4 (the Mount Simon aquifer) by incorporating the Horizontal Flow Barrier Package (HFB; Hsieh and Freckleton, 1993) for MODFLOW and assigning a very low horizontal hydraulic conductivity $\left(10^{-5} \mathrm{ft} / \mathrm{d}\right)$ to the barrier.

The MODFLOW model has perimeter boundary conditions extracted from the analytic-element screening model, which are assigned as specified-flux cells (by means of the MODFLOW Well Package). Flux values were determined from a single-layer MODFLOW extraction of the corresponding area of the GFLOW model. This area extended beyond the county boundaries by about 15 miles (mi), or a distance equal to three times the estimated characteristic leakage length (Haitjema, 2006, eq. 5) based on initial estimates of aquifer transmissivity in the Mount Simon aquifer and vertical resistance to flow across the Eau Claire confining unit. The characteristic leakage length (Haitjema, 2006, eq. 5) is equal to the square root of the product of aquifer transmissivity and the resistance of the overlying confining unit, with the confining-unit resistance computed as the thickness of the unit divided by the vertical hydraulic conductivity of the unit (the inverse of leakance). Haitjema (2006) demonstrates that 95 percent of vertical flow across a confining unit will occur within approximately three characteristic leakage lengths.
Thus, any boundary artifacts are expected to be mitigated over the $15 \mathrm{mi}$ between the MODFLOW model boundaries and the three counties. The perimeter flux values were distributed among multiple layers of the MODFLOW model by means of analytic element wells in the MODFLOW preprocessor Groundwater Vistas (Rumbaugh and Rumbaugh, 2007). This approach allows the constant flux to be automatically partitioned among model layers based on the transmissivity of individual cells.

Internal hydrologic boundaries include rivers and lakes within the model domain. These boundaries are headdependent flow boundaries; groundwater flow to or from these surface-water bodies depends on the difference in surfacewater and groundwater levels, the vertical conductivity and thickness of the riverbed (leakance), and the length and width of the river or lake in the model cells that encompass the surface-water body. The assumed riverbed leakance [2 (ft/d)/ft] indicates a close hydraulic connection; that is, the hydraulic conductivity of the riverbeds is such that river stages have a substantial effect on the local groundwater system. River-cell conductance (McDonald and Harbaugh, 1988) in the regional model varies on a cell-by-cell basis according to the length of the river contained within each cell, as determined by overlapping the MODFLOW grid on a 1:24,000scale hydrography map by use of a GIS. The Mississippi River, the St. Croix River downstream from Stillwater, MN, and all lakes simulated in the regional model also are assumed to be head-dependent flow boundaries that, despite their lower assumed leakance $[0.035(\mathrm{ft} / \mathrm{d}) / \mathrm{ft}]$, are also well connected to the groundwater-flow system because of their depth, large size, and low elevation.

In addition to boundary conditions, initial input to the models included the top and bottom elevations of each model layer, hydraulic conductivities, recharge rates, and pumping rates and locations of wells. Initial model input represents a cell average of the aquifer properties.

\section{Model Grids}

The regional three-dimensional, finite-difference ground-water-flow model covers a 66- by 114-mi area that is subdivided into 840,768 cells (348 columns, 604 rows, and 4 layers), of which 778,969 (93 percent) are active. The row and column dimensions of each cell are uniform throughout the model area, with each cell measuring 1,000 ft on a side and having an area of about 23 acres. This uniformly spaced grid was used to simulate all parts of the flow system.

Layer elevations were estimated from geologic-contact information identified from wells (Wisconsin Geological and Natural History Survey, 2003) and maps (Mossler, 1983). Layers were constructed by first interpolating the top elevation of the Precambrian crystalline bedrock, which forms the base of the model. This was performed separately for the area southeast of the Hastings Fault and northwest of the Cottage Grove Fault (fig. 8). The top elevation of the 

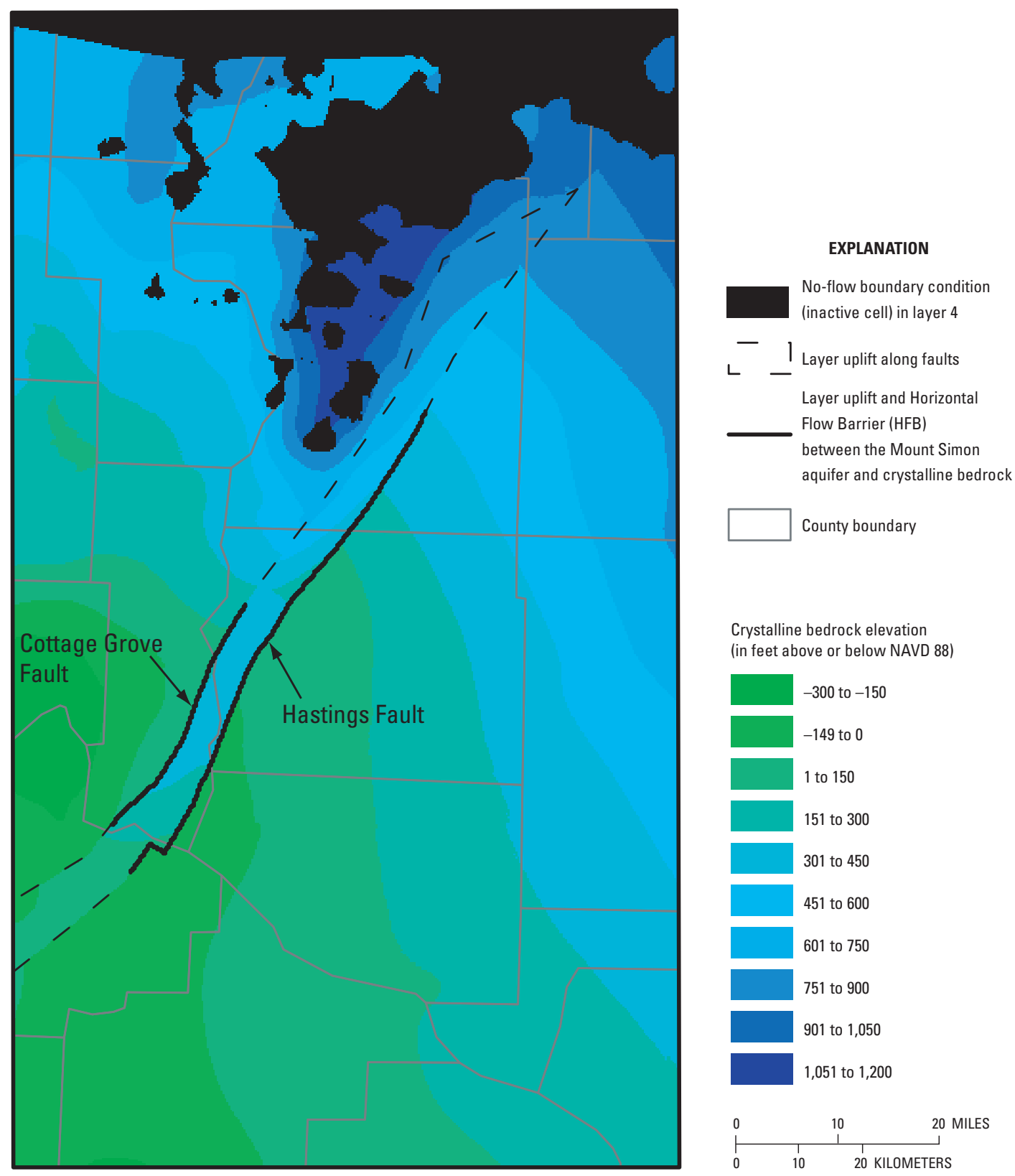

Crystalline bedrock elevation (in feet above or below NAVD 88)

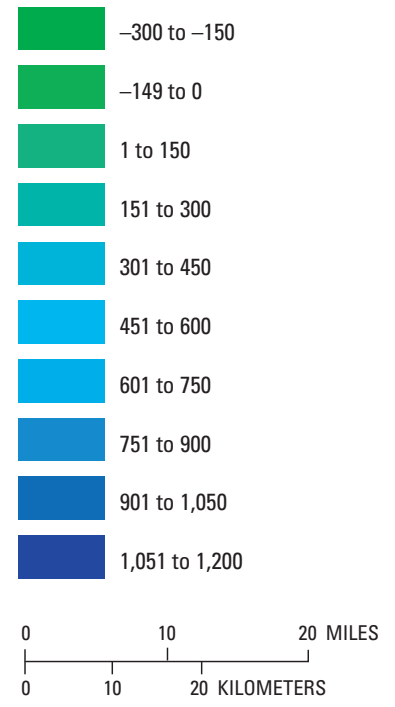

Figure 8. Interpolated crystalline bedrock elevation used to form the base of the regional model (layer 4), inactive cells in layer 4, and the location of faults (solid where simulated as an impermeable horizontal barrier between the Mount Simon aquifer and crystalline bedrock).

crystalline bedrock between the faults was estimated from reported uplift (Mudrey and others, 1987) and the interpolated elevations along the edge of the faults. The thicknesses of aquifers and confining units were interpolated across the entire study area. Thickness, rather than contact elevation, was used because thickness was expected to be less affected by faulting and could therefore be interpolated across the entire model domain without consideration of faulting, which occurred after deposition of the Cambrian and Ordovician sedimentary rocks. The base of layer 3 (contact between the Mount Simon aquifer and Eau Claire confining unit) was then computed by adding the layer thickness of the Mount Simon to the top elevation of the crystalline bedrock. Similarly, the base of layer 2 was computed by adding the thickness of the Eau Claire to the bottom elevation of layer 3 . The base of layer 1 was computed by adding the thickness of the Wonewoc aquifer to the bottom elevation of layer 2. The top of layer 1 was interpolated from a digital elevation model.

A top-of-bedrock surface was interpolated from wellconstruction data (Wisconsin Geological and Natural History Survey, 2003; Wisconsin Department of Natural Resources, 2003). This surface incorporated more data because the type of 
rock was unimportant, making this surface more detailed than the previously interpolated top and bottom elevations for the layers. Cells in layer 4 were deactivated (no-flow boundary) where the crystalline bedrock surface (bottom of layer 4) matched or exceeded the top-of-bedrock surface, indicating that the Mount Simon aquifer is absent. Cells in layer 3 were deactivated where the Mount Simon was absent and the bottom of layer 3 matched or exceeded the top-of-bedrock surface. Similarly, cells in layer 2 were deactivated where the Eau Claire was absent (inactive) and the bottom of layer 2 matched or exceeded the top-of-bedrock surface; cells in layer 1 were deactivated if the Wonewoc was absent and the bottom of layer 1 matched or exceeded the top-of-bedrock surface. For cells in which the bottom elevation matched or exceeded the top of bedrock, but the layer below was not inactive (that is, the underlying aquifer or confining unit was present), the bottom elevation was adjusted downward to produce a layer that was $1 \mathrm{ft}$ thick and represented by the sand and gravel aquifer.

The layer interpolation method included the assumption of gradual changes in the crystalline bedrock elevation (except at the Hastings and Cottage Grove Faults) and sedimentary bedrock thickness over a regional scale. Locally, this assumption may be violated where the crystalline bedrock elevation or aquifer thickness changes rapidly, such as in central and northern Polk County. In this area, some local crystalline bedrock ridges may not be represented in the model, and layer thicknesses may locally differ from lithologic contacts described from well cuttings. Extraction of inset models, particularly those near crystalline bedrock ridges in Polk County, may benefit from local reinterpolation of layer geometries.

\section{Model Calibration}

The model was calibrated by use of PEST (Doherty, 2004). The PEST parameter estimation routine automatically adjusted parameter values and compared simulated groundwater levels and stream gains to measured water levels and base flows after each model run. The parameter estimation continued until simulated water levels and base flow matched measured water levels and base flow as closely as possible given the model construction and relative importance (weight) assigned to each measurement.

Although a steady-state model was used (in which groundwater levels do not change with time), measured water levels used during calibration spanned many years, and their location is somewhat uncertain. Because of these uncertainties, along with simplifications inherent in constructing a regional model, perfect agreement between the simulated and measured values was not expected. An approximate evaluation of data quality is included in the calibration by way of the PEST weight assigned to each target (table 3). The weighted residuals between measured and simulated values were used by PEST to determine the best fit. Water-level targets were arranged into four categories: (1) median values from long-term groundwater-observation wells in Pierce, Polk, and St. Croix Counties, (2) median values from long-term groundwater-observation wells outside of Pierce, Polk, and St. Croix Counties, (3) median values from observation wells with irregular measurement intervals, and (4) water levels from well-construction reports used by the Wisconsin Geological and Natural History Survey to compile water-table maps for Pierce, Polk, and St. Croix Counties (Lippelt,

Table 3A. Mean error, mean absolute difference, and root mean squared difference between simulated and measured groundwater levels. Associated weights used for calibration with the parameter estimation program PEST (Doherty, 2004) also are shown.

[ft, foot; WGNHS, Wisconsin Geological and Natural History Survey; n/a, not applicable]

\begin{tabular}{|c|c|c|c|c|c|}
\hline Well type & $\begin{array}{l}\text { Number of } \\
\text { targets }\end{array}$ & $\begin{array}{c}\text { Mean } \\
\text { error } \\
(\mathrm{ft})\end{array}$ & $\begin{array}{l}\text { Mean absolute } \\
\text { difference } \\
\text { (ft) }\end{array}$ & $\begin{array}{l}\text { Root mean } \\
\text { squared } \\
\text { difference } \\
\text { (ft) }\end{array}$ & Weight \\
\hline $\begin{array}{l}\text { Median of time-series values at long-term observation } \\
\text { wells in Pierce, Polk, and St. Croix Counties }\end{array}$ & 5 & 6.8 & 12.8 & 15.9 & $1-10^{\mathrm{a}}$ \\
\hline $\begin{array}{l}\text { Median of time-series values at long-term observation } \\
\text { wells outside of Pierce, Polk, and St. Croix Counties }\end{array}$ & 33 & 6.9 & 12.7 & 15.7 & $0.5-10^{\mathrm{b}}$ \\
\hline $\begin{array}{l}\text { Median of time-series values at observation wells with } \\
\text { irregular measurements }\end{array}$ & 22 & -13.3 & 17.8 & 26.8 & $0.5-1^{\mathrm{c}}$ \\
\hline $\begin{array}{l}\text { Well-construction-report data used by WGNHS to map } \\
\text { water tables in Pierce, Polk, and St. Croix Counties }\end{array}$ & 2,831 & -8.0 & 25.7 & 36.4 & 0.01 \\
\hline All water-level targets & 2,891 & -7.9 & 25.5 & 36.2 & $\mathrm{n} / \mathrm{a}$ \\
\hline
\end{tabular}



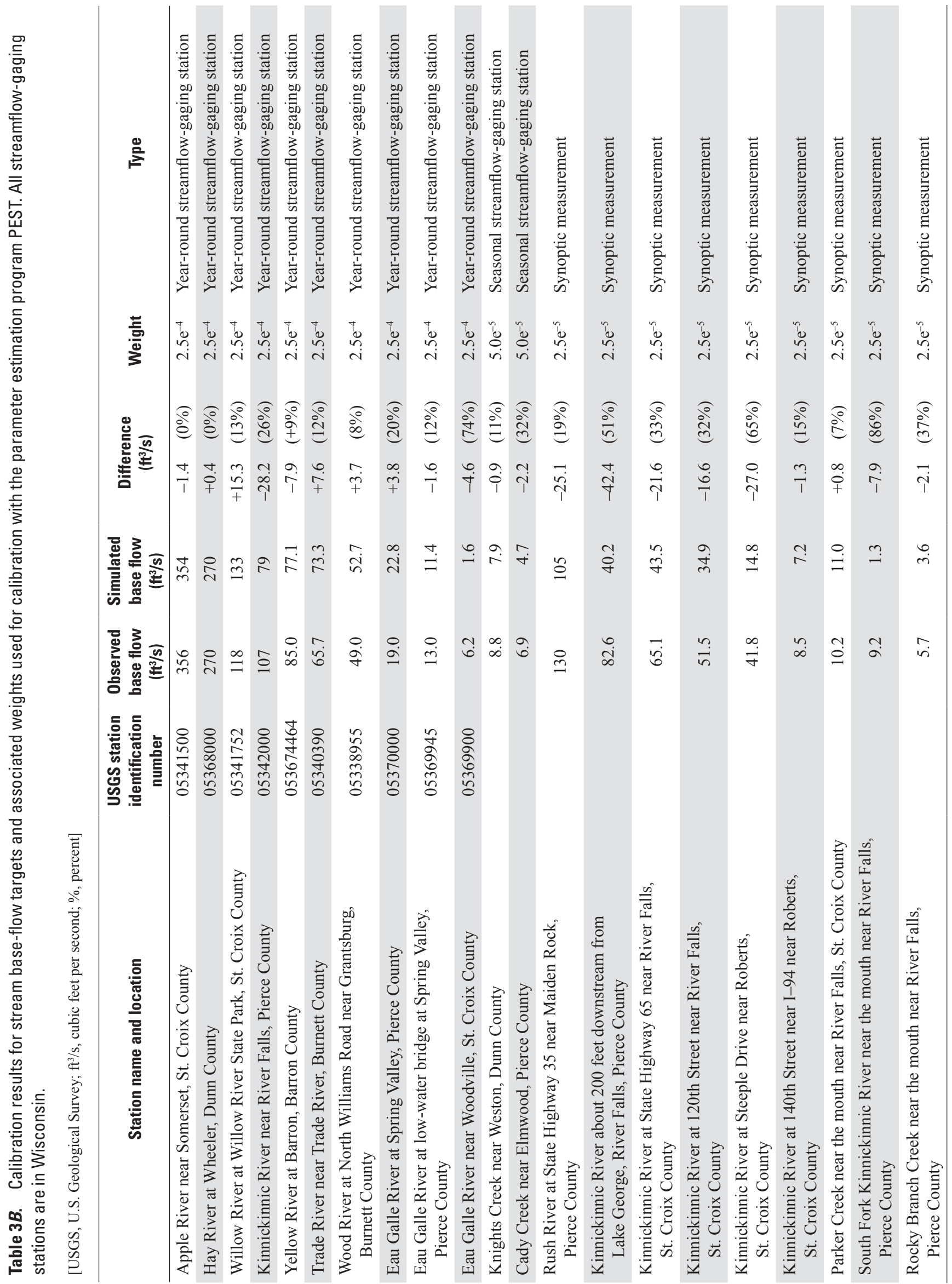
1990a, b; Muldoon, 2000). Higher weights were assigned to wells with long records and accurately measured referencepoint elevations; lower weights were assigned to wells with just one or a few measurements and less accurately estimated elevations. In addition, a long-term observation well in Lake City, MN, is on a peninsula in the Mississippi River, where the river stage is well known. The difference between the Mississippi River stage and the water level in the Lake City observation well (Minnesota unique well number 222329) was computed and used as a head-gradient target for calibration with PEST. Finally, base-flow measurements were assigned weights (table $3 B$ ) according to three categories: (1) yearround streamflow-gaging stations, (2) seasonal (non-freezeperiod) streamflow-gaging stations, and (3) one-time synoptic measurements. The highest weights were assigned to yearround gages; the lowest weights were assigned to synoptic measurements. These base-flow measurements were compared to simulated stream gains as part of the model calibration.

Values for hydraulic conductivity used in the final calibrated model are shown in table 1 and in figure 7 . Only a subset of all possible parameters was estimated by PEST. Parameters were excluded if they were insufficiently sensitive (for example, vertical hydraulic conductivity of aquifers) for automated calibration. In these cases, the parameter value was either set equal to a value within the range reported in table 1 or tied to another parameter at a specified ratio. For example, a 100:1 ratio was specified between the horizontal and vertical hydraulic conductivities of many aquifers due to insensitivity of vertical hydraulic conductivity for these units. Similarly, values of other parameters were limited such that their value could not exceed that of another parameter. For example, horizontal hydraulic conductivity of alluvial sediments in the Chippewa, St. Croix, and Mississippi River Valleys was allowed to vary but was assigned a lower bound equal to the horizontal hydraulic conductivity of the upland glacial sediments, which was concurrently calibrated. The calibrated horizontal hydraulic conductivity representing the glacial sediments is $90 \mathrm{ft} / \mathrm{d}$; alluvial-valley sediments were estimated with the same value and are therefore lumped with the glacial sediments and referred to collectively as the sand and gravel aquifer in this report. Horizontal hydraulic conductivities calibrated for the upper bedrock aquifer, the Wonewoc aquifer, and the Mount Simon aquifer are 23, 11, and $7 \mathrm{ft} / \mathrm{d}$, respectively. The Eau Claire confining unit was assigned (not calibrated, because of low sensitivity) a horizontal hydraulic conductivity of $2 \mathrm{ft} / \mathrm{d}$ (Hunt and others, 2003) for the entire model domain, which represents the ability of the confining unit to transmit water laterally through the thin sandstone lenses within the unit. The ratio of horizontal to vertical hydraulic conductivity $\left(\mathrm{K}_{\mathrm{h}}: \mathrm{K}_{\mathrm{v}}\right)$ was fixed at 100:1 for the sand and gravel aquifer, Wonewoc aquifer, and Mount Simon aquifer, which corresponds to vertical hydraulic conductivities of $0.9,0.11$, and $0.07 \mathrm{ft} / \mathrm{d}$, respectively. The vertical hydraulic conductivity for the upper bedrock aquifer was assigned a value of $5 \times 10^{-3} \mathrm{ft} / \mathrm{d}$, which equates to $\mathrm{K}_{\mathrm{h}}: \mathrm{K}_{\mathrm{v}}$ ratio of $4,600: 1$ and reflects the laterally extensive low-permeability confining unit commonly associated with the base of the Tunnel City Group (Young, 1992; Miller and Delin, 1993; Juckem, 2003; R.G. Tipping, Minnesota Geological Survey, written commun., 2005). This value was relatively insensitive during model calibration (see "Sensitivity Analysis" section). The Eau Claire confining unit also contains laterally extensive layers of shale, resulting in a calibrated vertical hydraulic conductivity of $9 \times 10^{-5} \mathrm{ft} / \mathrm{d}\left(\mathrm{K}_{\mathrm{h}}: \mathrm{K}_{\mathrm{v}}\right.$ ratio of about $\left.20,000: 1\right)$. The hydraulic conductivity of faults was estimated to be $0.09 \mathrm{ft} / \mathrm{d}$, which is within the range suggested by Hart and others (2006).

Field-measured groundwater levels were compared to model-calculated groundwater levels (fig. 9) at specific model cells. Water-level measurements from 2,831 drillers' construction reports in Pierce, Polk, and St. Croix Counties that spanned approximately 50 years from 1950 to 2000 were compared to model-calculated water levels. These water-level targets provide data on the water table in the sand and gravel and the upper bedrock aquifers. Water levels from 60 monitoring wells with either continuous or irregular measurements also were compared to model-calculated water levels. Median water levels measured in these monitoring wells are more representative of average conditions for the study period than are water levels from well-construction reports and were therefore given higher weight during model calibration. Of the 60 monitoring wells, 9 are open to the deeper Wonewoc aquifer, Eau Claire confining unit, or Mount Simon aquifer. Measured water levels in these nine wells represent the potentiometric surface of these lower units and were compared to model-calculated water levels in the associated layer. Of special importance was the calculated gradient between the Mississippi River stage and the water level in the observation well in Lake City, MN (unique well number 222329), which was closely simulated (within $0.2 \mathrm{ft}$ ).

The summary statistics for the groundwater-level calibration from the regional model (table $3 A$ ) are similar to what has been observed in other regional models in Wisconsin. The mean error of all the groundwater-level targets in the regional model (a measure of the model bias) is $-7.9 \mathrm{ft}$ (fig. 10; a negative value indicates that measured values were less than simulated values); the mean errors for the water table (layer 1) and all potentiometric heads (layers 2, 3, and 4) are -7.9 and $1.5 \mathrm{ft}$, respectively. The root mean square differences (RMSD) between measured and simulated water levels for the water table and potentiometric heads are 36.1 and $17.6 \mathrm{ft}$, respectively. The mean absolute difference (MAD) is $25.5 \mathrm{ft}$ for the water table and $15.1 \mathrm{ft}$ for potentiometric heads. These RMSD and MAD values represent less than 6 percent of the total range of observed water levels across the model area.

In addition to comparing measured and modeled water levels by means of summary statistics, spatial comparisons between the measured and simulated water table (layer 1) and potentiometric surfaces in layers 2 and 4 were made (figs. 11, 12, and 13). The agreement between simulated water levels and measured water levels in observation wells (figs. 11 $\mathrm{A}$, 12 , and 13) is generally close and shows little spatial bias. The match to well-construction-report water levels (fig. 11B) 


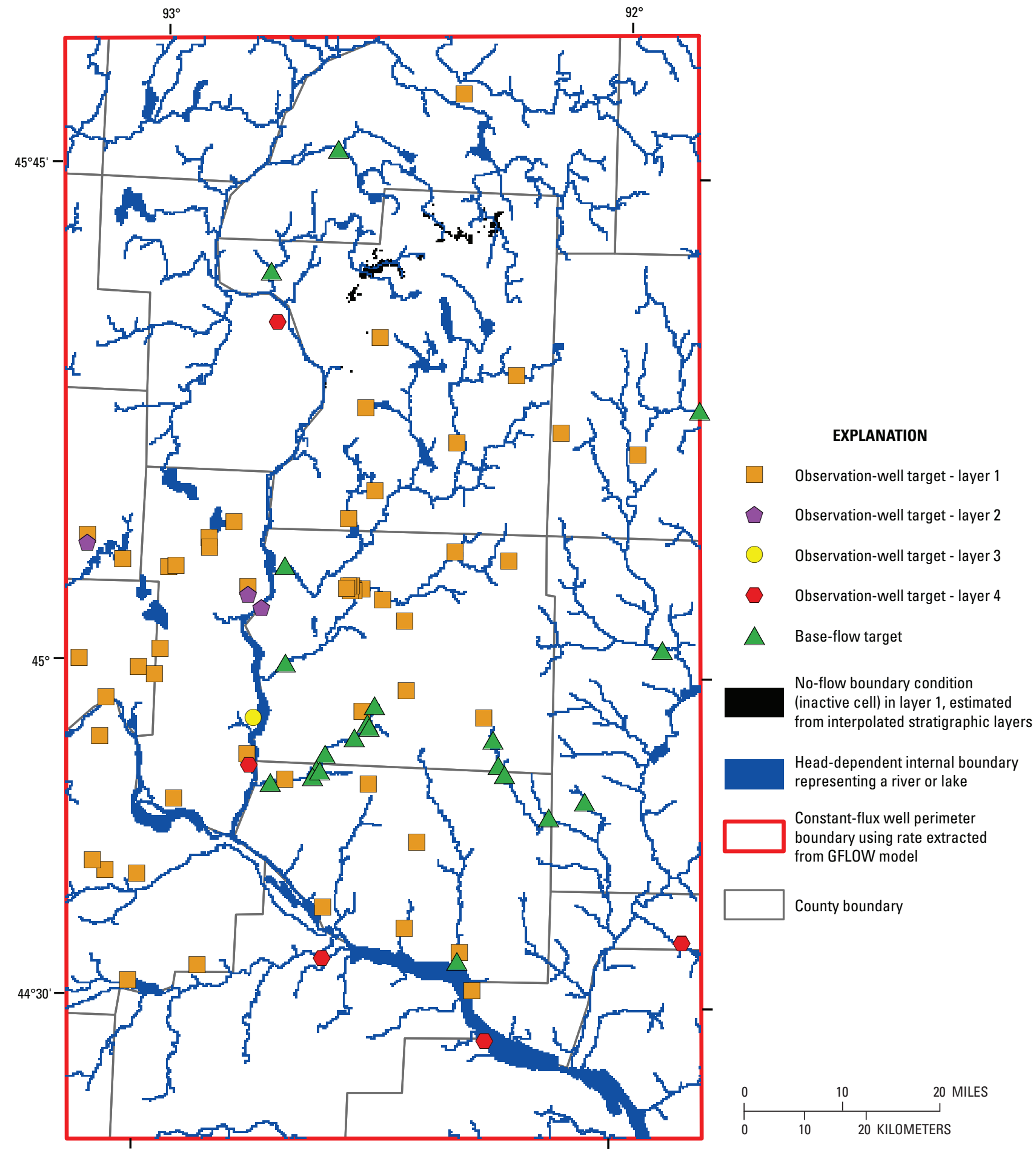

Figure 9. Perimeter and internal boundary conditions, water-level-observation wells, and base-flow targets in the regional model of Pierce, Polk, and St. Croix Counties, Wisconsin. 


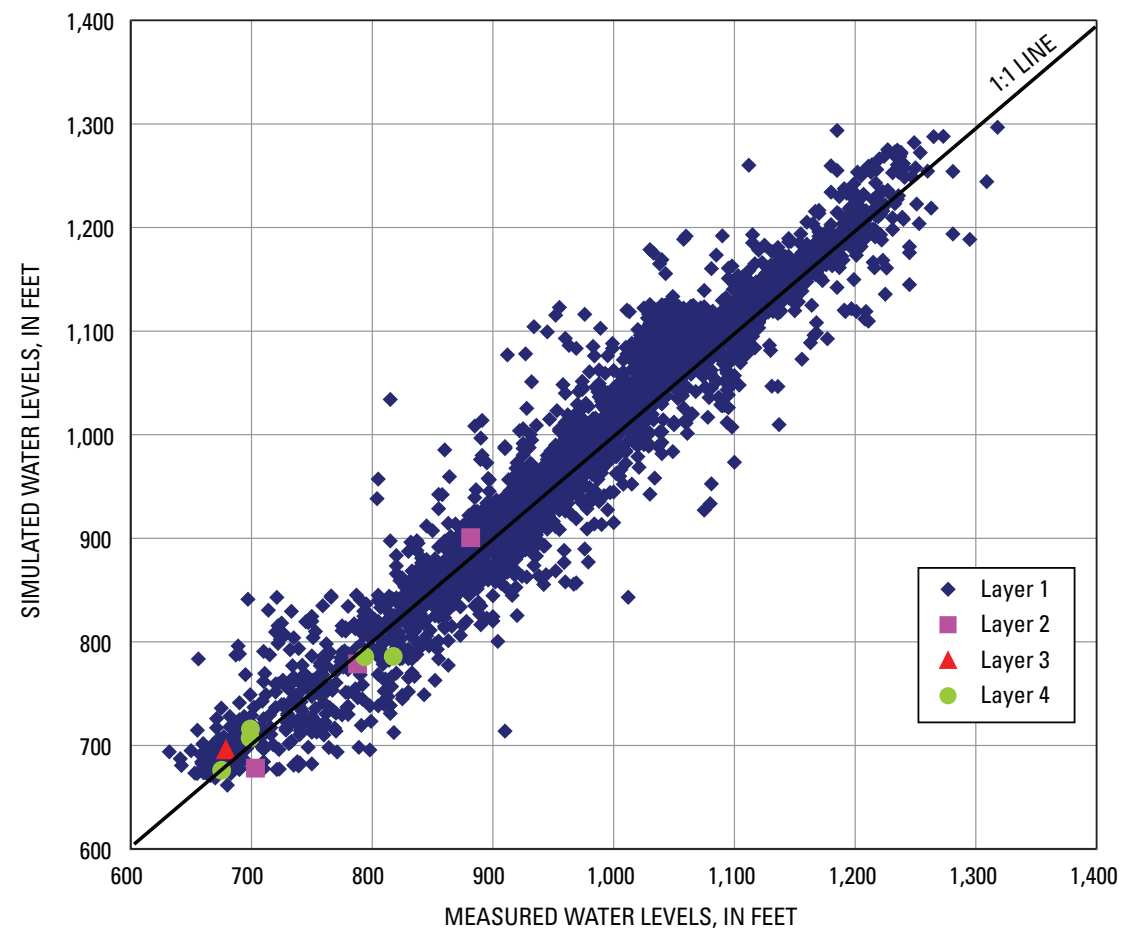

Figure 10. Measured water levels plotted against simulated water levels for the regional model.

shows some banding, with simulated water levels greater than observed water levels in northwestern Polk County and central St. Croix County. The area of high simulated water levels in northwestern Polk County coincides with an area in which groundwater levels are commonly 50 to $100 \mathrm{ft}$ below surfacewater levels (Muldoon, 2000) and the system is characterized by a local, upper perched water table and a lower regional water table. This level of local flow-system complexity was not simulated in the regional model, in which stacked local systems were simplified into one upper model layer. Likewise, the area of high simulated water levels in central St. Croix County may be a result of simulating vertically averaged aquifer properties for multiple hydrostratigraphic units with a single upper bedrock aquifer layer. The units lumped into layer 1 in this area have appreciably different hydraulic properties. In addition, these units were simulated with one parameter zone in the model. Aquifer simplification through large-scale parameter zonation provides parsimony in a regional model, but it can also limit calibration (Hunt and others, 2007). Shallow groundwater flow in central St. Croix County is dominated by the karstic Prairie du Chien aquifer, which was lumped in the regional model with underlying sandstone aquifers represented by the Trempealeau and Tunnel City Groups. Cobb (2007) describes the Prairie du Chien Group as having "extreme" horizontal to vertical anisotropy. Horizontal transmissivity is large and flow is rapid (several measurements of local groundwater-flow velocities exceeded $150 \mathrm{ft} / \mathrm{d}$ ), yet the water table is commonly near the top of the Prairie du Chien Group and vertical gradients are steep, indicating a low vertical hydraulic conductivity (Cobb, 2007). Because there is little physical data related to spatial changes in hydraulic properties of the Prairie du Chien Group at the regional scale, effects of flow through karst features could not easily be limited to discrete areas in the model. Rather, karst features are observed throughout the extent of the Prairie du Chien Group in Pierce and St. Croix Counties (Cobb, 2007, fig. 3.8). Including this level of geologic complexity was beyond the scope of regional model calibration; thus, the area of the banded residuals were investigated by use of the demonstration model for the area (described below) rather than the regional model described here.

Measured base flows were compared to simulated base flows at 21 locations (fig. 14). Streamflow was measured continuously for several years between 1994 and 2004 at 10 yearround streamflow-gaging stations and during the summers of 2002 and 2003 at two seasonal streamflow-gaging stations (table $3 B$ ). These streamflow data were used in conjunction with an automated hydrograph separation program, BFI (Wahl and Wahl, 1995), to estimate base flow for each streamflowgaging station. Streamflow was measured once at an additional nine synoptic measurement locations (table $3 B$ ). Simulated base flows generally matched measured base flows, with five of the year-round streamflow-gaging stations having simulated base flows greater than measured base flows; simulated base flow was less than measured base flow at the other five year-round streamflow-gaging stations. Simulated base flow was less than measured base flow at 10 of the 11 seasonal gages and synoptic measurement sites, and this discrepancy is 


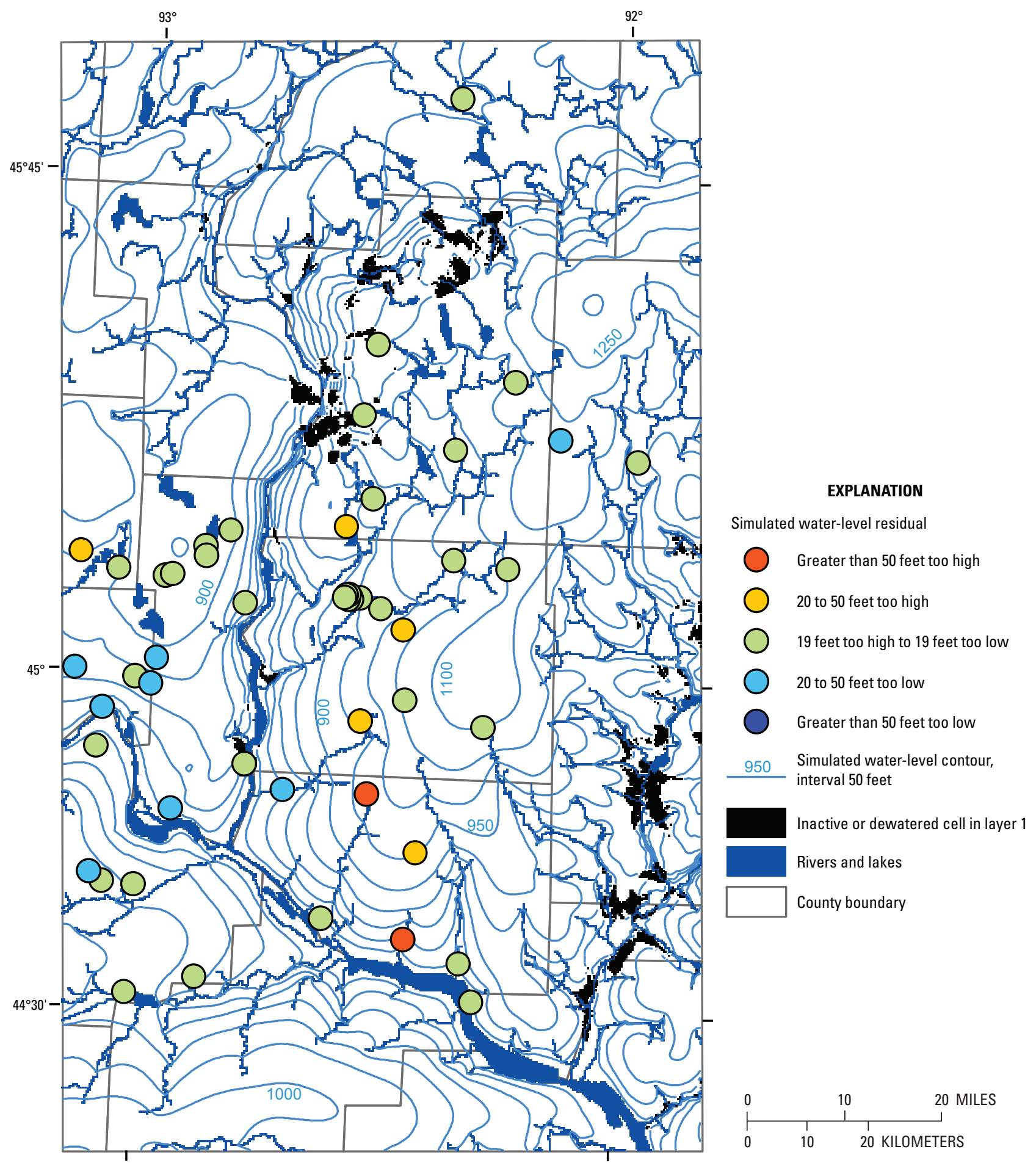

Figure 11A. Simulated water-table elevation and water-level residuals for observation wells in the regional groundwater-flow model, layer 1. 


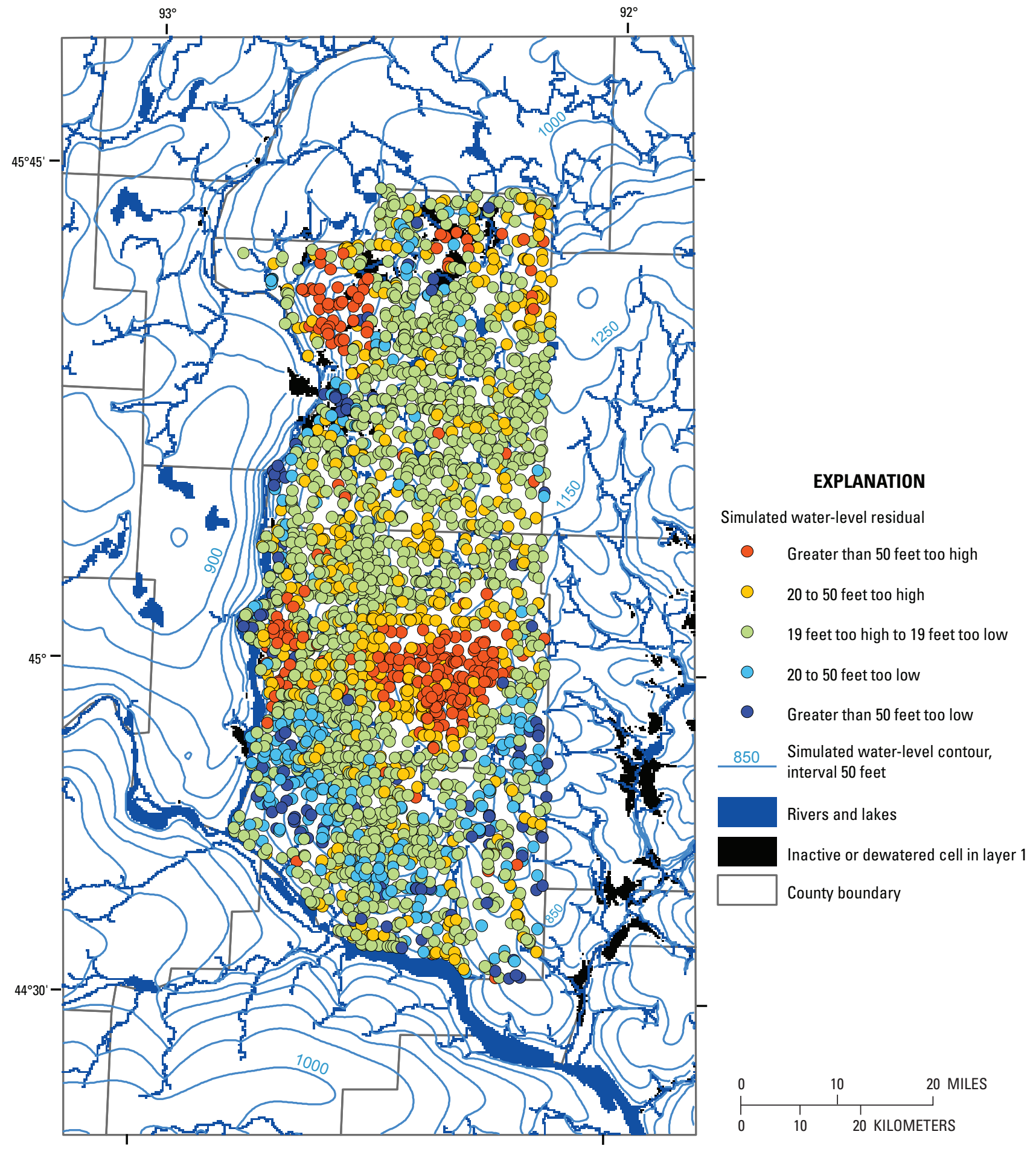

Figure 11B. Simulated water-table elevation and water-level residuals for well-construction-report wells in the regional groundwater-flow model, layer 1. 


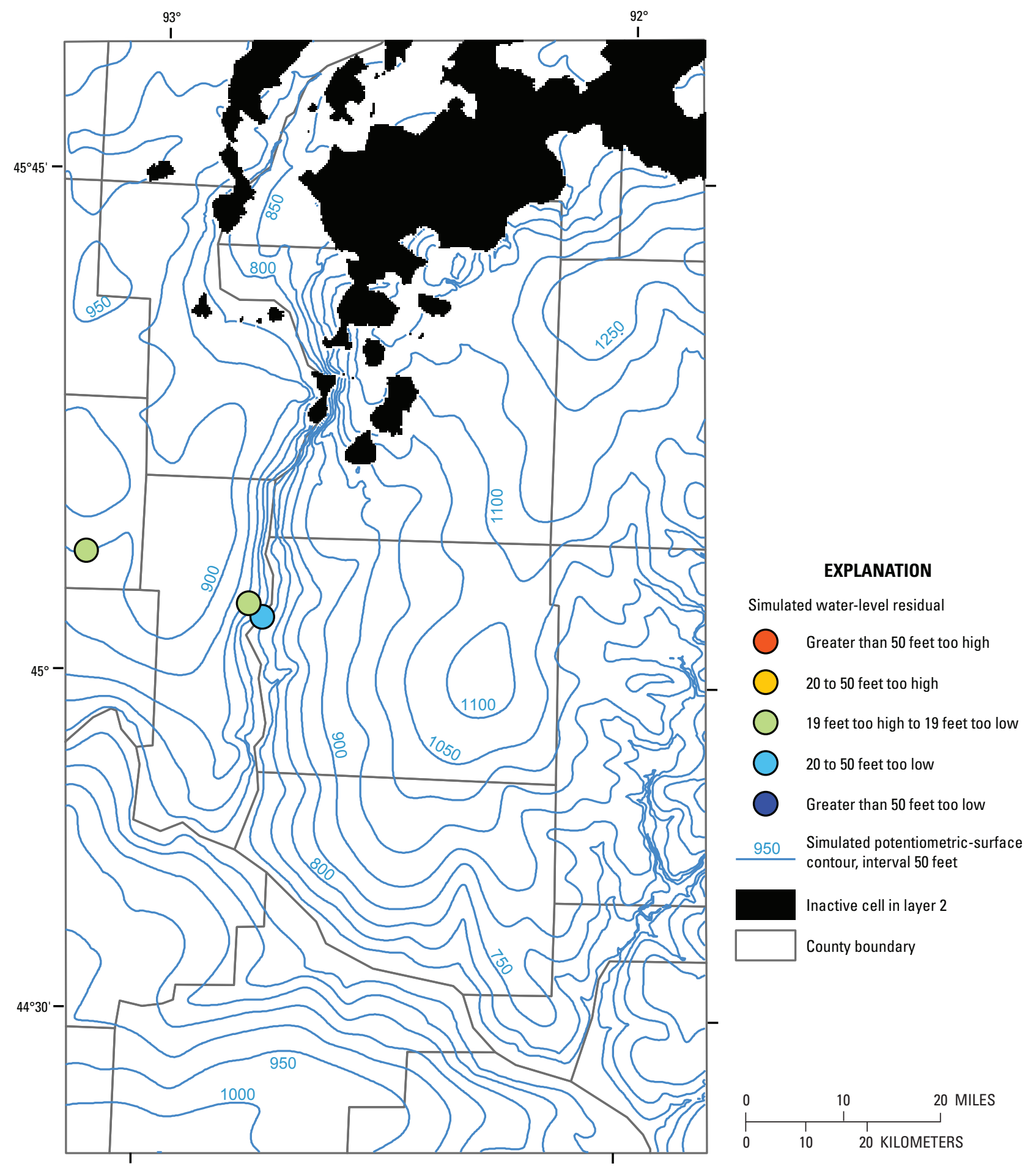

Figure 12. Simulated potentiometric-surface elevation and water-level residuals for observation wells in the regional groundwater-flow model, layer 2. 


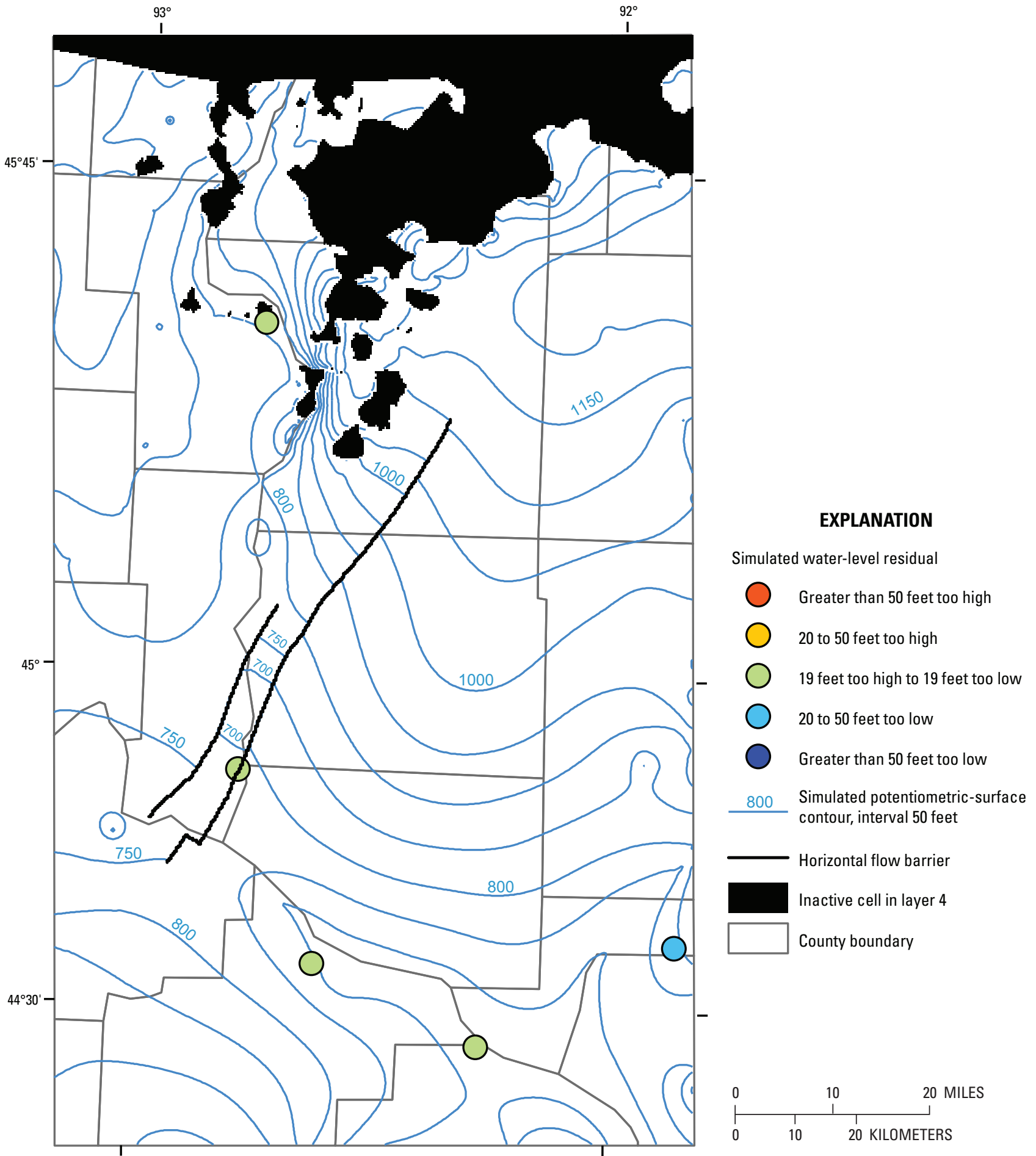

Figure 13. Simulated potentiometric-surface elevation and water-level residuals for observation wells in the regional groundwater-flow model, layer 4. 


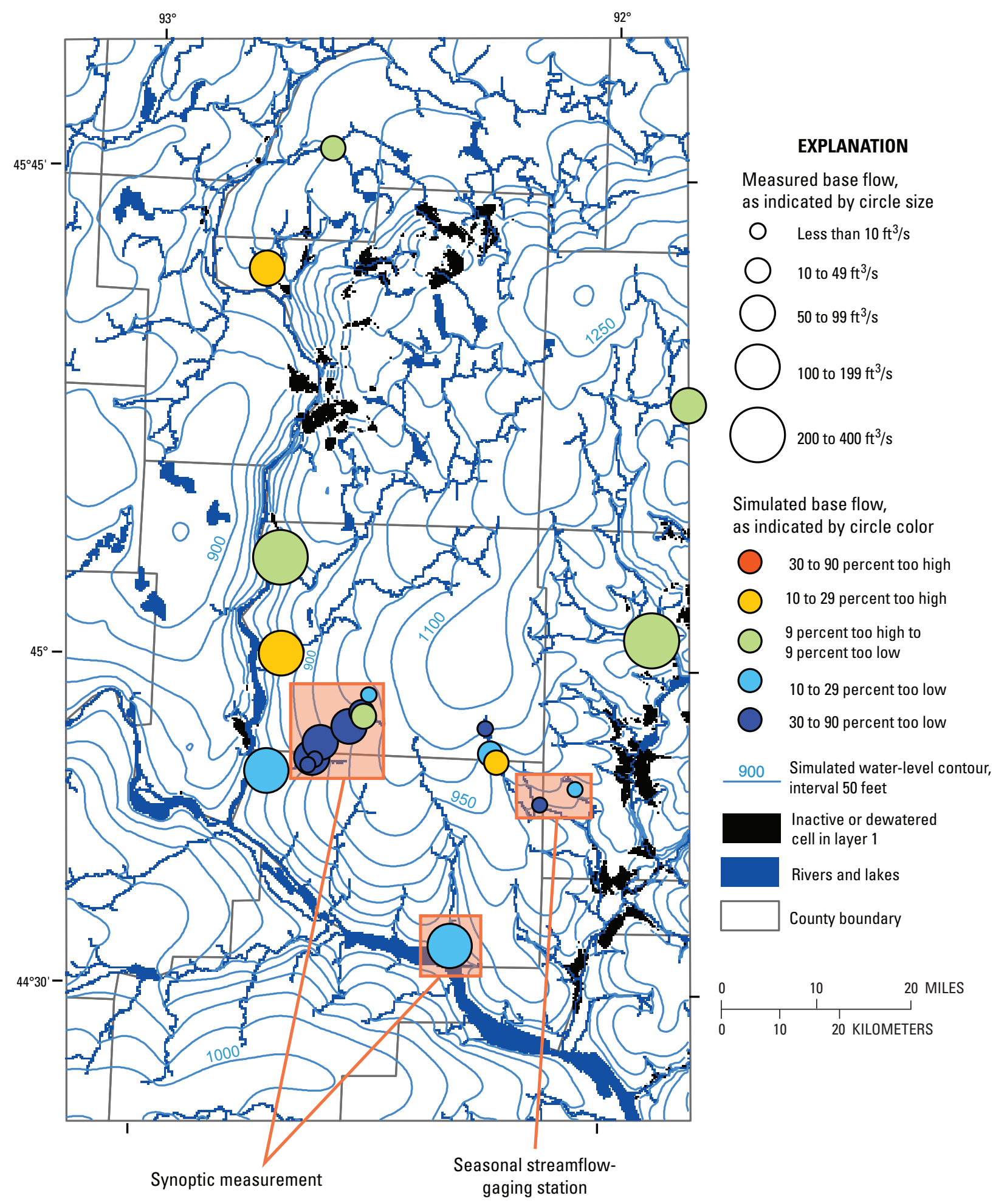

Figure 14. Simulated water-table elevation and residuals for stream base-flow measurements in the regional groundwaterflow model, layer 1 ( $\mathrm{ft}^{3} / \mathrm{s}$, cubic feet per second). 
likely related to difficulty in matching simulated groundwater divides in the headwater area of the Kinnickinnic and Rush Rivers with mapped divides (Lippelt, 1990b). The base-flow targets simulated within the MODFLOW model domain were sufficient to constrain the recharge rate in the MODFLOW model. Recharge was applied uniformly to the uppermost active layer and calibrated at a rate of 8.2 inches per year (in/yr), which is similar to rates estimated by others in southeastern Minnesota and western Wisconsin (table 2).

\section{Sensitivity Analysis}

Some uncertainty always exists about the accuracy of models because the model parameter values are never exactly known. However, the importance of each input parameter and its effect on simulation results can be evaluated through sensitivity tests in which the value of a parameter, such as hydraulic conductivity, is adjusted above or below the calibrated value and the magnitude of changes in simulated groundwater levels and base flows are quantified. In this study, PEST was used to calculate the sensitivity of all water-level and streamflow observations to changes in each parameter value during the calibration process. For the final calibrated parameter values, composite sensitivities computed by PEST (fig. 15) indicate that water levels and streamflows were most sensitive to the horizontal hydraulic conductivity of the upper bedrock aquifer, glacial sediments, and recharge. Less sensitive parameters included vertical hydraulic conductivity of aquifers, horizontal hydraulic conductivity of confining units, and riverbed leakance. Initial sensitivity analyses showed similar results and were used to guide selection of parameters for estimation; that is, high sensitivity to a parameter indicates that the calibration data (water levels and flows) provide sufficient information for constraining values for the parameter, and low sensitivity to a parameter indicates that the calibration data lack sufficient information to constrain the parameter. Therefore, parameters with low sensitivity were specified at reasonable values at the outset of parameter estimation or were directly tied to more sensitive parameters during the parameter-estimation process (fig. 15).

\section{Mass Balances}

Simulated model results indicate that recharge is the primary source of inflow to the groundwater-flow system in Pierce, Polk, and St. Croix Counties. Recharge accounted for 82 percent $\left(1,346\right.$ cubic feet per second $\left.\left[\mathrm{ft}^{3} / \mathrm{s}\right]\right)$ of all groundwater inflow to the three counties. The remainder consists of recirculated groundwater seepage from internal rivers and lakes ( $244 \mathrm{ft}^{3} / \mathrm{s}$, or about 15 percent of total inflow) and

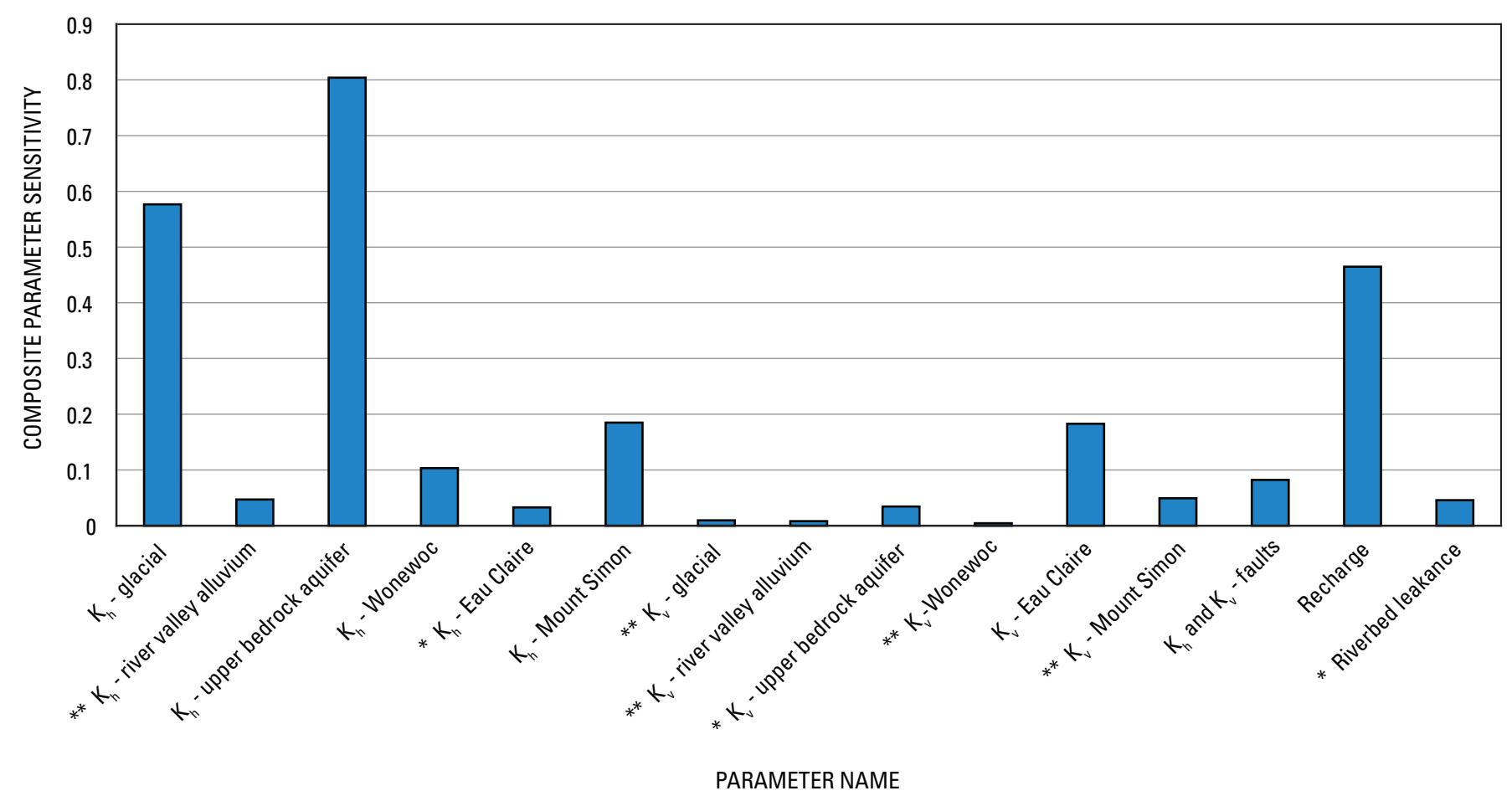

Figure 15. Composite sensitivities computed by PEST for parameters of the regional MODFLOW model of Pierce, Polk, and St. Croix Counties, Wisconsin. Sensitivities were computed independently for each parameter; no parameters were fixed or tied to other parameters for the final sensitivity calculations. ${ }^{*}$ indicates the value was specified during the calibration process; ${ }^{* *}$ indicates the ratio $\mathrm{K}_{\mathrm{h}}: \mathrm{K}_{\mathrm{v}}$ was specified as 100:1 during the calibration process; parameters without an asterisk were estimated during the calibration process; $\mathrm{K}_{\mathrm{h}^{\prime}}$, horizontal hydraulic conductivity; $\mathrm{K}_{\mathrm{v}^{\prime}}$ vertical hydraulic conductivity) 
horizontal flow through aquifers across the county boundaries $\left(61 \mathrm{ft}^{3} / \mathrm{s}\right.$, or about 4 percent of total inflow). Recirculated groundwater seepage from rivers and lakes is groundwater that previously entered a river or lake at an upstream location. In the three counties, seepage from rivers and lakes commonly occurs near waterfalls and dams where water levels change abruptly, and it also occurs on the downgradient (downstream) end of a lake or reservoir. These sources of groundwater were balanced by flow from the aquifers to rivers inside the three counties ( 85 percent or $1,397 \mathrm{ft}^{3} / \mathrm{s}$ ), to pumping wells (1 percent or $19 \mathrm{ft}^{3} / \mathrm{s}$ ), and outward flow across the county boundaries ( 14 percent or $235 \mathrm{ft}^{3} / \mathrm{s}$ ). Table 4 summarizes the mass-balance sources and sinks for the entire model domain and the individual counties. The mass-balance analysis indicates that the primary source of groundwater withdrawn by pumping wells in each county is water recharged within the county and is water that otherwise would have discharged to local rivers and lakes.

\section{Application of the Regional Model}

Simulations designed to address specific hydrologic questions can be run after models are calibrated. These simulations can include past and present conditions or future scenarios. Past and present conditions (1994-2004) are discussed in this section. Local refinements through the construction of inset models are also described for demonstration purposes.

\section{Groundwater-Flow Directions and Interaction with Surface Water}

Results from the regional model include simulated water levels, flow directions, and mass-balance interactions with surface-water features. Contours of simulated water levels are similar to water-table maps produced previously for the counties in that groundwater flow is perpendicular to the

Table 4. Mass-balance components for Pierce, Polk, and St. Croix Counties, Wisconsin, collectively and individually, and the entire model area.

[ $\mathrm{ft}^{3} / \mathrm{s}$, cubic foot per second. Percentages may not add to 100 because of rounding]

\begin{tabular}{|c|c|c|c|c|c|}
\hline \multirow{2}{*}{ Area } & \multirow{2}{*}{ Type of source or sink } & \multicolumn{2}{|c|}{ Groundwater inflow } & \multicolumn{2}{|c|}{ Groundwater outflow } \\
\hline & & $\left(\mathrm{ft}^{3} / \mathrm{s}\right)$ & (Percent of total) & $\left(\mathrm{ft}^{3} / \mathrm{s}\right)$ & (Percent of total) \\
\hline \multirow{4}{*}{$\begin{array}{l}\text { Combined Pierce, Polk, } \\
\text { and St. Croix Counties }\end{array}$} & Recharge & 1,346 & 82 & 0 & 0 \\
\hline & Streams and lakes & 244 & 15 & 1,397 & 85 \\
\hline & Flow across county borders & 61 & 4 & 235 & 14 \\
\hline & Well pumping & 0 & 0 & 19 & 1 \\
\hline \multirow{4}{*}{ Pierce County } & Recharge & 352 & 74 & 0 & 0 \\
\hline & Streams and lakes & 71 & 15 & 443 & 93 \\
\hline & Flow across county borders & 54 & 11 & 31 & 7 \\
\hline & Well pumping & 0 & 0 & 3 & 1 \\
\hline \multirow{4}{*}{ Polk County } & Recharge & 559 & 75 & 0 & 0 \\
\hline & Streams and lakes & 117 & 16 & 655 & 88 \\
\hline & Flow across county borders & 68 & 9 & 84 & 11 \\
\hline & Well pumping & 0 & 0 & 5 & 1 \\
\hline \multirow{4}{*}{ St. Croix County } & Recharge & 447 & 81 & 0 & 0 \\
\hline & Streams and lakes & 61 & 11 & 461 & 83 \\
\hline & Flow across county borders & 47 & 8 & 83 & 15 \\
\hline & Well pumping & 0 & 0 & 11 & 2 \\
\hline \multirow{4}{*}{ Entire model area } & Recharge & 4,527 & 81 & 0 & 0 \\
\hline & Streams and lakes & 882 & 16 & 5,184 & 93 \\
\hline & Flow across county borders & 147 & 3 & 154 & 3 \\
\hline & Well pumping & 0 & 0 & 219 & 4 \\
\hline
\end{tabular}


contours. However, simulated water levels from the regional model are further constrained in that the model must also account for all water that enters and exits the model, which is not a consideration for drawn water-table maps. Numerical particles of water can also be traced along flow paths in the model to illustrate differences in flow directions among vertically stacked aquifers. Figure 16 shows the path of several mathematical particles of water flowing downgradient, starting at the water table and flowing to discharge locations such as wells and rivers. Much of the water that recharges at the water table flows through the upper bedrock or sand and gravel aquifers and discharges to nearby rivers. Water that recharges in areas with steep vertical gradients moves into deep aquifers before returning to shallow aquifers near major groundwater sinks, such as the St. Croix and Mississippi Rivers. Groundwater flow velocities in the upper bedrock aquifer are expected to be variable because of the nature of flow through fractures and conduits in the Prairie $\mathrm{du}$ Chien Group and, to a lesser extent, in the Trempealeau and Tunnel City Groups. For example, Cobb (2007) measured a range of local velocities from about 12 to $340 \mathrm{ft} / \mathrm{d}$ through fractures in the Prairie du Chien Group at one location in St. Croix County. Groundwater in the upper aquifers is also younger than water in the deep aquifers. Flow paths through the deep sandstone aquifers are relatively longer, and velocities tend to be relatively slower because of the lower hydraulic conductivity and hydraulic gradients in the deep units.

Groundwater/surface-water interaction was evaluated by use of output from the calibrated regional model. Modeled discharge into each river cell was color-coded to show gaining and losing reaches (fig. 16). Groundwater discharges into all areas of the St. Croix and Mississippi Rivers, except immediately upstream from lock and dam 3 on the Mississippi River. Groundwater discharge into pools and lakes of the lower St. Croix and Mississippi Rivers generally is greatest along the shoreline, with decreasing rates of groundwater discharge toward the center of the pools; groundwater discharge into upland lakes also tends to occur primarily along the shoreline. Tributaries to the St. Croix and Mississippi Rivers show more complex transitions between gaining and losing reaches. Most river reaches gain water from the groundwater-flow system. Losing reaches tend to occur upstream from impoundments (the downstream shoreline of reservoirs) and along the downgradient shoreline of lakes.
The model was also used to evaluate vertical groundwater flow between layers in the model and to identify factors that influence vertical flow patterns (fig. 17). Groundwater flows downward between layers over much of the area because recharge to the water table induces downward pressure. Groundwater flows upward primarily near faults and large rivers. As represented in the model, faults appear to have relatively modest influence on regional horizontal and vertical flow patterns in all layers (small deflection in contours and modest correlation with areas of upward flow; fig. 17). Locally, however, faults may have substantial influence on groundwater flow, as illustrated by complex water levels in a nest of monitoring wells south of Afton, $\mathrm{MN}$, and distant from pumping centers (Minnesota unique well numbers 216161,216162 , and 216163). At this site, the 20 -year average water level measured in the Wonewoc Formation exceeds

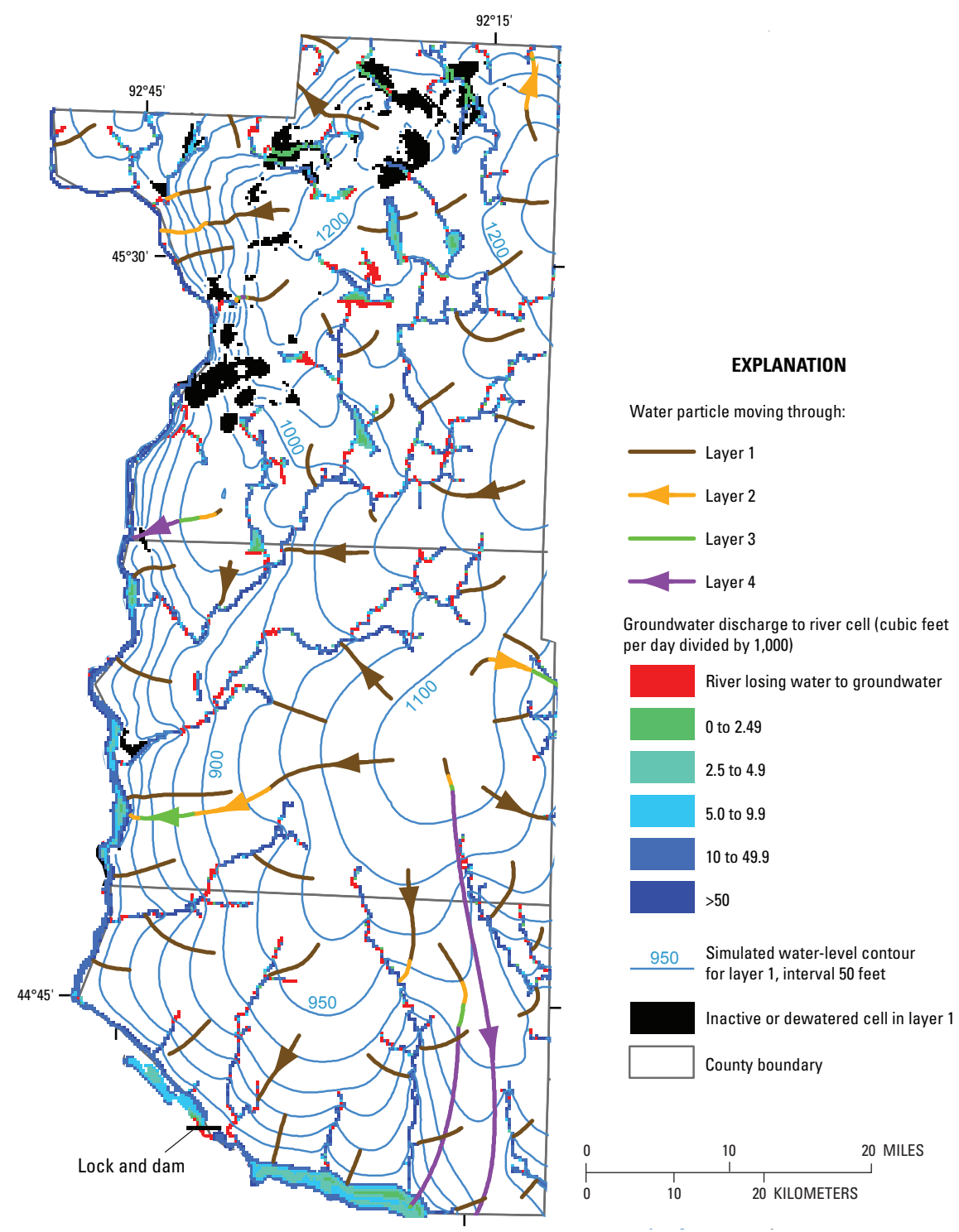

Figure 16. Simulated water-table elevation, particle flow paths from the water table, and groundwater/surface-water interaction in the regional groundwater-flow model, layer 1. 


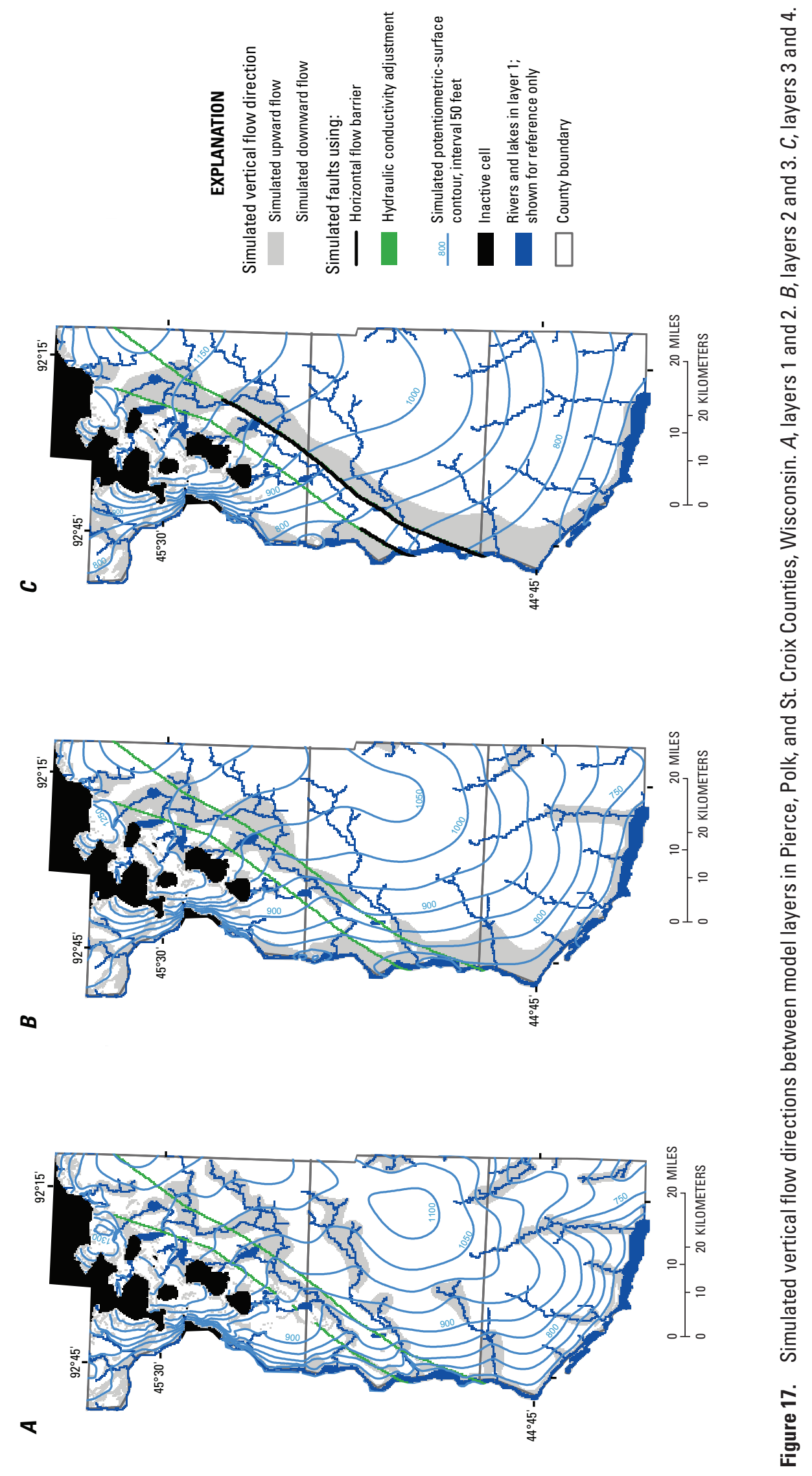


the average water levels measured in the underlying Mount Simon Formation and the overlying Tunnel City Group by about $21 \mathrm{ft}$ and $7 \mathrm{ft}$, respectively. Moreover, where the Mount Simon aquifer is adjacent to crystalline bedrock and simulated with the Horizontal Flow Barrier (HFB) Package (Hsieh and Freckleton, 1993) in layer 4 of the regional model, hydraulic damming occurs, which diverts groundwater upward over the crystalline rock and(or) horizontally along the faults as the water flows toward the St. Croix River.

Groundwater does not appear to cross between Wisconsin and Minnesota beneath the Mississippi and St. Croix Rivers in any of the four model layers. Specifically, simulated groundwater flow is upward below nearly the entire length of the Mississippi and St. Croix Rivers where the rivers border Pierce, Polk, and St. Croix Counties (fig. 17). In areas where all the groundwater is captured by the Mississippi and St. Croix Rivers, the rivers function as fully penetrating hydraulic boundaries to groundwater flow. The flowsystem divide underneath these large rivers may not be stationary, however. It is important to note that groundwater withdrawal can change the effectiveness of hydraulic boundaries (for example, Strack and others, 1987; Feinstein and others, 2005). Smaller tributary rivers, such as the Apple, Willow, Kinnickinnic, and Rush Rivers, have gaining and losing reaches and appear to be partially penetrating hydraulic boundaries. These tributaries induce upward flow from the Wonewoc aquifer and Eau Claire confining unit, but have less influence on the Mount Simon aquifer, especially in headwater areas (fig. 17). Influence of the Apple River (fig. 1) on vertical flow is complicated by nearby faulting.

\section{Predevelopment Conditions Compared to Present (1994-2004) Conditions}

The calibrated regional model can be used to address the effects of pumping (past, present, and future) on the groundwater resource. In this study, predevelopment conditions were compared to present pumping conditions. The predevelopment conditions were simulated by using the calibrated model input and excluding pumping wells. Changes in groundwater levels between predevelopment and present conditions due to the construction or removal of dams and reservoirs were not evaluated; that is, no river or lake elevations were changed from the calibrated model for the predevelopment simulation.
The comparison of model simulations shows declines in groundwater levels where high-capacity wells are grouped in discrete clusters, but few effects were observed in other areas of the counties where pumping wells are much more dispersed and discharge at lower rates (figs. 18 and 19). With current pumping conditions, the simulated water table in the upper unconfined aquifer (model layer 1) has declined by less than $2 \mathrm{ft}$ from predevelopment levels throughout most of the three-county area except near local pumping centers, such as one near Clear Lake in Polk County with a maximum decline of about $8 \mathrm{ft}$ (fig. 18).

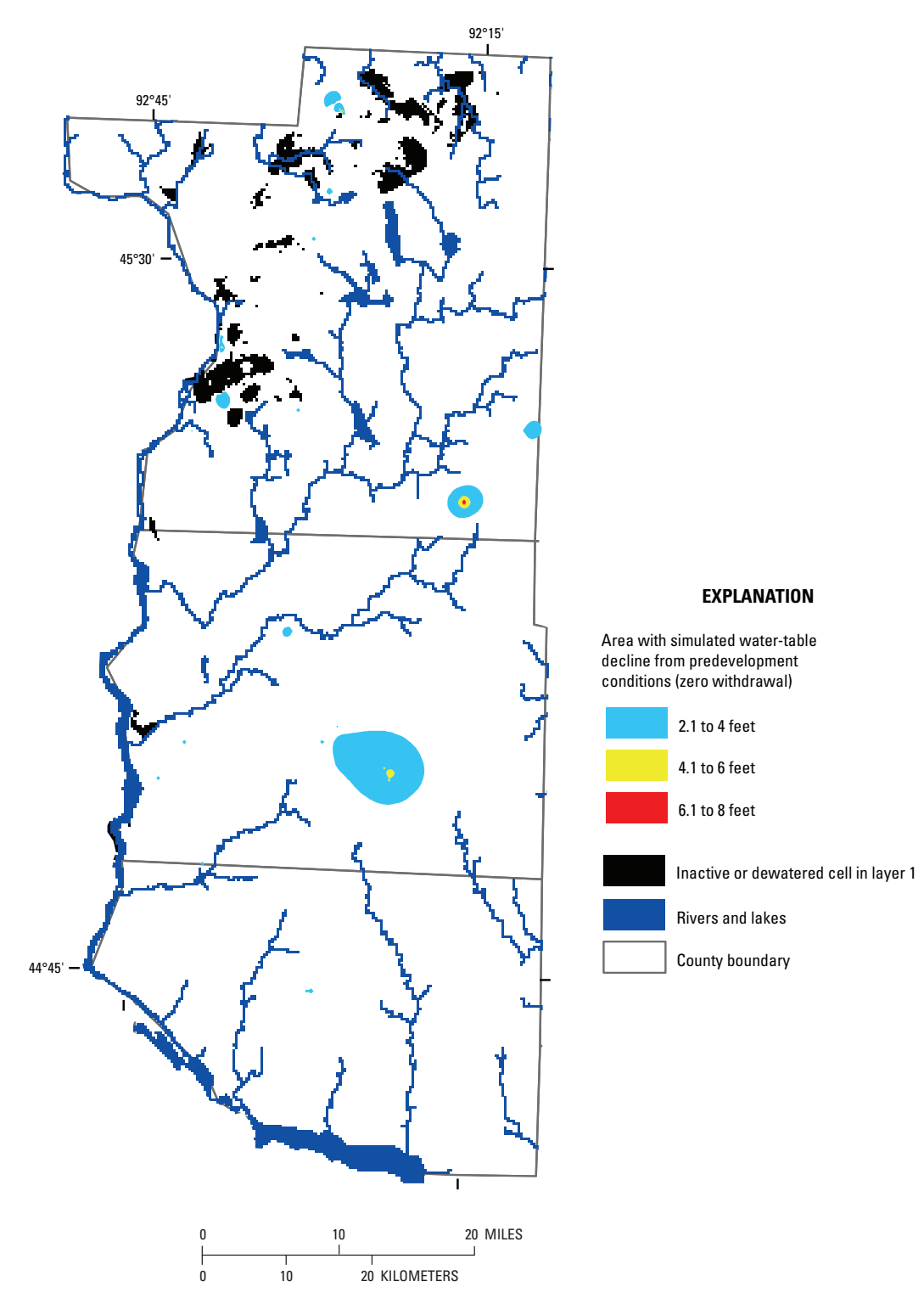

Figure 18. Simulated water-table decline (layer 1 ) from predevelopment to present (1994-2004) water-use conditions in Pierce, Polk, and St. Croix Counties, Wisconsin. 


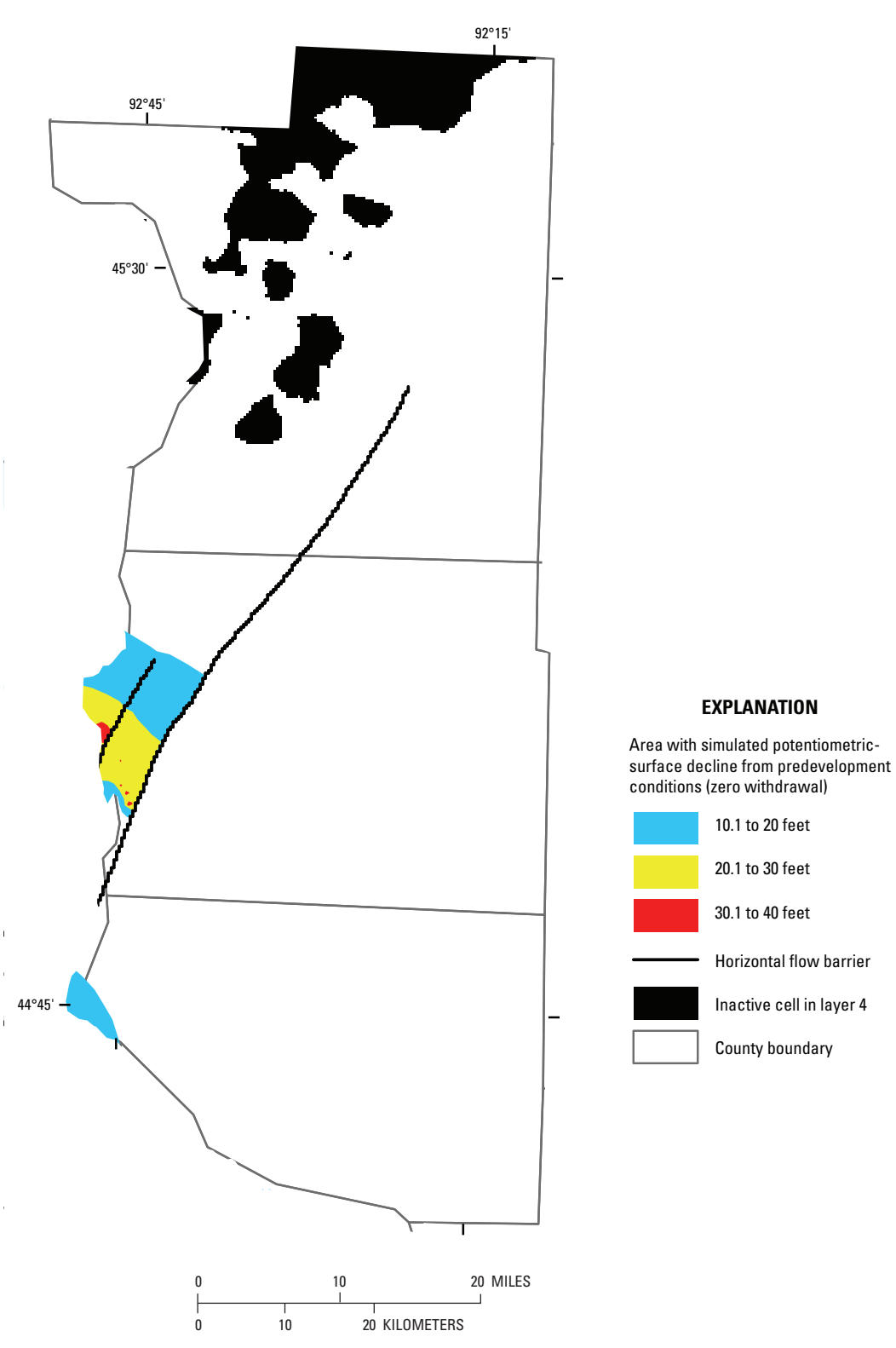

Figure 19. Simulated potentiometric-surface decline in the Mount Simon aquifer (layer 4) from predevelopment to present (1994-2004) water-use conditions in Pierce, Polk, and St. Croix Counties, Wisconsin.

The simulated potentiometric surface for the Mount Simon aquifer (model layer 4) has declined by more than $10 \mathrm{ft}$ from predevelopment levels in western Pierce and St. Croix Counties (fig. 19), with a maximum decline of about $40 \mathrm{ft}$ near the city of Hudson, WI. The decline in the potentiometric surface appears to be associated with pumping from the deep aquifer below Hudson, combined with pumping from nearby communities in Minnesota. Near Hudson, the simulated decline may be exacerbated by the representation of large regional faults, which tend to isolate the aquifer to some extent from the surrounding flow system. Further, where the overlying shale-rich Eau Claire confining unit has not been removed by erosion (most of the study area; fig. 7), leakage from overlying aquifers is impeded, thus enhancing the potential for drawdown in the Mount Simon aquifer regardless of proximity to large rivers.

\section{Demonstration Simulations of Local- Scale Groundwater Flow}

The regional model is useful for understanding groundwater flow at a regional scale and also for use as a framework from which local-scale investigations can be initiated. The process of using the regional model as a framework is demonstrated for one location in each of the three counties. These inset models were developed to demonstrate the utility of this approach and additional model capabilities rather than to answer a specific question. Moreover, the demonstration inset models were not explicitly calibrated to data that are commensurate with the type of simulated results produced by the models. Thus, results from the demonstration models, as presented in this report, incur greater uncertainty than results shown for the regional model and are not suited for decisionmaking. Nonetheless, the demonstration models could be refined in the future to address specific questions, provided that data pertinent to the refined objectives are included.

\section{Telescopic Mesh Refinement}

Three demonstration inset models were extracted from the regional MODFLOW model (fig. 1) by use of a telescopic mesh refinement (TMR) approach, following the methods of Ward and others (1987) and implemented in Groundwater Vistas (Rumbaugh and Rumbaugh, 2007). Results from the regional model were used to assign constant-flux boundary conditions along the perimeter of each inset model. Eventual changes to parameter values in the inset models subsequently were incorporated into copies of the regional model that were dedicated to the TMR process for each inset model, and constant-flux boundary conditions were reextracted. This manual coupling was performed to improve the perimeter boundary fluxes for the demonstration inset models; future inset models would benefit from automated coupling of the boundary conditions with the regional model through the new Local Grid Refinement (LGR) method for MODFLOW (Mehl and Hill, 2005, 2007). In addition, some distance between the boundaries of the inset models and the area of interest was desired to ensure minimal influence of boundary conditions on simulated results. This distance was estimated by means of a characteristic leakage length (Haitjema, 2006) 
estimated from properties of aquifers and confining units originally combined into layer 1 of the

regional model.

The grid spacing of $1,000 \mathrm{ft}$ by $1,000 \mathrm{ft}$ for the regional model was refined to about $200 \mathrm{ft}$ by $200 \mathrm{ft}$ for the Pierce and Polk County inset models and to $250 \mathrm{ft}$ by $250 \mathrm{ft}$ for the St. Croix County inset model. Thus, every cell from the regional model is represented by about 25 cells in the Pierce and Polk County inset models and by 16 cells in the St. Croix County inset model. As a result of the smaller grid spacing, surface-water features and the hydraulic-head distribution were simulated with more detail in the inset models. A second refinement was the conversion of some streams from the MODFLOW River Package (McDonald and Harbaugh, 1988) to more sophisticated Streamflow Routing Packages (Prudic, 1989; Niswonger and Prudic, 2005). The Streamflow Routing Packages track base-flow gains and losses along the stream length and also limit the amount of water a stream can lose to the aquifer by the amount of water captured in upstream reaches. The simpler River Package was used to simulate streams outside of the area of interest. The river and stream geometries also were refined for each inset model. Hydraulic properties of streambed and lakebed sediments (leakance) were retained from the regional model, whereas grid-specific values were adjusted to match the smaller cell size.

Another important change to the construction of the demonstration inset models was refinement of the top layer of the regional model. The top layer of the regional model was split at the estimated elevation of the contact between the Jordan Sandstone and the Prairie du Chien Group in all three inset models. A georeferenced grid (Michael Cobb, University of Wisconsin, written commun., 2006) representing an interpolated elevation of this geologic contact was used for the St. Croix and Pierce County inset models. No similar grid was available for the Polk County inset model; instead, the top layer was split into two equal halves, which roughly correspond with the location of this contact in the Pierce and St. Croix County inset models.

In addition to changes in model construction, some model parameter values were adjusted during the TMR model refinement (table 5). As part of the TMR routine, properties of the regional model were directly translated for the Wonewoc, Eau Claire, and Mount Simon units. Properties of the new upper layers were adjusted to improve simulation of local heads and base flows. Parameters were adjusted first for the St. Croix County inset model because there was relatively more available data than for the Pierce and Polk County demonstration models. All parameter values from the St. Croix County model were used for the Pierce County inset model except the value for recharge, which was specified from the regional model, and horizontal hydraulic conductivity of the uppermost bedrock layer, which was refined by use of local water-level and streamflow data. Parameter values in the Polk County inset model were assigned directly from the Pierce County model. Additional refinements specific to the individual demonstration inset models are described below.

\section{Construction and Simulation of the St. Croix County Demonstration Inset Model}

The purpose of the St. Croix County inset model was to demonstrate simulation of groundwater/lake-water interaction for Twin Lakes near Roberts. This was done by means of the MODFLOW Lake Package (LAK; Merritt and Konikow, 2000), which computes lake stage on the basis of a hydrologic budget that includes surface processes as well as groundwater inflow and outflow. In addition to the refinements described above, the St. Croix County model grid was further refined above the Prairie du Chien-Jordan contact. Use of the Lake Package required that the lakes occupy and replace an aquifer, thereby removing the aquifer from the model solution at the lake location. Because the lakes are not regional features and their connection to the groundwater-flow system was unclear, it was preferable that the regional Prairie du Chien Group remain intact in the model. Thus, a 45 -ft-thick sequence of local glacial material (based on well-construction-report (WCR) data near the village of Roberts) was split from the top of the Prairie du Chien layer. Further, water-level data from WCRs indicate that the regional water table is in the Prairie du Chien Group near Twin Lakes. As a consequence, the local glacial aquifer was simulated only in the immediate vicinity of Twin Lakes, as guided by topographic ridges. Thus, East and West Twin Lakes were simulated together as a groundwater seepage lake (no surface inlet or outlet) in a local glacial aquifer above the regional water table in the Prairie du Chien Group. All streams were simulated at the surface of the Prairie du Chien Group (layer 2) to ensure proper connection with the regional water table.

Simulated sources of water to Twin Lakes included average annual precipitation (33.14 in/yr from 1993 to 2002; Kenneth Schreiber, Wisconsin Department of Natural Resources, written commun., 2006), augmentation from a wastewater-treatment plant (72 acre-feet per year or 23.5 Mgal/yr; Schreiber, 1995), and computed groundwater inflow. Overland flow was assumed to be negligible given the lack of surface streams in the area. Water leaves the lakes through direct evaporation and leakage into the groundwaterflow system, which was computed by the model. There are no surface-water outlets from the lakes.

Hydraulic conductivity, recharge, and direct evaporation from the lakes were adjusted in the St. Croix County inset model to improve simulation of the stage of Twin Lakes and local water levels (table 5). Horizontal and vertical hydraulic conductivities for the Mount Simon, Eau Claire, and Wonewoc Formations were specified from the regional model. Horizontal hydraulic conductivities for a new layer representing the Jordan Formation, St. Lawrence Formation, and Tunnel City Group (lower part of the upper bedrock aquifer in the regional model) were estimated from average thicknesses (Mudrey and others, 1987) and reasonable conductivities (table 1; Ray Wuolo, Barr Engineering Company, written commun., May 2007). Horizontal and vertical hydraulic conductivity 
Table 5. Parameter values used for the demonstration inset models.

[ft/d, foot per day; n/a, not applicable or not simulated; in/yr, inch per year; [ft/d]/ft, foot per day per foot; Mgal/yr, million gallons per year]

\begin{tabular}{|c|c|c|c|}
\hline Hydrogeologic unit & St. Croix County model & Pierce County model & Polk County model \\
\hline \multicolumn{4}{|c|}{ Horizontal hydraulic conductivity (ft/d) } \\
\hline Local sand and gravel aquifer & 12 & $\mathrm{n} / \mathrm{a}$ & $\mathrm{n} / \mathrm{a}$ \\
\hline Regional alluvial aquifer & $90^{\mathrm{a}}$ & $90^{\mathrm{a}}$ & $90^{\mathrm{a}}$ \\
\hline Prairie du Chien aquifer & 207 & 19 & $19^{\mathrm{a}}$ \\
\hline Jordan-St. Lawrence-Tunnel City unit & $10^{\mathrm{a}}$ & $20^{\mathrm{a}}$ & $10^{\mathrm{a}}$ \\
\hline Wonewoc aquifer & $11^{\mathrm{a}}$ & $11^{\mathrm{a}}$ & $11^{\mathrm{a}}$ \\
\hline Eau Claire confining unit & $2^{\mathrm{a}}$ & $2^{\mathrm{a}}$ & $2^{\mathrm{a}}$ \\
\hline Mount Simon aquifer & $7^{\mathrm{a}}$ & $7^{\mathrm{a}}$ & $7^{\mathrm{a}}$ \\
\hline Faults & $.09^{\mathrm{a}}$ & $\mathrm{n} / \mathrm{a}$ & $\mathrm{n} / \mathrm{a}$ \\
\hline \multicolumn{4}{|c|}{ Vertical hydraulic conductivity (ft/d) } \\
\hline Local sand and gravel aquifer & $0.12^{\mathrm{b}}$ & $\mathrm{n} / \mathrm{a}$ & $\mathrm{n} / \mathrm{a}$ \\
\hline Regional alluvial aquifer & $.9^{\mathrm{a}}$ & $0.9^{\mathrm{a}}$ & $0.9^{\mathrm{a}}$ \\
\hline Prairie du Chien aquifer & .017 & $.017^{\mathrm{a}}$ & $.017^{\mathrm{a}}$ \\
\hline Jordan-St. Lawrence-Tunnel City unit & $.005^{\mathrm{a}}$ & $.005^{\mathrm{a}}$ & $.005^{\mathrm{a}}$ \\
\hline Wonewoc aquifer & $.11^{\mathrm{a}}$ & $.11^{\mathrm{a}}$ & $.11^{\mathrm{a}}$ \\
\hline Eau Claire confining unit & $.00009^{\mathrm{a}}$ & $.00009^{\mathrm{a}}$ & $.00009^{\mathrm{a}}$ \\
\hline Mount Simon aquifer & $.07^{\mathrm{a}}$ & $.07^{\mathrm{a}}$ & $.07^{\mathrm{a}}$ \\
\hline Faults & $.09^{\mathrm{a}}$ & $\mathrm{n} / \mathrm{a}$ & $\mathrm{n} / \mathrm{a}$ \\
\hline \multicolumn{4}{|c|}{ Other parameters } \\
\hline Recharge (in/yr) & 16.8 & $8.2^{\mathrm{a}}$ & $8.2^{\mathrm{a}}$ \\
\hline Direct precipitation on lake (in/yr) & $33.14^{\mathrm{a}}$ & $\mathrm{n} / \mathrm{a}$ & $\mathrm{n} / \mathrm{a}$ \\
\hline Direct evaporation from lake (in/yr) & 32.12 & $\mathrm{n} / \mathrm{a}$ & $\mathrm{n} / \mathrm{a}$ \\
\hline Lakebed leakance $([\mathrm{ft} / \mathrm{d}] / \mathrm{ft})$ & $1.9 \mathrm{e}^{-2}$ & $\mathrm{n} / \mathrm{a}$ & $\mathrm{n} / \mathrm{a}$ \\
\hline Lake augmentation (Mgal/yr) & $23.5^{\mathrm{a}}$ & $\mathrm{n} / \mathrm{a}$ & $\mathrm{n} / \mathrm{a}$ \\
\hline
\end{tabular}

of the karst Prairie du Chien Group and horizontal hydraulic conductivity of the local glacial aquifer were adjusted by use of PEST to improve the match to target water levels and flows; the $\mathrm{K}_{\mathrm{h}}: \mathrm{K}_{\mathrm{v}}$ ratio of the local glacial aquifer was specified at 100:1. In addition, evaporation from the lake surface, recharge, and lakebed leakance were adjusted by use of PEST (table 5). Observation data used to constrain parameter values included the average combined stage of East and West Twin Lakes from May to October 2006 (966.41 ft; Keith Solimar, Town of Warren Groundwater Citizens Advisory Committee, written commun., October 2006), a synoptic base-flow measurement on the Kinnickinnic River at 140th Street near Roberts, water-table elevation estimates in WCR wells from the regional model (assigned to the Prairie du Chien Group, layer 2), water levels from minipiezometers around the lakes installed and measured in October 2003 (Kenneth Schreiber, Wisconsin Department of Natural Resources, written commun., July 2006), and water levels of local ponds surveyed in October 2006 with a differential global positioning system.
Base-flow and water-level residuals for the local WCR targets were improved over those in the regional model (average error of WCR targets in the inset model is $-9.9 \mathrm{ft}$; average error of the same targets in the regional model is $-26.8 \mathrm{ft}$; figs. 20 and $11 B$ ). An increase in the simulated hydraulic conductivity of the Prairie du Chien Group (table 5) lowered simulated water levels compared with the regional model (figs. 20 and 11B). An increase in the simulated recharge (within the range simulated in karst-prone areas of Washington County, MN; Barr Engineering Company and Washington County, 2005) improved simulated base flow in the Kinnickinnic River at 140th Street (measured, $8.5 \mathrm{ft}^{3} / \mathrm{s}$; simulated, $8.2 \mathrm{ft}^{3} / \mathrm{s}$ ) compared with the regional model (simulated, $7.2 \mathrm{ft}^{3} / \mathrm{s}$; table $3 B$ ). Although detailed calibration was outside the scope of the demonstration modeling, it appears that the simulated water table for the demonstration model is appreciably improved by the use of more detailed hydrostratigraphy and that future models in or near areas with banded residuals in the regional model would also likely be improved by refined layering. 


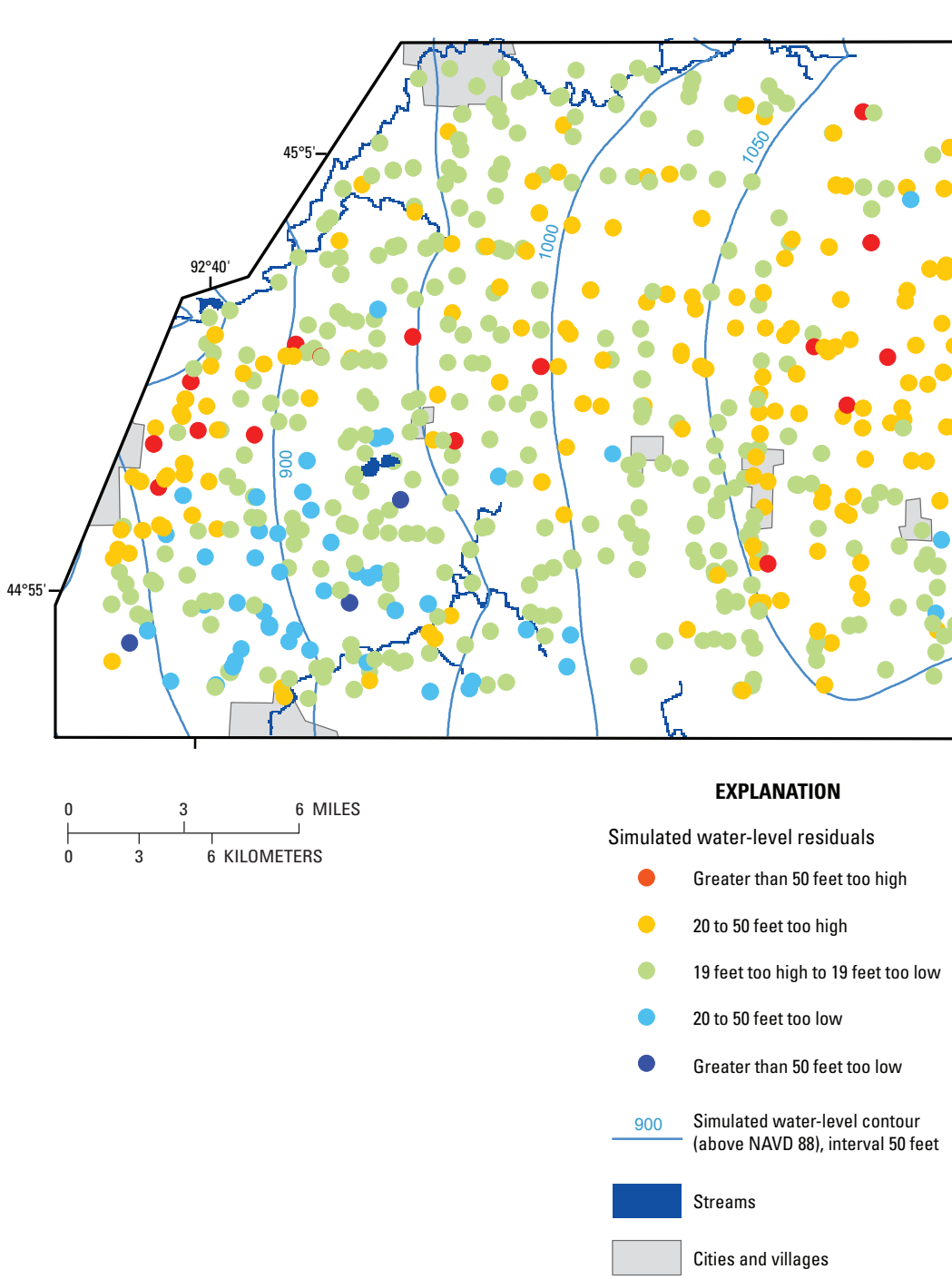

Figure 20. Simulated water-table elevation and water-level residuals for the St. Croix County, Wisconsin, demonstration inset model, layer 2.

\section{Results of Simulating Groundwater/ Lake-Water Interaction near Twin Lakes near Roberts, St. Croix County}

Simulation of groundwater/lake-water interaction for Twin Lakes indicates that groundwater inflow and outflow represent about 5 and 20 percent, respectively, of the total lake-water budget (table 6). Precipitation and evaporation, representing about 85 and 80 percent, respectively, of the total lake-water budget, dominate the lake budget and are likely to be important factors controlling the lake stage. Augmentation from a wastewater-treatment plant accounts for the remaining 10 percent of water entering the lake. Overland runoff was assumed to be negligible and therefore was not simulated. Similar to regional groundwater-flow directions, groundwater in the local glacial aquifer near Twin Lakes flows from the northeast to the southwest (fig. 21). Likewise, groundwater inflow to the lakes is simulated along the eastern shoreline of East Twin Lake; flow is simulated out of the lakes and into the aquifer across the remainder of the lake area, but predominantly along the western shoreline of West Twin Lake.

Application of the demonstration model of groundwater/lake-water interaction near Twin Lakes near Roberts, WI, could be enhanced through a focused field investigation of local hydraulic gradients and water-budget components for the lake. Calibrating the model to these new data would decrease uncertainty in simulated results. Calibrated results could be used to (1) evaluate influences from climatic variability (seasonal to decadal) and augmentation on lake-water levels, and (2) estimate individual components of a nutrient budget for the lakes when combined with water-quality data.

Table 6. Simulated mass-balance components for Twin Lakes, St. Croix County, Wisconsin.

$[\approx$, approximately. Percentages have been rounded to indicate level of confidence]

\begin{tabular}{lcc}
\hline \multicolumn{1}{c}{ Type of source or sink } & $\begin{array}{c}\text { Inflow to Twin Lakes } \\
\text { (percent of total) }\end{array}$ & $\begin{array}{c}\text { Outflow from } \\
\text { Twin Lakes } \\
\text { (percent of total) }\end{array}$ \\
\hline Direct precipitation on the lakes & $\approx 85$ & 0 \\
Direct evaporation from the lakes & 0 & $\approx 80$ \\
Surface-water runoff or streamflow & 0 & 0 \\
Augmentation (effluent from a wastewater-treatment plant) & $\approx 10$ & 0 \\
Groundwater flow & $\approx 5$ & $\approx 20$ \\
\hline
\end{tabular}




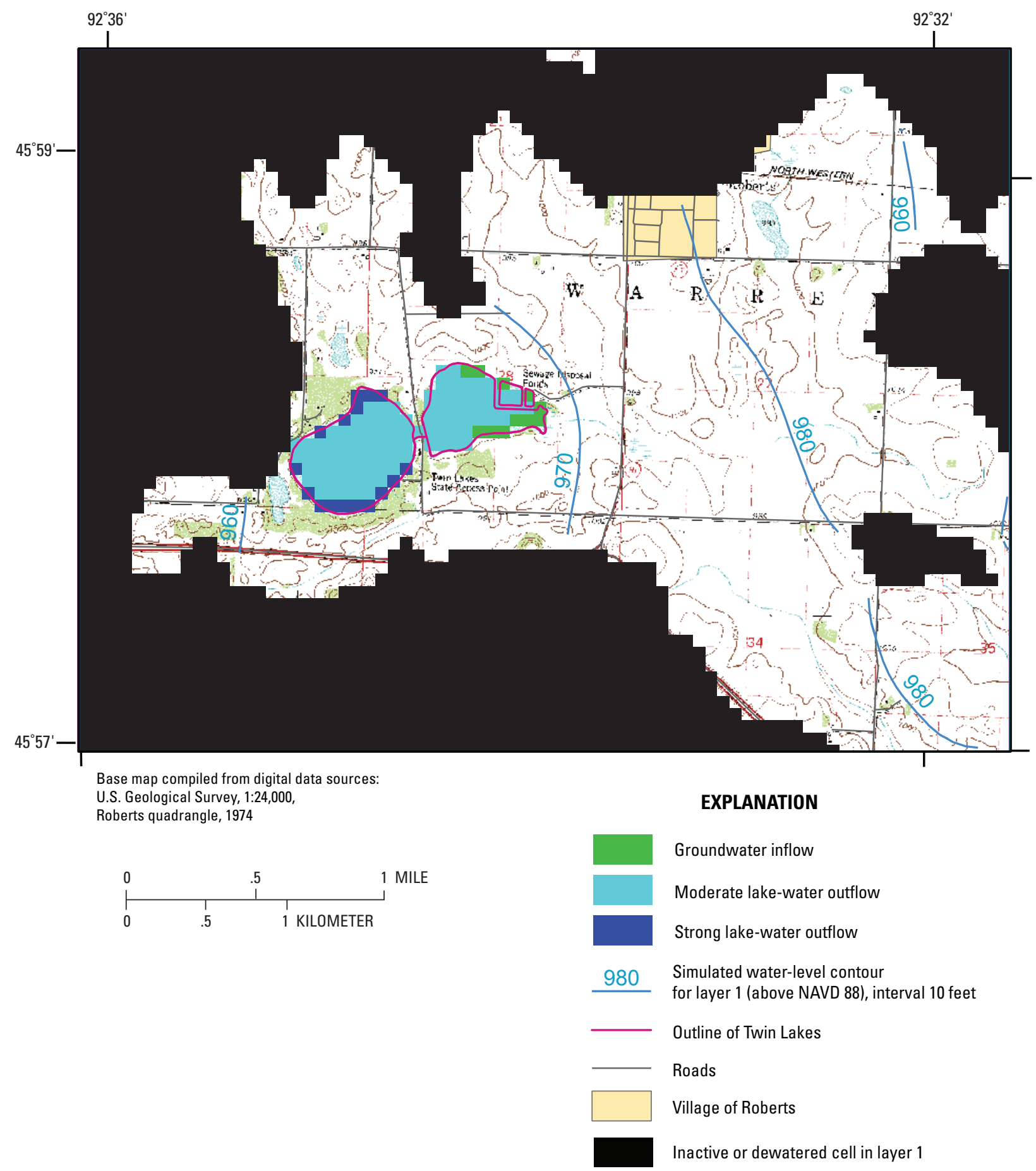

Figure 21. Simulated groundwater/lake-water interaction near Twin Lakes near the village of Roberts, Wisconsin, from the St. Croix County demonstration model, layer 1. Topographic map background shown for reference.

\section{Construction and Simulation of the Pierce County Demonstration Inset Model}

The purpose of the Pierce County inset model was to demonstrate the delineation of areas contributing groundwater to streams in western Pierce County by means of a groundwater-flow model. The model grid was refined as described in the "Telescopic Mesh Refinement" section. River geometries from the regional model were refined, and the Kinnickinnic and Big Rivers were simulated by use of a Streamflow Routing Package (Niswonger and Prudic, 2005). Hydraulic conductivities for the Pierce County inset model were derived from the regional model and the St. Croix County inset model (table 5), with two exceptions (1) the local glacial aquifer 
used to encompass Twin Lakes was not simulated because it represented a local perched aquifer of limited extent, and (2) horizontal hydraulic conductivity for the Prairie du Chien Group was adjusted with PEST, using local WCR and base-flow data along the Kinnickinnic River. Recharge was specified at the rate calibrated for the regional model.

Areas contributing recharge to streams were estimated by tracing mathematical particles of water from the water table to a discharge location (stream or well) by means of the USGS code MODPATH (Pollock, 1994). All particles were set to discharge to weak sinks (particles are considered captured as soon as they enter a cell containing a sink such as a stream). The tracking procedure was used to identify the starting location of all particles that ultimately discharged to individual stream segments.

\section{Results of Simulating Sources of Groundwater to Streams in Western Pierce County}

Areas simulated as contributing recharge to streams (fig. 22) locally surround individual streams and extend upgradient from the stream toward local and regional groundwater divides. The contributing area for the Big River is entirely within the local demonstration area; contributing areas for all other simulated streams extend beyond the inset-model domain. The contributing area for the Big River may be affected by dry-cell artifacts near its confluence with the Mississippi River, yet it shows a narrowing pattern near the mouth of the river that is similar to the contributing area for the Kinnickinnic River at the confluence with the St. Croix River.

Contributing areas illustrate the area over which recharge to the water table sustains base flow in the receiving stream. The area is proportional to the amount of simulated groundwater discharge to the stream given uniform areal recharge over the model domain; that is, stream reaches that discharge large quantities of base flow have large contributing areas; stream reaches with little base flow have small contributing areas. In addition, the water level of the St. Croix and Mississippi Rivers are the lowest levels in the area, so these regionally significant rivers capture all groundwater that is not captured upgradient by tributary streams, such as the Kinnickinnic and Big Rivers.

Finally, the groundwater-contributing areas can be compared with surface watersheds (fig. 22). The groundwater-contributing areas for the regional-scale Kinnickinnic and Trimbelle Rivers are of similar size and shape as their surface watersheds within the Pierce County demonstration model domain, but they do not necessarily coincide locally. For the Big River, the groundwater-contributing area is substantially smaller than its surface watershed because the river is ephemeral throughout much of the headwater area; that is, ephemeral streams flow only during flood events caused by surface-water runoff. Precipitation that infiltrates and recharges the water table in areas with ephemeral streams will flow beneath the ephemeral stream channel and discharge downstream to perennial segments of the Big River or discharge to the Mississippi River. It is also important to note that surface watershed boundaries are determined from static topographic features. Groundwater-contributing areas, on the other hand, are bound by hydraulic divides that can vary seasonally or shift systematically with the introduction of a hydrologic stress, such as well pumping.

Application of the Pierce County demonstration model could be enhanced by calibrating to measurements of base flow along the Big River. Such measurements would decrease

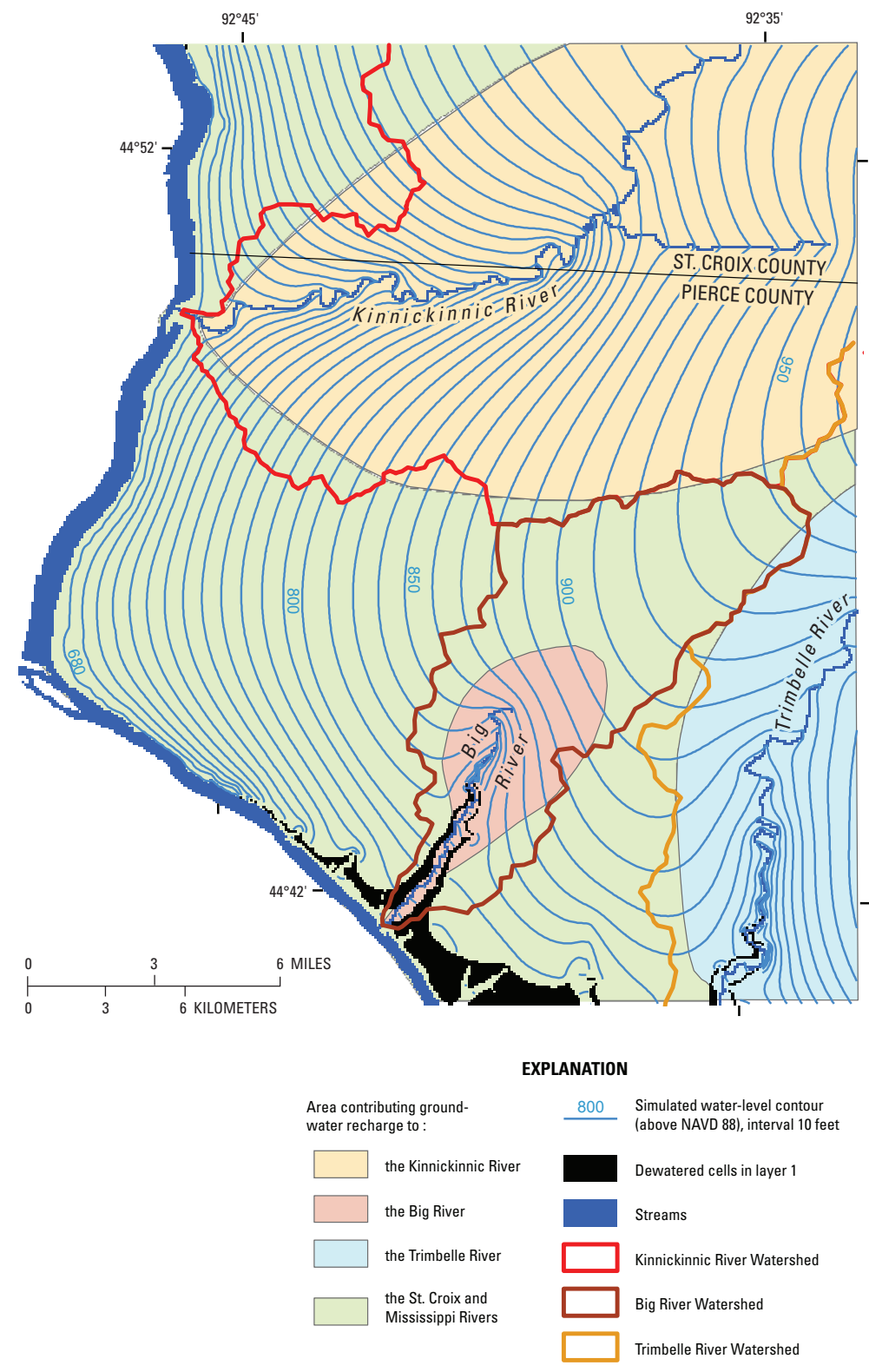

Figure 22. Simulated areas contributing groundwater recharge to rivers in western Pierce County, Wisconsin. 
uncertainty pertaining to the river's contributing area, which is proportional to the local distribution of recharge rates. The model could also be used to evaluate contributing areas to wells. Simulated groundwater traveltimes to wells and streams would benefit from local field investigations of aquifer and confining unit hydraulic properties, including flow rates through fractures and conduits over a range of scales.

\section{Construction and Simulation of the Polk County Demonstration Inset Model}

The purpose of the Polk County inset model was to demonstrate the influence of seasonal variability and systematic withdrawals on base flow in a small stream near an area experiencing rapid urban development. Seasonal variability was simulated on a monthly basis by distributing the annual recharge rate from the regional model into 12 monthly stress periods. Results from a coupled transient groundwater and surface-water model of a similarly sized stream in south central Wisconsin (Steuer and Hunt, 2001) were used to estimate monthly recharge as a percentage of average annual recharge over a 5-year simulation period (1994 to 1998). These monthly percentages were multiplied by the calibrated recharge rate for the regional model to produce 1 year of monthly recharge estimates for the Polk County inset model. The monthly recharge estimates were repeated 10 times to produce a dynamic cyclic simulation of a hypothetical 10-year period. Similar to the other county inset models, all stream geometries from the regional model were refined, and Osceola Creek was simulated by use of a Streamflow Routing Package (Prudic, 1989). Hydraulic conductivities for the Polk County inset model were derived, without modification, from the Pierce County inset model (table 5) because no local base-flow data were available.

An initial steady-state simulation was done with a version of the demonstration model that allowed cells in the model to convert between confined and unconfined conditions and potentially dewater. To facilitate convergence of the transient solution, dewatered cells from the steady-state solution were set inactive and all layers were specified as confined, with the simulated water table representing the top of layer 1. Specific storage $\left(3 \times 10^{-7}\right)$ was assigned to layers 2 through 5 on the basis of work by Feinstein and others (2005) in southeastern Wisconsin. This value is within the range of values reported by Miller and Delin (1993) for southeastern Minnesota and by Young (1992) for the northern Midwest. Specific yield, which represents storage properties of unconfined aquifers, was used to simulate aquifers in the top layer of the model. Values ranging from 10 to 30 percent were used and were based on typical values for sedimentary material (Johnson, 1967).

Current and predevelopment pumping conditions were also compared for this transient demonstration. Current conditions were simulated by applying the average pumping rates used for the regional model to all stress periods. Predevelopment conditions were simulated by removing all withdrawal wells from the inset model and the regional model before extracting boundary conditions. Thus, a regional predevelopment simulation was the source of boundary conditions for the Polk County predevelopment inset model simulation. Simulated base flow in Osceola Creek was quantified for a downstream reach near State Highway 35 (segment 13, reach 8).

\section{Results of Simulating Transient Streamflow in Osceola Creek, Polk County}

Simulation of seasonal base flow in Osceola Creek is shown for five hypothetical years in figure 23. The results illustrate how changes in base flow can be influenced by seasonal processes, such as recharge, and also by a systematic sink to the system, such as a constant rate of well withdrawal; that is, the seasonality of simulated base flow is the result of simulating recharge as a dynamic cyclic function, whereas the difference in base flow between the predevelopment scenario and the present conditions simulation is the result

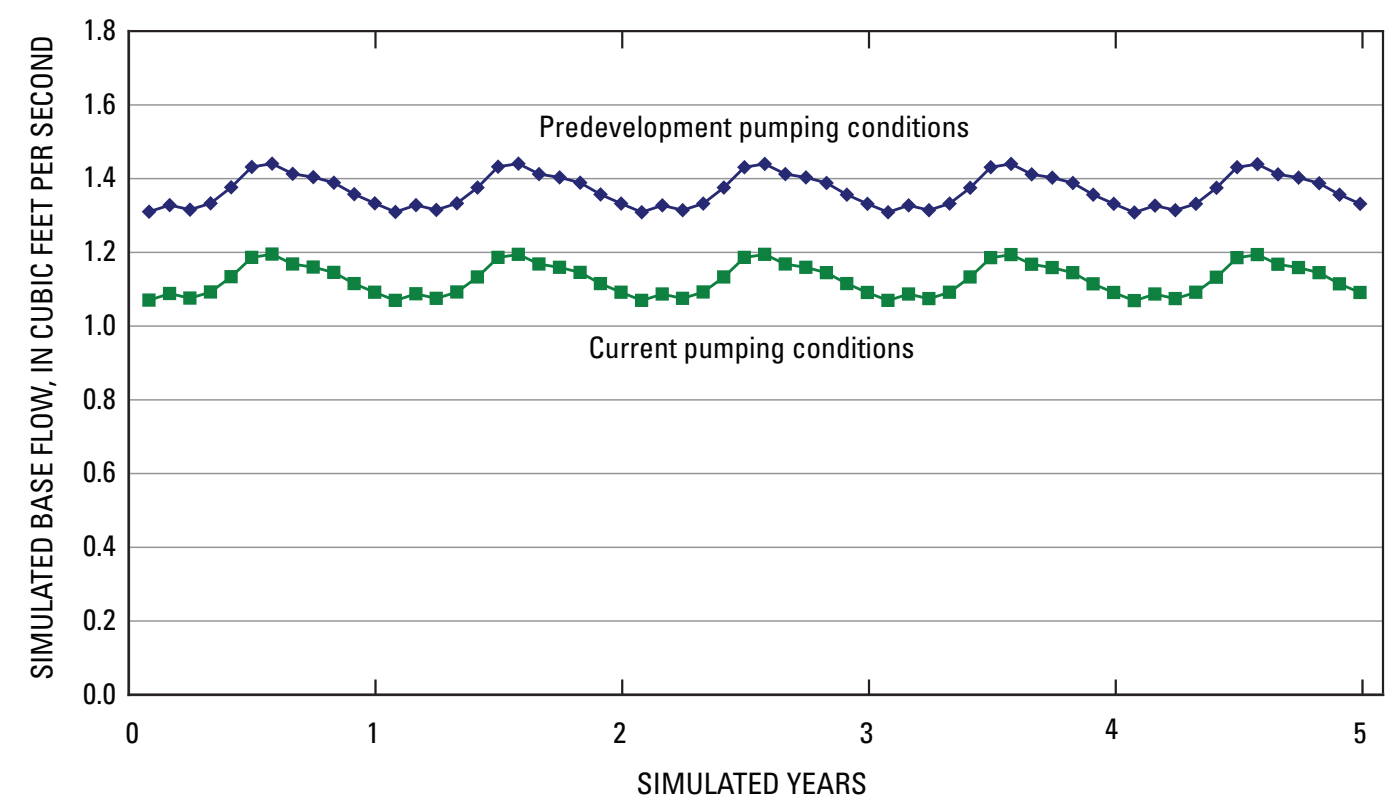

Figure 23. Simulated base flow in Osceola Creek, Polk County, Wisconsin, for predevelopment and present (1994-2004) pumping conditions. Simulated base flow does not include overland runoff, which increases annual streamflow variability beyond what is simulated for base flow alone. 
of eliminating wells that withdraw water at a constant rate. Although simplifications have been made in the model for these seasonal and static functions, natural systems would be expected to respond in a similar, albeit somewhat more complex, pattern.

Simulated groundwater-flow patterns near Osceola Creek (fig. 24) illustrate that groundwater discharge into Osceola Creek is greatest in the headwater area near Osceola Lake. Shortly downstream from 248th Street, Osceola Creek begins to lose water to the groundwater-flow system, as indicated by contour lines that bend in the downstream direction. Increased groundwater withdrawal has the potential to decrease water levels and potentially increase streamflow leakage out of the stream and into the groundwater-flow system near Osceola.
Application of the demonstration model of transient groundwater flow near Osceola Creek could be enhanced by calibrating to long-term measurements of base flow along Osceola Creek. Estimates of local aquifer-storage properties and seasonal recharge rates by use of one of the techniques described by Scanlon and others (2002) would also improve understanding of the system. Calibrating the model against these data could reduce uncertainty in simulating the mean and variability of base flow in the creek. Projected changes in recharge also could be incorporated into the model to evaluate potential effects on base flow in the creek.

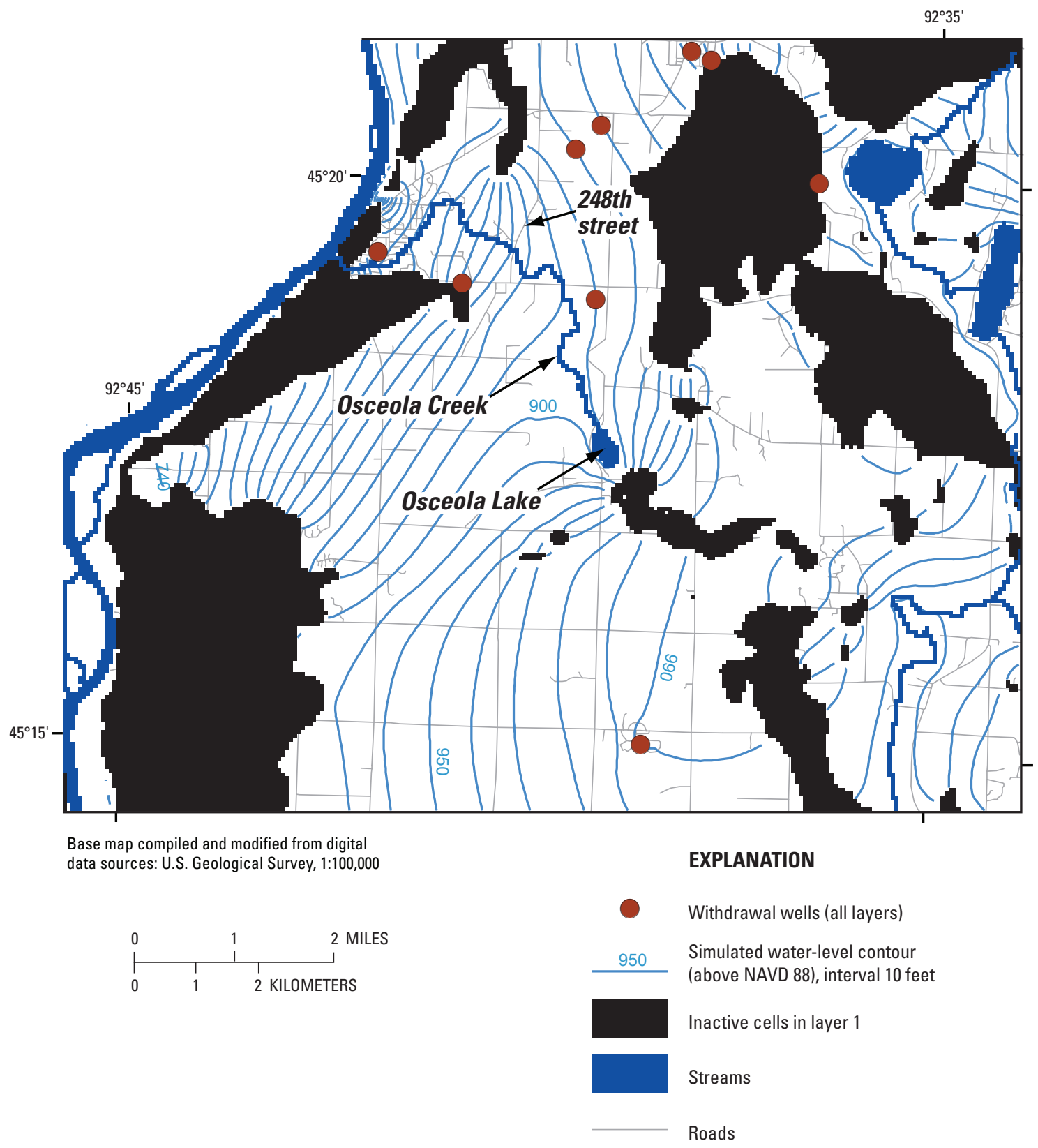

Figure 24. Simulated groundwater-flow patterns near Osceola Creek, Polk County, Wisconsin. 


\section{Model Limitations}

As is the case with all groundwater-flow models, the regional and demonstration inset models are simplifications of the physical system and have corresponding limitations in model precision and how the models can be used. For example, the MODFLOW model discretization (cells) for the regional model is $1,000 \mathrm{ft}$ by $1,000 \mathrm{ft}$. As a result of this discretization, the conditions within the cell (groundwater level, groundwater flow) are reduced to one average value for the entire cell. Therefore, analyses of local and site-specific problems would benefit from refinement of the regional model in situations for which additional detail is warranted. Hydrologic parameter values and aquifer and confining-unit geometry in parts of the model area are not well known at local scales. For example, aquifer thickness and hydraulic conductivity can change vertically at intervals smaller than the current model resolution, especially near valley bluffs or ridges of crystalline bedrock, such as in west-central Polk County. In addition, a modeling artifact (dry cells) affected simulated groundwater levels and flows in western and northern Polk County. Although simulation of the regional flow is representative, modeling local flow near the dry cells may require additional refinement to the model.

The model-calibration process focused on long-term water-level and base-flow targets to estimate areally averaged properties of regional aquifers and confining units in the three-county area. Local complexities, such as perched water tables and karst aquifers, were not explicitly simulated in the regional model. Moreover, although the model simulated the upper bedrock aquifer as one layer, the section actually contains several layered aquifers and confining units. Thus, if simulation of the distribution of groundwater flow among individual units in this upper bedrock aquifer is important for the modeling objective, layer 1 may need to be divided into additional hydrostratigraphic layers, as was done for the demonstration models. In addition, water-level and base-flow targets are insufficient to estimate groundwater velocities and age. Estimation of groundwater-flow velocities was not a focus of this study, and future applications of the models for such purposes would benefit from field analyses of porosity, groundwater age, and traveltimes. Also, little information is available on how the two regionally extensive faults influence regional and local groundwater flow. These faults were simulated with relatively simple changes in hydraulic conductivity in cells that are likely about 100 times wider than each fault. Where groundwater flow or water-level drawdown near these features is an important consideration, additional hydraulic information about the faults and more advanced methods of simulation may be required.

The regional model may not perform equally in all locations because of local geologic complexities that were not incorporated into the model. For example, the regional model has limited ability to delineate groundwater-contributing areas for headwater streams, which are sensitive to local geologic conditions that were not simulated in the regional model. This is illustrated in the headwater area of Big River in Pierce County, which is simulated as a losing reach in the regional model (fig. 16) but is simulated as a gaining reach in the Pierce County inset model (fig. 22), in which additional geologic layering was simulated. Also, the regional model may underestimate the groundwater-contributing areas (and associated base flows) for the Kinnickinnic and Rush Rivers because the simulated shallow groundwater divide in central St. Croix County (fig. 11A) is west of the divide mapped by Lippelt (1990b). Moreover, the karst nature of the Prairie du Chien Group further complicates interpretation of simulated results associated with local flow paths, traveltimes, and contaminant transport (Tipping and others, 2006; Cobb, 2007) in the upper bedrock aquifer.

Lastly, the three county inset models were designed for demonstration purposes. Although the model construction and parameter values were refined to improve the match to measured water levels and streamflows, the demonstration models were not rigorously tested. Therefore, results from these models are provided for illustration purposes only. Additional refinement, particularly in response to additional data collection, would be needed if simulated results from the demonstration models were to be used for informing management decisions.

\section{Suggestions for Future Investigations}

The regional and demonstration groundwater-flow models could be enhanced with additional hydrologic and geologic investigations, data collection and interpretation, and the use of additional MODFLOW options and packages. As new data become available, the models could be updated and recalibrated. The following is a list of investigative tasks, data-collection needs, and MODFLOW options that could increase the utility of the groundwater-flow models.

1. Within Pierce, Polk, and St. Croix Counties, there are only two currently operating observation wells (nonpumping wells) in which water levels are monitored. Three of the five long-term observation wells in the counties that were used to calibrate the regional model (table $3 \mathrm{~A}$ ) are no longer in operation. Moreover, the two operating observation wells monitor only the sand and gravel aquifer and do not provide information on the deeper flow system or flow between the shallow and deep systems. Monitoring of water levels, especially with nested wells in which two or more wells are open to only one hydrostratigraphic unit, would provide insight and valuable calibration points for future refinement of the model. Nested monitoring wells in the lower bedrock aquifers would aid in understanding flow across confining units, thereby improving understanding of how water levels in deep aquifers respond to well pumping and associated drawdown. 
2. The hydraulic relations between the St. Croix, Mississippi, and Chippewa Rivers and the groundwater system are not fully understood. Specifically, the extent of "windows" in the shale-rich Eau Claire Formation below the rivers is approximated in the regional model by interpolation of stratigraphic contacts in well logs and geologic mapping in adjacent Minnesota counties. Additional geologic and(or) geophysical mapping within the St. Croix, Mississippi, and Chippewa River Valleys could improve understanding of groundwater/surface-water interaction near these important regional water bodies and could improve understanding of groundwater-flow patterns and drawdown in the deep aquifers.

3. The hydraulic effects of faulting are not fully understood in the three counties. For example, in the present simulation, faults are assumed to enhance vertical permeability and diminish horizontal permeability relative to the hydrostratigraphic unit the fault intersects. Although hydraulic properties of the faults had only moderate sensitivity (fig. 15) for the regional model calibration, faults may have substantial influence on local flow patterns and drawdown. Local hydraulic studies of flow through areas with faulting (for example, by use of nested wells, pumping tests, tracers, or geologic core samples) would help to evaluate the degree to which faults influence local groundwater flow.

4. Flow through local karst aquifers, particularly in central St. Croix and Pierce Counties, is not well simulated in the regional model. Karst aquifers in this study have been lumped with porous sedimentary aquifers, and flow through karst aquifers has been approximated by use of porous-media assumptions. Work by Runkel and others (2003), LePain and others (2005), Tipping and others (2006), and Cobb (2007) provides a basis for advancing the understanding of local groundwater flow in karst aquifers in the counties, and these authors' publications include suggestions for better characterizing these poorly understood areas.

5. Springs in the river valleys are not simulated explicitly because of the regional nature of the model and the consolidation of the upper bedrock aquifer into one layer. Explicit simulation of springs could be added to the model in the future, but doing so may require additional geologic and hydrologic information. For example, Cobb (2007) identified an apparent relation between springs and their topographic position relative to the Prairie du Chien Group. An improved understanding of the spatial and temporal sources of water to springs could be gained by additional field investigation and modeling.

6. The distribution and rate of recharge, along with the potential to alter recharge rates, are not well understood in the three counties. Recharge is an important source of water to aquifers that supply base flow to streams (table 4). An understanding of recharge distribution would assist water-resource managers in evaluation of the effectiveness of mitigation practices designed to protect or enhance recharge in local areas. Tools now exist that are designed to estimate patterns and rates of recharge on the basis of physical processes and the properties and patterns of soils, rocks, precipitation, evaporation, and streamflows in an area (S.M. Westenbroek, U.S. Geological Survey, written commun., 2008).

7. To increase the utility of the regional model, several features could be added. Climatic variations, such as drought and significant recharge events, can be simulated if the model is run in transient mode, as demonstrated with the Polk County inset model. An optimization code, such as the MODFLOW module GWM (Ahlfeld and others, 2005), which helps select the optimum or "best" pumping schemes for a given objective (for example, maintaining surface-water flows while increasing groundwater withdrawal), could be coupled to the groundwater-flow model to enhance the model as a tool to guide location of future wells and developments. An optimization model could be used to choose well locations so that future pumping would have a minimal adverse effect on streamflow and wetlands but still meet increased water needs associated with population growth in the three counties.

8. The three inset models were constructed for demonstration purposes only. However, these models could be enhanced to address specific questions through the collection or compilation of additional hydrologic data and by calibration of the models to address the stated purpose. Simulation of groundwater flow through karst aquifers in the St. Croix County model would most likely be improved with data from investigations described in item 4 above. Simulation of groundwater/lake-water interaction near Twin Lakes would be improved with data from a focused field investigation of local hydraulic gradients and water-budget components for the lake. Delineation of groundwater-contributing areas in Pierce County could be improved with measurements of base flow along Big River and from evaluations of how uncertainty in model parameters and unsimulated seasonal variability could influence the distribution of groundwater divides. Evaluations of development near Osceola and the potential effects on base flow in Osceola Creek would likely require long-term measurements of base flow in the creek. Use of the previously described rechargeestimation and groundwater-optimization tools could also improve understanding of the system and aid in land-use planning decisions. 


\section{Summary and Conclusions}

A regional three-dimensional groundwater-flow model and three associated demonstration inset models were developed to simulate the groundwater-flow systems in Pierce, Polk, and St. Croix Counties, WI. The models were developed by the USGS in cooperation with the three county governments. Although all four models were designed to provide information about the groundwater-flow system, results from the three county inset models are presented for demonstration purposes only and are not sufficiently detailed or calibrated to be used for decisionmaking purposes. The objectives of the regional model of Pierce, Polk, and St. Croix Counties were to improve understanding of the groundwater-flow system and to develop a tool suitable for evaluating the effects of potential water-management programs. Simulations made with the regional model reproduce groundwater levels and stream base flows representative of recent (1994-2004) conditions and illustrate groundwater-flow patterns with simulated water-table and potentiometric-surface maps. In addition, the regional model was designed as a framework from which more detailed inset models could be extracted, as was demonstrated by incorporating additional capabilities into the inset model for each county.

Four aquifers were simulated in the regional model, represented by (1) a shallow unconsolidated sand and gravel aquifer; (2) an upper bedrock aquifer, composed of Cambrian and Ordovician sandstone and dolomite; (3) an intermediate bedrock aquifer, composed of Cambrian sandstone of the Wonewoc Formation; and (4) a lower bedrock aquifer, composed of Cambrian sandstone of the Mount Simon Formation. A shale layer that is part of the Eau Claire Formation was simulated as a confining unit separating the Wonewoc and Mount Simon aquifers. Additional confining units within the upper bedrock aquifer were not explicitly simulated in the regional model. Precambrian crystalline basement rock forms the lower base of the groundwater-flow system.

The USGS MODFLOW groundwater-flow model code was used to develop the regional and demonstration inset groundwater-flow models. Boundary conditions for the regional MODFLOW model were extracted from a USGSdeveloped analytic-element screening model of regional groundwater flow in the St. Croix River Basin and adjacent basins. Model input was obtained from previously published and unpublished geologic and hydrologic data. Pumping rates from municipal and non-municipal high-capacity wells also were simulated.

Model calibration included a comparison between modeled and field-measured water levels and modeled and field-measured base flows in simulated rivers. After calibration, most measured water levels compared favorably to model-calculated water levels; the mean absolute difference and root mean squared difference between measured and simulated water levels were less than 6 percent of the total range in measured water levels. Simulated base flows were within 10 percent of estimated base flows at 8 of 10 streamflow-gaging stations where year-round streamflow records were available. As currently calibrated, the model is suitable for use as a regional water-management tool. Because of the regional focus, however, the model may need to be refined for local-scale simulations.

Mass-balance results from the regional model indicated that about 82 percent of groundwater in the three counties was from recharge within the counties; 15 percent was from surface-water sources, consisting primarily of recirculated groundwater seepage in areas with abrupt surface-waterlevel changes, such as near waterfalls, dams, and along the downgradient side of reservoirs and lakes; and 4 percent was from inflow across the county boundaries. Groundwater flow out of the counties was to streams ( 85 percent), outflow across county boundaries (14 percent), and pumping wells (1 percent). These results demonstrate that the primary source of groundwater withdrawn by pumping wells is water that recharged within the counties and would have otherwise discharged to local streams and lakes.

Simulated water levels and particle tracking in the regional model illustrate groundwater-flow paths through the layered aquifer system from recharge areas toward groundwater discharge areas, such as rivers and wells. Groundwater discharge to lakes and large rivers (St. Croix and Mississippi) is greatest along their shoreline and decreases away from shore. Under current conditions, the St. Croix and Mississippi Rivers are groundwater discharge locations (gaining reaches) and appear to function as "fully penetrating" hydraulic boundaries such that groundwater does not cross between Wisconsin and Minnesota beneath them. Being hydraulic boundaries, however, they can change in response to water withdrawals. The tributary rivers contain both gaining and losing reaches, especially near dams and reservoirs. Tributary rivers act as "partially penetrating" hydraulic boundaries such that groundwater can flow underneath them. In the conceptualization used here, faults have relatively modest influence on regional horizontal and vertical flow patterns in all layers, except where the Mount Simon aquifer is adjacent to crystalline bedrock and hydraulic damming occurs. However, this conceptualization is not definitive, and additional study of faults would improve the understanding of groundwater flow near them. The model also demonstrates the effects of development on groundwater in the study area. Water-level declines since predevelopment (no withdrawal wells) are most pronounced where pumping is greatest and flow between layered aquifers is impeded by confining units or faults. The maximum simulated water-level decline was about $40 \mathrm{ft}$ in the deep Mount Simon aquifer below the city of Hudson, WI.

Three inset models were extracted from the regional model to demonstrate the process and additional capabilities of the USGS MODFLOW code. Results from these simulations were for demonstration purposes only and would need to be reevaluated through the addition of data and associated refinements to the models prior to use of any inset-model results to support management decisions. Simulation of groundwater/ 
lake-water interaction near Twin Lakes near Roberts, in St. Croix County, WI, showed that groundwater represents approximately 5 to 20 percent of the overall lake-water budget. Groundwater contributing areas to streams in western Pierce County generally are similar in size to the surfacewater-contributing areas but do not necessarily correspond to the same land area. Transient streamflow simulations of Osceola Creek in Polk County demonstrate how stream base flow can be influenced not only by seasonal precipitation and recharge variability but also by systematic changes to the system, such as groundwater withdrawal from wells.

For most efficient use, the regional model would require periodic updates and improvements as additional field data, better assessments of complex hydrologic features (for example, faults and karst aquifers), and estimates of future hydrologic stressors become available. Additional data collection could improve model characterization of the aquifers, springs, lakes, and recharge distribution and magnitude. Transient calibration and the use of advanced "packages" of the MODFLOW code (for example, the GWM pumping well optimization code; Ahlfeld and others, 2005) could improve the calibration and utility of the model as a water-resources management tool.

\section{Acknowledgments}

Thanks are expressed to David Fodroczi, St. Croix County, for arranging multiple meetings at which groundwater-flow concepts and project results were discussed with the cooperating agencies and the interested public. Kenneth Bradbury, Wisconsin Geological and Natural History Survey, provided valuable feedback on the report, as well as on model parameters for the regional and inset models. Ray Wuolo, Barr Engineering, is thanked for reviewing the report and providing advice and information on groundwater flow in Washington County, MN. James Boettcher, Wisconsin Department of Natural Resources, supplied water-level data used to calibrate the model. Maureen Muldoon, University of WisconsinOshkosh, and Peter Schoephoester, Wisconsin Geological and Natural History Survey, provided well-construction report data that were originally used to produce the Pierce, Polk, and St. Croix County water-table maps that are now incorporated into the regional model as water-level targets. David LePain, formerly with the Wisconsin Geologic and Natural History Survey, organized a geologic field trip to the study area and provided valuable insight into the geologic properties of Pierce and St. Croix Counties. Randall Hunt, Charles Dunning, and Daniel Feinstein, all of the USGS Wisconsin Water Science Center, provided valuable feedback on model design, construction, and calibration throughout the project. Cheryl Buchwald, USGS Wisconsin Water Science Center, compiled water-use information for high-capacity wells in the model area. Keith Solimar, Town of Warren, Groundwater Citizens Advisory Committee, provided lake-stage data for
Twin Lakes that were used in the demonstration model for St. Croix County. Kenneth Schreiber, Wisconsin Department of Natural Resources, provided data from a hydrologic study of Twin Lakes. Michael Cobb, formerly with the University of Wisconsin, Geology and Geophysics Department, provided a georeferenced grid of the estimated contact elevation between the Prairie du Chien Group and Jordan Formation that was used in constructing the St. Croix and Pierce County demonstration models.

\section{References}

Ahlfeld, D.P., Barlow, P.M., and Mulligan, A.E., 2005 GWM-A ground water management process for the U.S. Geological Survey modular ground-water model (MODFLOW-2000): U.S. Geological Survey Open-File Report 2005-1072, 124 p.

Anderson, M.P., and Woessner, W.W., 1992, Applied groundwater modeling: San Diego, Calif., Academic Press, 381 p.

Baker, R.W., 1984, Pleistocene history of west-central Wisconsin: Wisconsin Geological and Natural History Survey Field Trip Guide Book 11, 76 p.

Barr Engineering Company and Washington County [Minnesota], 2005, Intercommunity groundwater protection-Sustaining growth and natural resources in the Woodbury/Afton Area: Report on development of a groundwater flow model of southern Washington County, Minnesota, 67 p.

Borman, R.G., 1976, Ground-water resources and geology of St. Croix County, Wisconsin: Wisconsin Geological and Natural History Survey Information Circular 32, 30 p.

Brown, B.A., 1988, Bedrock geology of Wisconsin, regional map series - West-central sheet: Wisconsin Geological and Natural History Survey Map 88-7, scale 1:250,000.

Cannon, W.F., Kress, T.H., Sutphin, D.M., Morey, G.B., Meints, Joyce, and Barber-Delach, Robert, 1997, Digital geologic map and mineral deposits of the Lake Superior Region, Minnesota, Wisconsin, Michigan: U.S. Geological Survey Open-File Report 97-455, scale 1:1,000,000, additional GIS data added in 1999, accessed March 24, 2006, at http://pubs.usgs.gov/of/1997/of97-455/

Caine, J.S., Evans, J.P., and Forster, C.B., 1996, Fault zone architecture and permeability structure: Geology, v. 24, no. 11, p. 1025-1028.

Cobb, M.K., 2007, Hydrogeologic characterization of the Ordovician Prairie du Chien Group in west-central Wisconsin: University of Wisconsin-Madison, Department of Geology and Geophysics, M.S. thesis, 170 p. 
Delin, G.N., and Woodward, D.G., 1984, Hydrogeologic setting and potentiometric surfaces of regional aquifers in the Hollandale Embayment, southeastern Minnesota, 19701980: U.S. Geological Survey Water-Supply Paper 2219, $56 \mathrm{p}$.

Doherty, J., 2004, PEST-Model-independent parameter estimation user manual (5th ed.): Brisbane, Queensland, Australia, Watermark Numerical Computing.

Evans, T.J., Cordua, W.S., and LePain, D.L., 2007, Preliminary geology of the buried bedrock surface, Pierce County, Wisconsin: Wisconsin Geological and Natural History Survey Open-File Report 2007-08, 1 sheet, scale 1:100,000.

Feinstein, D.T., Buchwald C.A., Dunning C.P., and Hunt R.J., 2006, Development and application of a screening model for simulating regional ground-water flow in the St. Croix River Basin, Minnesota and Wisconsin: U.S. Geological Survey Scientific Investigations Report 2005-5283, 41 p.

Feinstein, D., Eaton, T., Hart, D., Krohelski, J., and Bradbury, K.R., 2005, Regional aquifer model for southeastern Wisconsin; Report 1-Data collection, conceptual model development, numerical model construction, and model calibration: Southeastern Wisconsin Regional Planning Commission Technical Report 41, 81 p.

Gebert, W.A., Radloff, M.J., Considine, E.J., and Kennedy, J.L., 2007, Use of streamflow data to estimate base flow/ ground-water recharge for Wisconsin: Journal of the American Water Resources Association, v. 43, no. 1, p. 220-236.

Haitjema, H.M., 1995, Analytic element modeling of groundwater flow: San Diego, Calif., Academic Press, 394 p.

Haitjema, Henk, 2006, The role of hand calculations in ground water flow modeling: Ground Water, v. 44, no. 6, p. 786-791.

Harbaugh, A.W., Banta, E.R., Hill, M.C., and McDonald, M.G., 2000, MODFLOW-2000, The U.S. Geological Survey modular ground-water model-User guide to modularization concepts and the ground-water flow process: U.S. Geological Survey Open-File Report 00-92, 121 p.

Hart, D.J., Bradbury, K.R., Feinstein, D.T., and Tikoff, B., 2006, Mechanisms of groundwater flow across the Maquoketa Formation: Final Report submitted to the Wisconsin Department of Natural Resources Groundwater Monitoring and Research Program at completion of grant number 144-NP30, 47 p.

Hsieh, P.A., and Freckleton, J.R., 1993, Documentation of a computer program to simulate horizontal-flow barriers using the U.S. Geological Survey's modular three-dimensional finite-difference ground-water flow model: U.S. Geological Survey Open-File Report 92-477, 32 p.
Hunt, R.J., Anderson, M.P., and Kelson, V.A., 1998, Improving a complex finite-difference ground water flow model through the use of an analytic element screening model: Ground Water, v. 36, no. 6, p.1011-1017.

Hunt, R.J., Doherty, John, and Tonkin, M.J., 2007, Are models too simple? Arguments for increased parameterization: Ground Water, v. 45, no. 3, p. 254-262; doi:10.1111/j. 1745-6584.2007.00316.x.

Hunt, R.J., Kelson, V.A., and Anderson, M.P., 1998, Linking an analytic element flow code to MODFLOW-Implementation and benefits, in MODFLOW'98-Proceedings of the Third International Conference of the International Ground Water Modeling Center, Golden, Colo., Colorado School of Mines: p. 497-504.

Hunt, R.J., and Krohelski, J.T., 1996, The application of an analytic element model to investigate groundwater-lake interactions at Pretty Lake, Wisconsin: Lake and Reservoir Management, v. 12, no. 4, p. 487-495.

Hunt, R.J., Saad, D.A., and Chapel, D.M., 2003, Numerical simulation of ground-water flow in La Crosse County, Wisconsin, and into nearby pools of the Mississippi River: U.S. Geological Survey Water-Resources Investigations Report 03-4154, 35 p.

Johnson, A.I., 1967, Specific yield-Compilation of specific yields for various materials: U.S. Geological Survey WaterSupply Paper 1662-D, 74 p.

Johnson, M.D., 2000, Pleistocene geology of Polk County, Wisconsin: Wisconsin Geological and Natural History Survey Bulletin 92, 70 p.

Juckem, P.F., 2003, Spatial patterns and temporal trends in groundwater recharge, upper Coon Creek Watershed, southwest Wisconsin: University of Wisconsin-Madison, Department of Geology and Geophysics, M.S. thesis, 264 p.

Juckem, P.F., 2007, Hydrogeologic characteristics of the St. Croix River Basin, Minnesota and WisconsinImplications for the susceptibility of ground water to potential contamination: U.S. Geological Survey Scientific Investigations Report 2007-5112, 25 p.

Juckem, P.F., and Hunt, R.J., 2007, Simulation of the shallow ground-water-flow system near Grindstone Creek and the community of New Post, Sawyer County, Wisconsin: U.S. Geological Survey Scientific Investigations Report 2007-5014, 29 p.

Juckem, P.F., Hunt, R.J., and Anderson, M.P., 2006, Scale effects of hydrostratigraphy and recharge zonation on base flow: Ground Water, v. 44, no. 3, p. 362-370.

Kammerer, P.A., Trotta, L.C., Krabbenhoft, D.P., and Lidwin, R.A., 1998, Geology, ground-water flow, and dissolvedsolids concentrations in ground water along hydrogeologic sections through Wisconsin aquifers: U.S. Geological Survey Hydrologic Investigations Atlas HA-731, 4 sheets. 
Kanivetsky, R., and Hoyer, M.C., 1987, Hydraulic parameters at an experimental aquifer thermal energy storage facility, St. Paul, Minnesota [abs.]: North-Central Section, Geological Society of America Annual Meeting, 21st, St. Paul, Minnesota, 1987: Abstracts with Programs, v. 19, no. 4, p. 207.

Kanivetsky, R., and Walton, M., 1979, Hydrogeologic map of Minnesota, bedrock hydrogeology-A discussion to accompany State Map Series S-2: Minnesota Geological Survey, $11 \mathrm{p}$.

Kostka, S.J., Hinke, H.J., Mickelson, D.M., and Baker, R.W., 2004, Preliminary Quaternary geologic map of St. Croix County, Wisconsin: Wisconsin Geological and Natural History Survey Open-File Report 2004-22, 1 sheet, scale 1:100,000.

Krohelski, J.T., Bradbury, K.R., Hunt, R.J., and Swanson, S.K., 2000, Numerical simulation of ground-water flow in Dane County, Wisconsin: Wisconsin Geological and Natural History Survey Bulletin 98, 31 p.

LePain, D.L., 2006, Preliminary geologic map of the buried bedrock surface of St. Croix County, Wisconsin: Wisconsin Geological and Natural History Survey Open-File Report 2006-04, 1 sheet, scale 1:100,000.

LePain, D.L., Bradbury, K.R., and Cobb, M.K., 2005, Hydrostratigraphy of west-central Wisconsin-A new approach to groundwater management: Wisconsin Geological and Natural History Survey, available online at http://wri.wisc. edu/Downloads/Projects/Final_WR04R006.pdf

Lippelt, I.D., 1990a, Generalized water-table elevation map of Pierce County, Wisconsin: Wisconsin Geological and Natural History Survey Miscellaneous Map 31, scale 1:100,000.

Lippelt, I.D., 1990b, Generalized water-table elevation map of St. Croix County, Wisconsin: Wisconsin Geological and Natural History Survey Miscellaneous Map 32, scale 1:100,000.

Lorenz, D.L., and Delin, G.N., 2007, A regression model to estimate regional ground-water recharge in Minnesota: Ground Water, v. 45, no. 2, p. 196-208.

Mandle, R.J., and Kontis, A.L., 1992, Simulation of regional ground-water flow in the Cambrian-Ordovician aquifer system in the Northern Midwest, United States: U.S. Geological Survey Professional Paper 1405-C, 97 p.

Martin, Lawrence, 1965, The physical geography of Wisconsin (3d ed.): Madison, WI, University of Wisconsin Press, 608 p.

Masarik, K., Janke, J., and Mechenich, D., 2006, An introduction to groundwater in St. Croix County: University of Wisconsin-Extension, Center for Watershed Science and Education/UW-Stevens Point, 37 p.
McDonald, M.G., and Harbaugh, A.W., 1988, A modular threedimensional finite-difference ground-water flow model: U.S. Geological Survey Techniques of Water-Resources Investigations, book 6, chap. A1, 586 p.

Mehl, S.W., and Hill, M.C., 2005, MODFLOW-2005, the U.S. Geological Survey modular ground-water modelDocumentation of shared node local grid refinement (LGR) and the Boundary Flow and Head (BFH) Package: U.S. Geological Survey Techniques and Methods 6-A12, 68 p.

Mehl, S.W., and Hill, M.C., 2007, MODFLOW-2005, the U.S. Geological Survey modular ground-water modelDocumentation of the multiple-refined-areas capability of local grid refinement (LGR) and the Boundary Flow and Head (BFH) Package: U.S. Geological Survey Techniques and Methods 6-A21, $13 \mathrm{p}$.

Merritt, M.L., and Konikow, L.F., 2000, Documentation of a computer program to simulate lake-aquifer interaction using the MODFLOW ground-water flow model and the MOC3D solute-transport model: U.S. Geological Survey WaterResources Investigations Report 00-4167, 146 p.

Mickelson, D.M., Clayton, L., Baker, R.W., Mode, W.N., and Schneider, A.F., 1984, Pleistocene stratigraphic units of Wisconsin: Wisconsin Geological and Natural History Survey Miscellaneous Paper 84-1, 15 p. plus appendixes.

Miller, R.T., 1984, Anisotropy in the Ironton and Galesville Sandstones near a thermal-energy-storage well, St. Paul, Minnesota: Ground Water, v. 22, no. 5, p. 532-537.

Miller, R.T., and Delin, G.N., 1993, Field observations, preliminary model analysis, and aquifer thermal efficiency: U.S. Geological Survey Professional Paper 1530-A, 55 p.

Mossler, J.H., 1983, Paleozoic lithostratigraphy of southeastern Minnesota: Minnesota Geological Survey Miscellaneous Map Series Map M-51., scale 1:500,000, 2 sheets.

Mossler, J.H., 1992, Sedimentary rocks of Dresbachian age (late Cambrian), Hollandale Embayment, southeastern Minnesota: Minnesota Geological Survey Report of Investigations $40,71 \mathrm{p}$.

Mudrey, M.G., Jr., LaBerge, G.A., Myers, P.E., and Cordua, W.S., 1987, Bedrock geology of Wisconsin-Northwest sheet: Wisconsin Geological and Natural History Survey Regional Map Series, Map 87-11, 2 sheets, scale 1:250,000.

Muldoon, M.A., 2000, Generalized water-table elevation map of Polk County, Wisconsin: Wisconsin Geological and Natural History Survey Miscellaneous Map 48, scale 1:100,000.

Muldoon, M., Keen, K., and Rader, C., 2007, Regional hydrogeologic study of Pierce and St. Croix Counties, Wisconsin-Delineation of zones of contribution for municipal wells in Pierce and St. Croix Counties, Wisconsin: Report submitted to the Source Water Assessment Program, Wisconsin Department of Natural Resources, $52 \mathrm{p}$. 
Natural Resources Conservation Service, 2002, WETS tables, accessed April 28, 2009, at http:// www.wcc.nrcs.usda.gov/ climate/clim-data.html

Niswonger, R.G., and Prudic, D.E., 2005, Documentation of the streamflow-routing (SFR2) package to include unsaturated flow beneath streams-A modification to SFR1: U.S. Geological Survey Techniques and Methods 6-A13, $47 \mathrm{p}$.

Ostrom, M.E., 1967, Paleozoic stratigraphic nomenclature for Wisconsin: Wisconsin Geologic and Natural History Survey Information Circular 8, 1 sheet.

Pollock, D.W., 1994, User's guide for MODPATH/ MODPATH-PLOT, version 3-A particle tracking postprocessing package for MODFLOW, the U.S. Geological Survey finite-difference ground-water flow model: U.S. Geological Survey Open-File Report 94-464, 248 p.

Prudic, D.E., 1989, Documentation of a computer program to simulate stream-aquifer relations using a modular, finitedifference, ground-water flow model: U.S. Geological Survey Open-File Report 88-0729, 113 p.

Rawling, G.C., Goodwin, L.B., and Wilson, J.L., 2001, Internal architecture, permeability structure, and hydrologic significance of contrasting fault-zone types: Geology, v. 29, no. 1, p. $43-46$.

Ruhl, J.F., Kanivetsky, Roman, and Shmagin, Boris, 2002, Estimates of recharge to unconfined aquifers and leakage to confined aquifers in the seven-county metropolitan area of Minneapolis-St. Paul, Minnesota: U.S. Geological Survey Water-Resources Investigations Report 02-4092, 32 p.

Rumbaugh, J.O., and Rumbaugh, D.B., 2007, Groundwater Vistas, version 5: Herndon, Va., Environmental Simulations Inc., $372 \mathrm{p}$.

Runkel, A.C., Tipping, R.G., Alexander, E.C., Jr., and Alexander, S.C., 2006, Hydrostratigraphic characterization of intergranular and secondary porosity in part of the Cambrian sandstone aquifer system of the cratonic interior of North America-Improving predictability of hydrogeologic properties: Sedimentary Geology, v. 184, p. 281-304.

Runkel, A.C., Tipping, R.G., Alexander, E.C., Jr., Green, J.A., Mossler, J.H., and Alexander, S.C., 2003, Hydrogeology of the Paleozoic bedrock in southeastern Minnesota: Minnesota Geological Survey Report of Investigations 61, 105 p., 2 pls.

Scanlon, B.R., Healy, R.W., and Cook, P.G., 2002, Choosing appropriate techniques for quantifying groundwater recharge: Hydrogeology Journal, v. 10, no. 1, p. 18-39.

Schoenberg, M.E., 1984, Water levels and water-level changes in the Prairie du Chien-Jordan and Mount Simon-Hinckley aquifers, Twin Cities Metropolitan Area, Minnesota, 1971-80: U.S. Geological Survey Water-Resources Investigations Report 83-4237, 23 p., 2 pls.
Schoenberg, M.E., 1990, Effects of present and projected ground-water withdrawals on the Twin Cities aquifer system, Minnesota: U.S. Geological Survey WaterResources Investigations Report 90-4001, 165 p.

Schreiber, K., 1995, Twin Lakes/Roberts WWTP water quality assessment: Wisconsin Department of Natural Resources, $26 \mathrm{p}$.

Steuer, J.J., and Hunt, R.J., 2001, Use of a watershed-modeling approach to assess hydrologic effects of urbanization, North Fork Pheasant Branch basin near Middleton, Wisconsin: U.S. Geological Survey Water-Resources Investigations Report 01-4113, 49 p.

Strack, O.D.L., 1989, Groundwater mechanics: Englewood Cliffs, N.J., Prentice-Hall, 732 p.

Strack, O.D.L., Fitts, C.R., and Zaadnoordijk, W.J., 1987, Application and demonstration of analytic element models, in Proceedings, Solving Groundwater Problems with Models, Denver, Colo.: p. 1464-1474.

Tipping, R.G., Runkel, A.C., Alexander, E.C., Jr., Alexander, S.C., and Green, J.A., 2006, Evidence for hydraulic heterogeneity and anisotropy in the mostly carbonate Prairie du Chien Group, southeastern Minnesota, USA: Sedimentary Geology, v. 184, p. 305-330.

Trotta, L.C., and Cotter, R.D., 1973, Depth to bedrock in Wisconsin: Wisconsin Geological and Natural History Survey Map, 1 sheet, 1:1000,000.

Wahl, K.L., and Wahl, T.L., 1995, Determining the flow of Comal Springs at New Braunfels, Texas, in Proceedings, Texas Water '95, American Society of Civil Engineers, August 16-17, 1995, San Antonio, Tex., p. 77-86.

Ward, D.S., Buss, D.R., Mercer, J.W., and Hughes, S.S., 1987, Evaluation of a groundwater corrective action at the ChemDyne hazardous waste site using a telescopic mesh refinement modeling approach: Water Resources Research, v. 23, no. 4, p. 603-617.

Wisconsin Department of Natural Resources, 1998, Wisconsin Land Cover Image-Level 2, accessed April 28, 2009, at http://www.dnr.state.wi.us/maps/gis/datalandcover.html

Wisconsin Department of Natural Resources, 2003, Water well data files, CD-ROM.

Wisconsin Geological and Natural History Survey, 2003, Wisc LITH - A digital lithologic and stratigraphic database of Wisconsin geology, version 2: CD-ROM.

Witherspoon, P.A., and Neuman, S.P., 1967, Evaluating a slightly permeable caprock in aquifer gas storage-I. Caprock of infinite thickness: Journal of Petroleum Technology, p. 949-955.

Young, H.L., 1992, Hydrogeology of the Cambrian-Ordovician aquifer system in the Northern Midwest, United States: U.S. Geological Survey Professional Paper 1405-B, 99 p. 
Appendix 1. Groundwater withdrawals from municipal wells in the regional groundwater-flow model.

[DNR, Wisconsin Department of Natural Resources]

\begin{tabular}{|c|c|c|c|c|c|c|c|}
\hline \multicolumn{3}{|c|}{ Location in model } & \multicolumn{2}{|c|}{$\begin{array}{c}\text { Average pumping rate, } \\
1994-2004\end{array}$} & \multirow{2}{*}{$\begin{array}{l}\text { Wisconsin } \\
\text { unique } \\
\text { well number }\end{array}$} & \multirow{2}{*}{$\begin{array}{l}\text { DNR } \\
\text { permit } \\
\text { number }\end{array}$} & \multirow[b]{2}{*}{ County } \\
\hline Layer & Row & Column & $\begin{array}{l}\text { Million } \\
\text { gallons } \\
\text { per year }\end{array}$ & $\begin{array}{l}\text { Million } \\
\text { gallons } \\
\text { per day }\end{array}$ & & & \\
\hline 1 & 500 & 184 & 18.2 & 0.050 & HW379 & 01742 & Pierce \\
\hline 1 & 436 & 99 & 30.8 & .080 & EP394 & 02336 & Pierce \\
\hline $1,2,3$ & 438 & 96 & 41.9 & .11 & BG679 & 84046 & Pierce \\
\hline 1 & 436 & 95 & 85.4 & .23 & BG680 & 84047 & Pierce \\
\hline $1,2,3$ & 448 & 176 & 41.4 & .11 & AY376 & 84041 & Pierce \\
\hline 1 & 448 & 178 & 59.1 & .16 & BG675 & 84042 & Pierce \\
\hline 3,4 & 430 & 265 & 9.03 & .025 & KQ651 & 01743 & Pierce \\
\hline $1,2,3,4$ & 435 & 263 & 10.8 & .029 & BG676 & 84043 & Pierce \\
\hline 1 & 432 & 263 & 9.27 & .025 & BG677 & 84044 & Pierce \\
\hline 1 & 402 & 141 & 83.0 & .23 & BG681 & 84048 & Pierce \\
\hline 1 & 399 & 140 & 87.2 & .24 & BG682 & 84049 & Pierce \\
\hline 1 & 404 & 140 & 123 & .34 & BG683 & 84050 & Pierce \\
\hline 1 & 399 & 136 & 124 & .34 & BG684 & 84051 & Pierce \\
\hline $1,2,3$ & 409 & 242 & 39.8 & .11 & BG686 & 84053 & Pierce \\
\hline $2,3,4$ & 512 & 220 & 3.52 & .010 & BG678 & 84045 & Pierce \\
\hline 1 & 257 & 141 & 2.54 & .007 & BG395 & 82516 & Polk \\
\hline $1,2,3$ & 237 & 214 & 12.3 & .034 & BG371 & 82442 & Polk \\
\hline $1,2,3$ & 239 & 216 & 102 & .28 & BG372 & 82443 & Polk \\
\hline 1 & 186 & 189 & 11.6 & .032 & DV389 & 00879 & Polk \\
\hline 1 & 186 & 191 & 11.3 & .031 & BG373 & 82444 & Polk \\
\hline 1 & 186 & 191 & 14.7 & .040 & BG374 & 82445 & Polk \\
\hline 4 & 184 & 166 & 4.10 & .011 & BG376 & 82447 & Polk \\
\hline 4 & 184 & 166 & 27.0 & .074 & BG402 & 82523 & Polk \\
\hline $1,2,3$ & 232 & 260 & 13.7 & .038 & $\mathrm{CO} 065$ & 00716 & Polk \\
\hline 1 & 234 & 263 & 15.9 & .044 & BG378 & 82449 & Polk \\
\hline 1 & 260 & 237 & 187 & .51 & BG379 & 82500 & Polk \\
\hline 1 & 259 & 237 & 113 & .31 & BG381 & 82502 & Polk \\
\hline 1,2 & 220 & 144 & 20.9 & .057 & BG383 & 82504 & Polk \\
\hline $1,2,3,4$ & 221 & 145 & 29.2 & .080 & BG384 & 82505 & Polk \\
\hline 1 & 110 & 191 & 13.4 & .037 & BG385 & 82506 & Polk \\
\hline 1 & 108 & 189 & 10.3 & .028 & BG386 & 82507 & Polk \\
\hline 1 & 109 & 190 & 21.9 & .060 & BG387 & 82508 & Polk \\
\hline 1 & 109 & 190 & 23.9 & .066 & BG388 & 82509 & Polk \\
\hline 1 & 140 & 185 & 35.9 & .098 & BG389 & 82510 & Polk \\
\hline 1 & 139 & 185 & 7.28 & .020 & BG390 & 82511 & Polk \\
\hline 4 & 231 & 127 & 4.97 & .014 & BG394 & 82515 & Polk \\
\hline 2,3 & 232 & 132 & 98.2 & .27 & BG401 & 82522 & Polk \\
\hline 4 & 200 & 144 & 46.1 & .13 & CG779 & 01775 & Polk \\
\hline 4 & 196 & 146 & 16.8 & .046 & BG398 & 82519 & Polk \\
\hline
\end{tabular}


Appendix 1. Groundwater withdrawals from municipal wells in the regional groundwater-flow model.-Continued

[DNR, Wisconsin Department of Natural Resources]

\begin{tabular}{|c|c|c|c|c|c|c|c|}
\hline \multicolumn{3}{|c|}{ Location in model } & \multicolumn{2}{|c|}{$\begin{array}{c}\text { Average pumping rate, } \\
1994-2004\end{array}$} & \multirow{2}{*}{$\begin{array}{l}\text { Wisconsin } \\
\text { unique } \\
\text { well number }\end{array}$} & \multirow{2}{*}{$\begin{array}{l}\text { DNR } \\
\text { permit } \\
\text { number }\end{array}$} & \multirow[b]{2}{*}{ County } \\
\hline Layer & Row & Column & $\begin{array}{l}\text { Million } \\
\text { gallons } \\
\text { per year }\end{array}$ & $\begin{array}{l}\text { Million } \\
\text { gallons } \\
\text { per day }\end{array}$ & & & \\
\hline 4 & 201 & 147 & 16.1 & 0.044 & BG399 & 82520 & Polk \\
\hline 4 & 196 & 145 & 18.5 & .051 & BG400 & 82521 & Polk \\
\hline 1 & 158 & 179 & 30.5 & .084 & AV681 & 00590 & Polk \\
\hline 1 & 362 & 206 & 51.5 & .14 & BG846 & 85671 & St. Croix \\
\hline 1 & 367 & 208 & 51.1 & .14 & BG847 & 85672 & St. Croix \\
\hline 1 & 331 & 263 & 35.1 & .098 & BG870 & 85696 & St. Croix \\
\hline 1 & 358 & 191 & 12.2 & .033 & BG850 & 85676 & St. Croix \\
\hline 1 & 360 & 191 & 26.5 & .073 & BG851 & 85677 & St. Croix \\
\hline 1 & 366 & 119 & 27.7 & .076 & NV213 & 2915 & St. Croix \\
\hline 1 & 366 & 119 & 35.5 & .097 & RY274 & 2916 & St. Croix \\
\hline 4 & 360 & 112 & 115 & .32 & BG853 & 85679 & St. Croix \\
\hline $2,3,4$ & 357 & 110 & 117 & .32 & BG854 & 85680 & St. Croix \\
\hline $2,3,4$ & 348 & 110 & 56.9 & .16 & BG855 & 85681 & St. Croix \\
\hline 3,4 & 364 & 113 & 196 & .54 & BG856 & 85682 & St. Croix \\
\hline 4 & 346 & 108 & 31.3 & .086 & CG778 & 85697 & St. Croix \\
\hline $1,2,3,4$ & 305 & 167 & 11.04 & .030 & BG857 & 85683 & St. Croix \\
\hline $1,2,3,4$ & 303 & 166 & 88.9 & .24 & BG858 & 85684 & St. Croix \\
\hline 1 & 306 & 164 & 84.9 & .23 & BG859 & 85685 & St. Croix \\
\hline 1 & 309 & 169 & 197 & .54 & BG869 & 85695 & St. Croix \\
\hline 1 & 278 & 170 & 28.1 & .077 & BG864 & 85690 & St. Croix \\
\hline 1 & 354 & 161 & 22.7 & .062 & BG860 & 85686 & St. Croix \\
\hline 1 & 355 & 162 & 7.01 & .019 & BG861 & 85687 & St. Croix \\
\hline 1 & 304 & 130 & 30.3 & .083 & BG863 & 85689 & St. Croix \\
\hline $1,2,3,4$ & 300 & 133 & 37.8 & .10 & ET539 & 85694 & St. Croix \\
\hline 1 & 369 & 259 & 4.90 & .013 & BG865 & 85961 & St. Croix \\
\hline 1 & 370 & 230 & 31.6 & .087 & BG867 & 85963 & St. Croix \\
\hline
\end{tabular}


Appendix 2. Groundwater withdrawals from agricultural, commercial, and industrial wells in the regional groundwaterflow model.

[DNR, Wisconsin Department of Natural Resources]

\begin{tabular}{|c|c|c|c|c|c|c|c|c|}
\hline \multicolumn{3}{|c|}{ Location in model } & \multicolumn{2}{|c|}{$\begin{array}{c}\text { Estimated average } \\
\text { pumping rate, 1978-89 }\end{array}$} & \multirow{2}{*}{$\begin{array}{l}\text { Wisconsin } \\
\text { unique } \\
\text { well number }\end{array}$} & \multirow{2}{*}{$\begin{array}{c}\text { DNR } \\
\text { permit } \\
\text { number }\end{array}$} & \multirow[b]{2}{*}{ County } & \multirow[b]{2}{*}{ Well type } \\
\hline Layer & Row & Column & $\begin{array}{l}\text { Million } \\
\text { gallons } \\
\text { per year }\end{array}$ & $\begin{array}{l}\text { Million } \\
\text { gallons } \\
\text { per day }\end{array}$ & & & & \\
\hline 1 & 458 & 123 & 11.8 & 0.032 & -- & 2183 & Pierce & Agricultural \\
\hline 1 & 460 & 126 & 11.8 & .032 & -- & 2184 & Pierce & Agricultural \\
\hline 1 & 424 & 108 & 11.8 & .032 & BC644 & 23001 & Pierce & Agricultural \\
\hline 1 & 475 & 183 & 11.8 & .032 & BC646 & 23004 & Pierce & Agricultural \\
\hline 1 & 401 & 115 & 6.26 & .017 & BC647 & 23005 & Pierce & Agricultural \\
\hline 1 & 400 & 150 & 12.2 & .033 & ВC649 & 23007 & Pierce & Agricultural \\
\hline $1,2,3,4$ & 498 & 169 & 26.3 & .072 & BC650 & 23008 & Pierce & Agricultural \\
\hline 1 & 491 & 152 & 13.7 & .037 & -- & 23009 & Pierce & Agricultural \\
\hline 1 & 429 & 103 & 11.8 & .032 & CG740 & 23011 & Pierce & Agricultural \\
\hline 1 & 407 & 110 & 11.8 & .032 & GV421 & 23012 & Pierce & Agricultural \\
\hline 4 & 512 & 217 & 9.40 & .026 & KQ768 & 2942 & Pierce & Industrial \\
\hline 1 & 494 & 161 & 27.1 & .074 & BE783 & 57603 & Pierce & Commercial or industrial \\
\hline 1,2 & 499 & 189 & 27.8 & .076 & BE790 & 57610 & Pierce & Commercial or industrial \\
\hline $1,2,3$ & 407 & 110 & 11.8 & .032 & AK760 & 794 & Pierce & Agricultural \\
\hline $1,2,3$ & 440 & 175 & 2.57 & .077 & BP847 & -- & Pierce & Commercial or industrial \\
\hline 1 & 431 & 97 & 0.53 & .001 & BP849 & -- & Pierce & Commercial or industrial \\
\hline 1 & 431 & 95 & 6.07 & .017 & KQ771 & -- & Pierce & Commercial or industrial \\
\hline $1,2,3,4$ & 104 & 189 & 9.40 & .026 & MJ324 & 2075 & Polk & Commercial or industrial \\
\hline 1 & 197 & 259 & 9.40 & .026 & -- & 2119 & Polk & Commercial or industrial \\
\hline 1 & 195 & 259 & 9.40 & .026 & -- & 2120 & Polk & Commercial or industrial \\
\hline 1 & 195 & 259 & 9.40 & .026 & MJ302 & 2120 & Polk & Commercial or industrial \\
\hline 1 & 272 & 237 & 4.90 & .013 & BC652 & 23302 & Polk & Agricultural \\
\hline 1 & 224 & 241 & 11.8 & .032 & BC653 & 23303 & Polk & Agricultural \\
\hline $1,2,3,4$ & 233 & 139 & 9.67 & .026 & BC654 & 23305 & Polk & Agricultural \\
\hline 1 & 269 & 189 & 11.8 & .032 & BC655 & 23306 & Polk & Agricultural \\
\hline $1,2,3,4$ & 227 & 151 & 6.21 & .017 & BC656 & 23307 & Polk & Agricultural \\
\hline $1,2,3,4$ & 265 & 148 & 11.6 & .032 & BC657 & 23308 & Polk & Agricultural \\
\hline $1,2,3,4$ & 225 & 138 & 15.1 & .041 & BC659 & 23310 & Polk & Agricultural \\
\hline 1 & 230 & 238 & 11.8 & .032 & BC660 & 23313 & Polk & Agricultural \\
\hline 1 & 183 & 233 & 11.8 & .032 & BC661 & 23314 & Polk & Agricultural \\
\hline 1,2 & 259 & 201 & 21.6 & .059 & BC662 & 23315 & Polk & Agricultural \\
\hline 1 & 241 & 211 & 11.8 & .032 & -- & 23316 & Polk & Agricultural \\
\hline $1,2,3,4$ & 178 & 190 & 11.8 & .032 & JB268 & 23317 & Polk & Agricultural \\
\hline $1,2,3,4$ & 225 & 171 & 9.40 & .026 & RI534 & 3918 & Polk & Commercial or industrial \\
\hline $1,2,3,4$ & 224 & 139 & 0.40 & .001 & BE791 & 58001 & Polk & Commercial or industrial \\
\hline 1 & 231 & 264 & 100 & .27 & BE794 & 58004 & Polk & Commercial or industrial \\
\hline $1,2,3,4$ & 104 & 189 & 9.71 & .027 & BE795 & 58005 & Polk & Commercial or industrial \\
\hline 1 & 208 & 226 & 10.7 & .029 & BE796 & 58006 & Polk & Commercial or industrial \\
\hline
\end{tabular}


Appendix 2. Groundwater withdrawals from agricultural, commercial, and industrial wells in the regional groundwaterflow model.-Continued

[DNR, Wisconsin Department of Natural Resources]

\begin{tabular}{|c|c|c|c|c|c|c|c|c|}
\hline \multicolumn{3}{|c|}{ Location in model } & \multicolumn{2}{|c|}{$\begin{array}{c}\text { Estimated average } \\
\text { pumping rate, 1978-89 }\end{array}$} & \multirow{2}{*}{$\begin{array}{l}\text { Wisconsin } \\
\text { unique } \\
\text { well number }\end{array}$} & \multirow{2}{*}{$\begin{array}{c}\text { DNR } \\
\text { permit } \\
\text { number }\end{array}$} & \multirow[b]{2}{*}{ County } & \multirow[b]{2}{*}{ Well type } \\
\hline Layer & Row & Column & $\begin{array}{l}\text { Million } \\
\text { gallons } \\
\text { per year }\end{array}$ & $\begin{array}{l}\text { Million } \\
\text { gallons } \\
\text { per day }\end{array}$ & & & & \\
\hline $1,2,3,4$ & 224 & 173 & 56.0 & 0.153 & EL386 & 738 & Polk & Commercial or industrial \\
\hline 1,2 & 329 & 151 & 11.8 & .032 & -- & 1036 & St. Croix & Agricultural \\
\hline 4 & 295 & 141 & 11.8 & .032 & GL670 & 1168 & St. Croix & Agricultural \\
\hline 1 & 305 & 157 & 11.8 & .032 & -- & 1845 & St. Croix & Agricultural \\
\hline 1 & 352 & 129 & 10.0 & .027 & NV202 & 2234 & St. Croix & Commercial or industrial \\
\hline 1 & 300 & 211 & 11.8 & .032 & MP038 & 2550 & St. Croix & Commercial or industrial \\
\hline 4 & 331 & 114 & 11.8 & .032 & NB168 & 2584 & St. Croix & Agricultural \\
\hline 1 & 320 & 162 & 9.40 & .026 & RQ528 & 2713 & St. Croix & Commercial or industrial \\
\hline 1 & 324 & 227 & 10.0 & .027 & LB894 & 2758 & St. Croix & Commercial or industrial \\
\hline 1 & 324 & 227 & 10.0 & .027 & LB895 & 2759 & St. Croix & Commercial or industrial \\
\hline 1 & 295 & 144 & 1.92 & .005 & BD453 & 29201 & St. Croix & Agricultural \\
\hline 1,2 & 315 & 164 & 15.2 & .042 & BD454 & 29202 & St. Croix & Agricultural \\
\hline 1,2 & 304 & 162 & 5.25 & .014 & BD455 & 29203 & St. Croix & Agricultural \\
\hline 1 & 333 & 148 & 45.0 & .12 & BD456 & 29204 & St. Croix & Agricultural \\
\hline 1 & 294 & 170 & 13.5 & .037 & BD457 & 29205 & St. Croix & Agricultural \\
\hline 1 & 293 & 148 & 11.8 & .032 & BD458 & 29206 & St. Croix & Agricultural \\
\hline 1 & 294 & 146 & 11.8 & .032 & BD459 & 29207 & St. Croix & Agricultural \\
\hline 1 & 361 & 115 & 11.9 & .032 & BD459 & 29208 & St. Croix & Agricultural \\
\hline 1 & 292 & 149 & 4.04 & .011 & BD461 & 29209 & St. Croix & Agricultural \\
\hline 1 & 395 & 226 & 1.45 & .004 & BD462 & 29210 & St. Croix & Agricultural \\
\hline 1 & 391 & 133 & 9.36 & .026 & -- & 29211 & St. Croix & Agricultural \\
\hline 1 & 352 & 259 & 11.8 & .032 & -- & 29212 & St. Croix & Agricultural \\
\hline $1,2,3,4$ & 326 & 132 & 18.1 & .049 & BD466 & 29214 & St. Croix & Agricultural \\
\hline 1 & 392 & 146 & 6.28 & .017 & BD468 & 29216 & St. Croix & Agricultural \\
\hline 1 & 384 & 144 & 18.2 & .050 & BD469 & 29217 & St. Croix & Agricultural \\
\hline 1 & 396 & 120 & 4.50 & .012 & BD471 & 29219 & St. Croix & Agricultural \\
\hline 1 & 385 & 152 & 0.48 & .001 & BD472 & 29220 & St. Croix & Agricultural \\
\hline 1,2 & 296 & 192 & 13.5 & .037 & BD477 & 29226 & St. Croix & Agricultural \\
\hline 1 & 352 & 182 & 19.5 & .053 & BD478 & 29228 & St. Croix & Agricultural \\
\hline $1,2,3$ & 283 & 172 & 25.2 & .069 & BD479 & 29230 & St. Croix & Agricultural \\
\hline 1 & 322 & 181 & 2.80 & .008 & BD481 & 29232 & St. Croix & Agricultural \\
\hline $1,2,3$ & 324 & 181 & 10.3 & .028 & BD482 & 29233 & St. Croix & Agricultural \\
\hline 1 & 363 & 167 & 6.13 & .017 & BD483 & 29234 & St. Croix & Agricultural \\
\hline 1,2 & 321 & 206 & 8.45 & .023 & BD485 & 29237 & St. Croix & Agricultural \\
\hline 1,2 & 324 & 206 & 8.20 & .022 & BD486 & 29238 & St. Croix & Agricultural \\
\hline 1 & 299 & 183 & 20.4 & .056 & BD487 & 29239 & St. Croix & Agricultural \\
\hline 1 & 383 & 175 & 5.40 & .015 & BD488 & 29240 & St. Croix & Agricultural \\
\hline 1 & 349 & 158 & 18.0 & .049 & BD489 & 29241 & St. Croix & Agricultural \\
\hline
\end{tabular}


Appendix 2. Groundwater withdrawals from agricultural, commercial, and industrial wells in the regional groundwaterflow model.-Continued

[DNR, Wisconsin Department of Natural Resources]

\begin{tabular}{|c|c|c|c|c|c|c|c|c|}
\hline \multicolumn{3}{|c|}{ Location in model } & \multicolumn{2}{|c|}{$\begin{array}{c}\text { Estimated average } \\
\text { pumping rate, 1978-89 }\end{array}$} & \multirow{2}{*}{$\begin{array}{l}\text { Wisconsin } \\
\text { unique } \\
\text { well number }\end{array}$} & \multirow{2}{*}{$\begin{array}{c}\text { DNR } \\
\text { permit } \\
\text { number }\end{array}$} & \multirow[b]{2}{*}{ County } & \multirow[b]{2}{*}{ Well type } \\
\hline Layer & Row & Column & $\begin{array}{l}\text { Million } \\
\text { gallons } \\
\text { per year }\end{array}$ & $\begin{array}{l}\text { Million } \\
\text { gallons } \\
\text { per day }\end{array}$ & & & & \\
\hline 1 & 336 & 166 & 8.14 & 0.022 & BD490 & 29242 & St. Croix & Agricultural \\
\hline 1,2 & 284 & 169 & 14.2 & .039 & BD491 & 29243 & St. Croix & Agricultural \\
\hline 1 & 365 & 205 & 16.7 & .046 & BD492 & 29244 & St. Croix & Agricultural \\
\hline 1 & 384 & 202 & 16.3 & .045 & BD493 & 29245 & St. Croix & Agricultural \\
\hline 1 & 374 & 169 & 8.43 & .023 & BD494 & 29247 & St. Croix & Agricultural \\
\hline 1 & 370 & 163 & 5.03 & .014 & BD496 & 29251 & St. Croix & Agricultural \\
\hline 1 & 342 & 173 & 10.5 & .029 & BD499 & 29259 & St. Croix & Agricultural \\
\hline 1 & 350 & 171 & 13.3 & .036 & BD500 & 29260 & St. Croix & Agricultural \\
\hline 1 & 323 & 143 & 18.6 & .051 & BD501 & 29261 & St. Croix & Agricultural \\
\hline $1,2,3$ & 323 & 131 & 10.0 & .027 & BD503 & 29267 & St. Croix & Agricultural \\
\hline 1 & 319 & 173 & 17.3 & .047 & BD504 & 29269 & St. Croix & Agricultural \\
\hline 1 & 320 & 166 & 3.67 & .010 & BD505 & 29270 & St. Croix & Agricultural \\
\hline 1,2 & 312 & 166 & 26.8 & .073 & BD507 & 29272 & St. Croix & Agricultural \\
\hline 1 & 315 & 162 & 20.9 & .057 & BD508 & 29273 & St. Croix & Agricultural \\
\hline 1,2 & 312 & 176 & 10.3 & .028 & BD509 & 29274 & St. Croix & Agricultural \\
\hline 1 & 291 & 163 & 11.8 & .032 & BD511 & 29277 & St. Croix & Agricultural \\
\hline 1 & 328 & 187 & 5.76 & .016 & BD512 & 29278 & St. Croix & Agricultural \\
\hline 1 & 344 & 166 & 11.8 & .032 & BD513 & 29279 & St. Croix & Agricultural \\
\hline 1 & 340 & 165 & 11.8 & .032 & BD514 & 29280 & St. Croix & Agricultural \\
\hline 1,2 & 285 & 174 & 10.5 & .029 & BD515 & 29281 & St. Croix & Agricultural \\
\hline 1 & 363 & 160 & 9.40 & .026 & NA628 & 3307 & St. Croix & Commercial or industrial \\
\hline 1 & 346 & 188 & 11.8 & .032 & -- & 3764 & St. Croix & Agricultural \\
\hline 1 & 379 & 253 & 14.0 & .038 & CG786 & 381 & St. Croix & Commercial or industrial \\
\hline 1 & 325 & 227 & 10.0 & .027 & LE637 & 3892 & St. Croix & Commercial or industrial \\
\hline 1 & 364 & 209 & 12.4 & .034 & BE889 & 60801 & St. Croix & Agricultural \\
\hline 1 & 364 & 209 & 93.0 & .26 & BE890 & 60802 & St. Croix & Commercial or industrial \\
\hline 1 & 378 & 253 & 24.4 & .067 & BE891 & 60804 & St. Croix & Commercial or industrial \\
\hline 1 & 354 & 159 & 13.7 & .038 & BE892 & 60805 & St. Croix & Commercial or industrial \\
\hline $1,2,3,4$ & 350 & 121 & 1.09 & .003 & BE893 & 60806 & St. Croix & Commercial or industrial \\
\hline 1 & 352 & 129 & 63.0 & .17 & BE896 & 60809 & St. Croix & Commercial or industrial \\
\hline 1 & 364 & 113 & 10.0 & .027 & -- & 60812 & St. Croix & Commercial or industrial \\
\hline 1,2 & 280 & 193 & 9.40 & .026 & QW432 & 67281 & St. Croix & Commercial or industrial \\
\hline 1 & 365 & 161 & 9.40 & .026 & -- & 67827 & St. Croix & Commercial or industrial \\
\hline 1 & 311 & 164 & 10.0 & .027 & -- & 85616 & St. Croix & Commercial or industrial \\
\hline 1 & 311 & 165 & 10.0 & .027 & -- & 85617 & St. Croix & Commercial or industrial \\
\hline
\end{tabular}




\section{Prepared by:}

USGS Publishing Network

Raleigh Publishing Service Center

For additional information regarding this publication, contact: USGS Wisconsin Water Science Center

8505 Research Way

Middleton, WI 53562

phone: 608-828-9901

Or visit the Wisconsin Water Science Center Web site at: http://wi.water.usgs.gov/

This publication is available online at http://pubs.usgs.gov/sir/2009/5056/. 
